\title{
Medical tourism: Reasons for choosing Iran
}

\author{
Ali Mohammad Mosadeghrad ${ }^{1}$, Mehregan Sadeghi ${ }^{2 *}$ \\ 1. Health Information Management Research Center, School of Public Health, Tehran University of Medical Sciences, Tehran, Iran \\ 2. School of Public Health, Tehran University of Medical Sciences, Tehran, Iran
}

Received: 1 December 2020

Accepted for publication: 11 April 2021

[EPub a head of print-14 April 2021]

Payesh: 2021; 20 (2):145-166

\begin{abstract}
Objective(s): Medical tourism is the process of traveling to another country for the purpose of promoting, restoring, and maintaining health along with recreation and pleasure. Iran has a high potential to attract medical tourists due to its special geographical location, abundant natural resources and quality and cheap medical services. The aim of this study was to identify reasons for choosing Iran by medical tourists to receive medical services.

Methods: This qualitative study was conducted in 2020 using semi-structured interviews with 18 medical tourists and 23 physicians, nurses and medical tourism experts (Pluralistic evaluations) in Tehran city, Iran. Thematic analysis method was used to analyse data.

Results: In this study, overall 22 reasons for choosing Iran to receive medical services were identified, which were divided into seven groups: type of service (type and severity of illness and availability and comprehensiveness of service), quality of service (specialized and committed physicians and staff, advanced equipment, amenities, fast and easy service delivery process and effective result), service cost (medical service tariff and health insurance coverage), patient previous experience, advertising (hospital and tourism company advertising, word of mouth, and the internet), contextual factors (cultural affinity, tourist attractions, and political climate) and patient socio-economic factors. Finally, a conceptual model of medical tourists' reasons for choosing Iran to receive medical services was designed. Health tourists who evaluate the value of a country's medical services well, choose that country, and if they are satisfied with the services, they come again or recommend it to others.

Conclusion: Advanced, high quality and cheap medical services are the three main reasons for choosing Iran by medical tourists. However, Iran faces some challenges in utilizing its health tourism capacities. Politicians and health system policymakers should strengthen the country's health tourism industry by analysing its strengths, weaknesses, opportunities and threats and formulating and implementing a strategic plan.
\end{abstract}

Key Words: Medical Tourism, medical tourist, patient choice, Iran

\footnotetext{
* Corresponding author: School of Public Health, Tehran University of Medical Sciences, Tehran, Iran

E-mail: Sadeghi.m@alumnus.tums.ac.ir
} 


\title{
كردشكرى يزشكى: علل انتخاب ايران
}

\author{
على محمد مصدق راد'، مهركًان صادقى \\ ا. مركز تحقيقـات مديريـت اطلاعات سـلامت، دانشكده بهداشت، دانشـعاه علـوم يزشـكى تهــــان، تهــران، ايـران

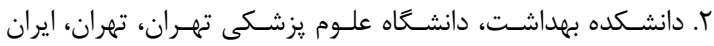 \\ تاريخ دريافت: ||

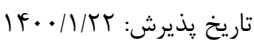

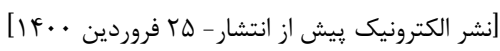

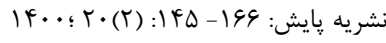

جكيده

مقدمه: گردشگرى يزشكى عبارت است از مسافرت به كشور ديخر با هدف تأمين، حفظ و ارتقاى سلامتى به همراه استراحت و تفريح. كشور ايـران

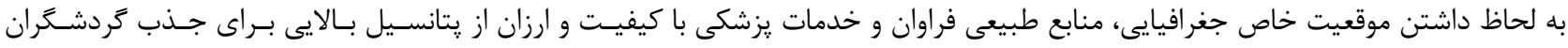

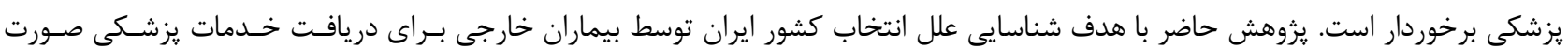

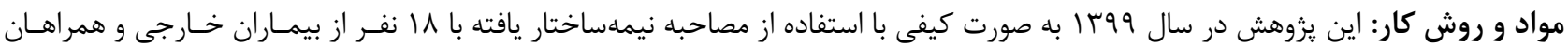

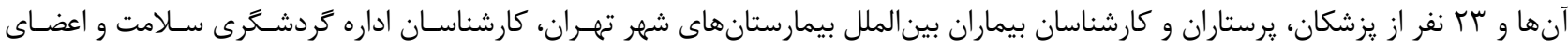

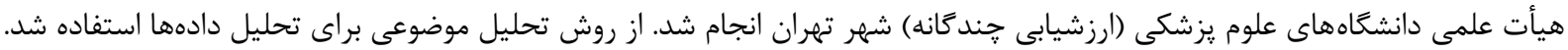

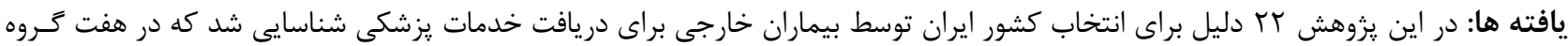

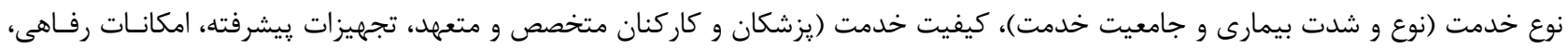

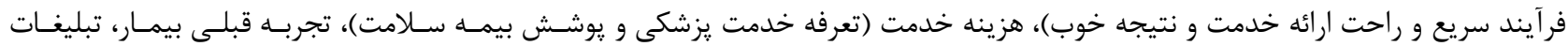

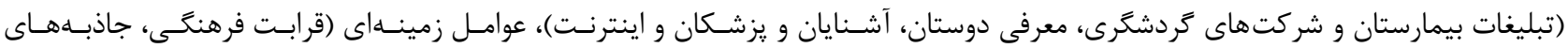

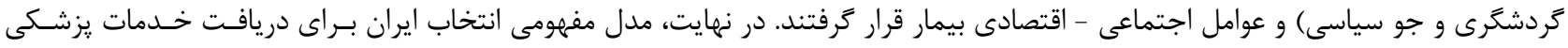

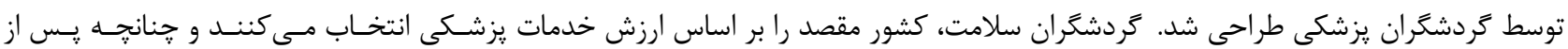

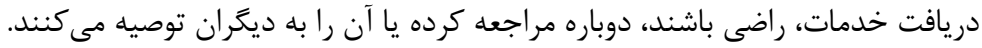

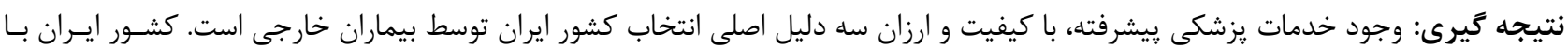

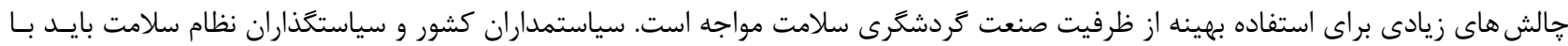

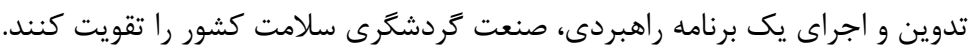

كليدوازه: كردشكرى يزشكى، بيماران خارجى، انتخاب بيمار، ايران

\section{كد اخلاق: IR.TUMS.SPH.REC1398.038}


براى افزايش توليد ناخالص داخلى، بهبود كيفيت خدمات يزشـكى و

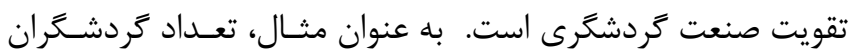

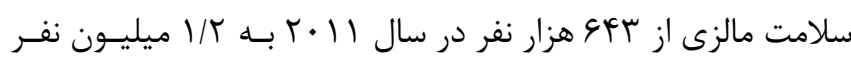

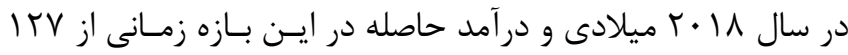

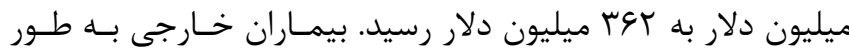

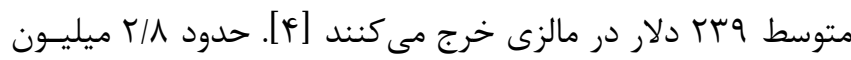

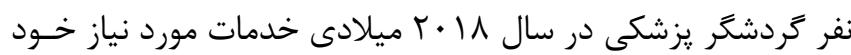

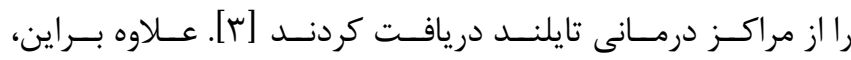

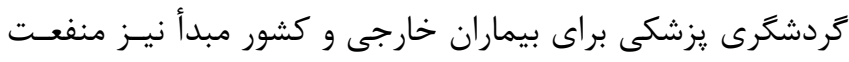

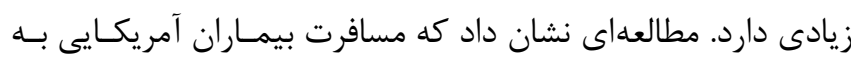

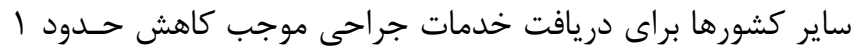

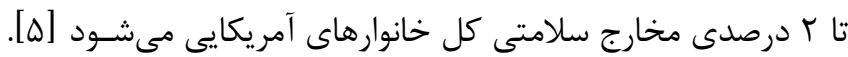

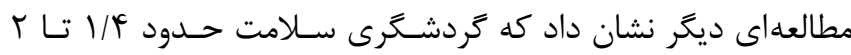

ميليارد دلار صرفهجويى در هزينههاى سلامت آمريكا دارد [ع].

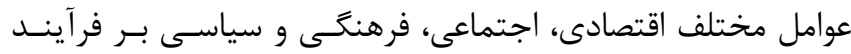

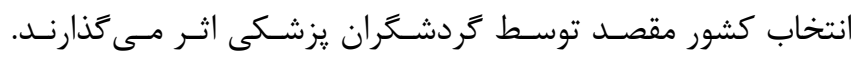

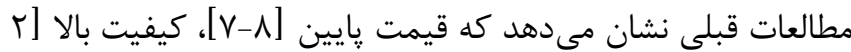

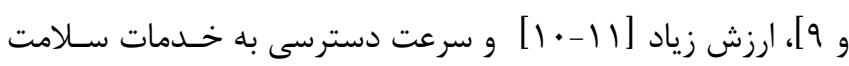

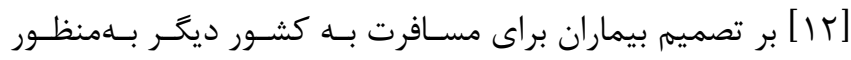

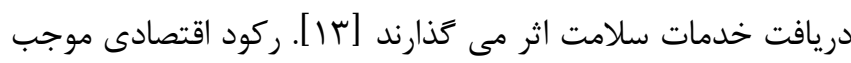

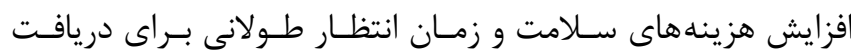
خدمات سلامت مىشود. در نتيجه، بيماران طبقه متوسط اقتصـادى لنى

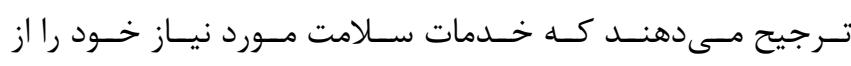
بيمارستانها و مراكز درمانى ساير كشورها دريافت كنند. حدود جهل كشور در بازار كردشكرى سلامت فعال هستند. برخى از داز

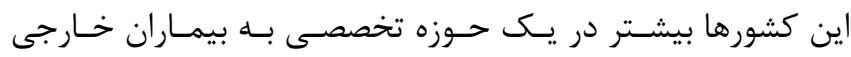

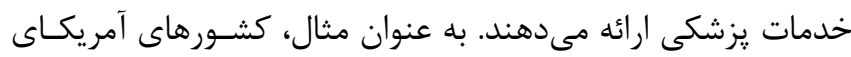

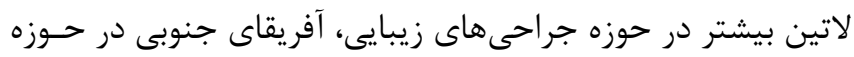

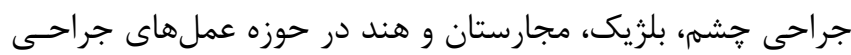

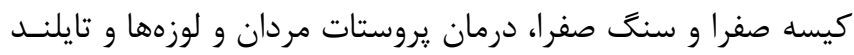

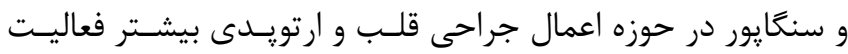

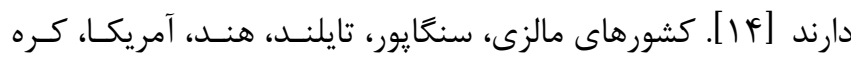

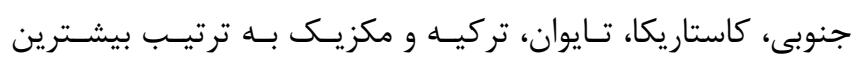

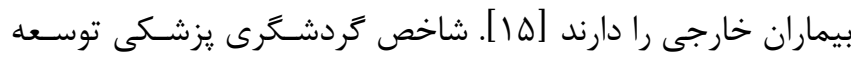

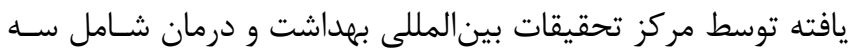

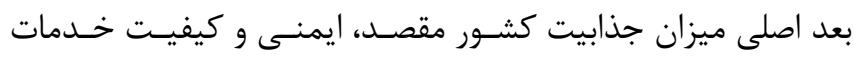

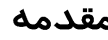

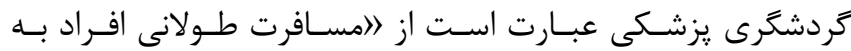

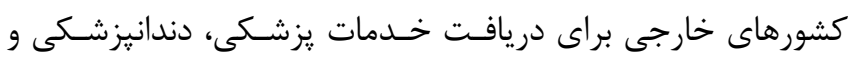

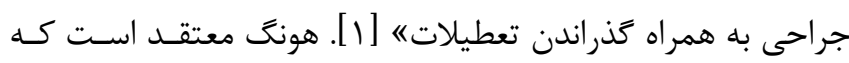
كردشكرى يزشكى به تعطيلاتى كفته مى شود كه شامل سفر بـهـ آن

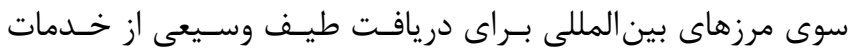

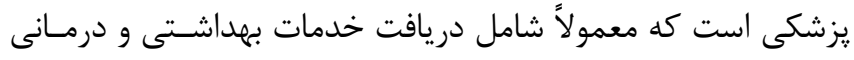

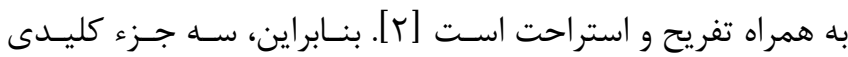
كردشكرى بزشكى عبارتند از مسافرت به كشور ديخر، با هدف اصلى تهري

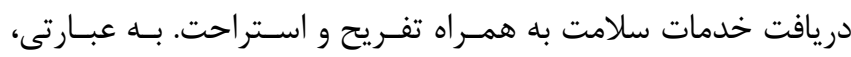

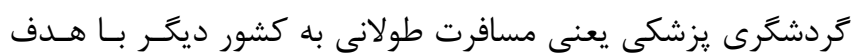

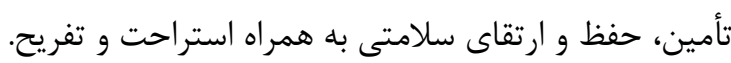

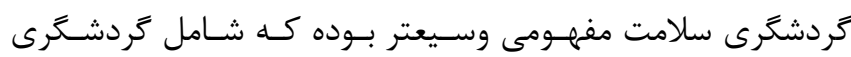

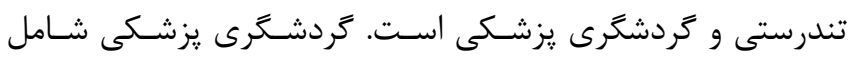
طيف وسيعى از خدمات سلامت، از خدمات ييشخيرى نظير معاينات

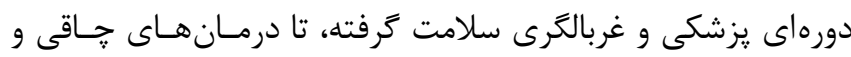

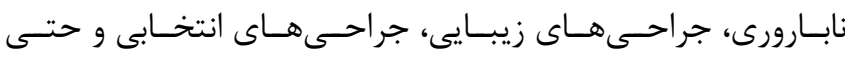

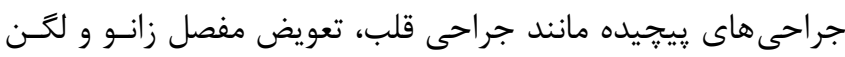

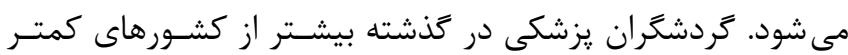

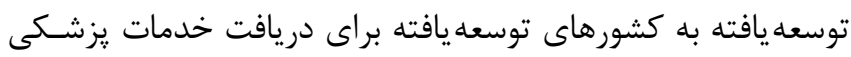

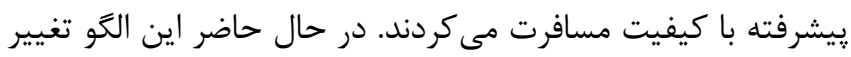

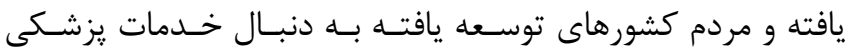

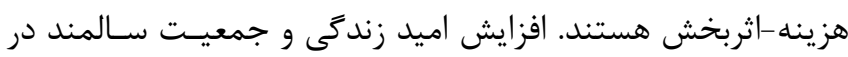

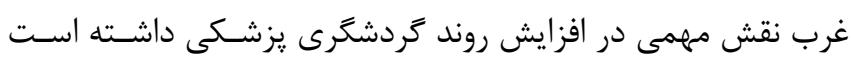

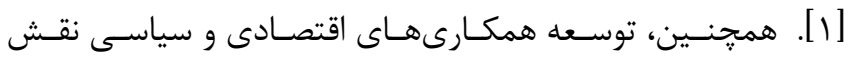

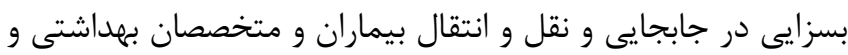

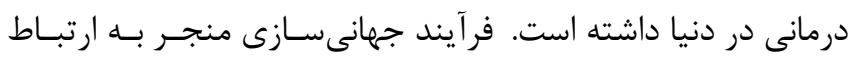

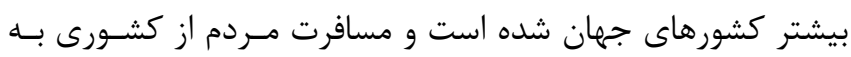
كشور ديكر سريعتر و راحتتر شده است.

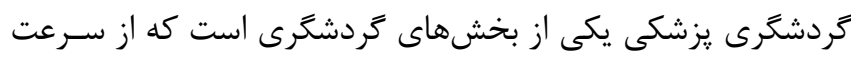

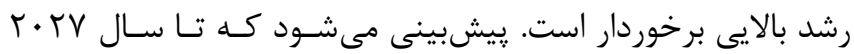

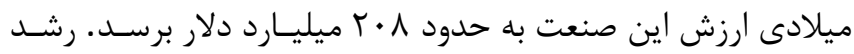

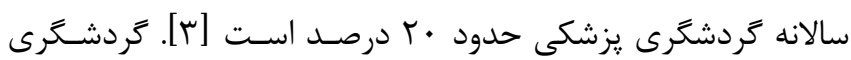

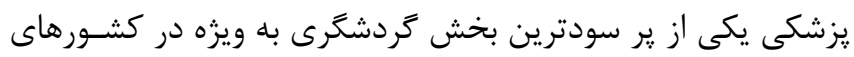

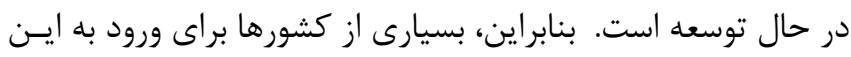

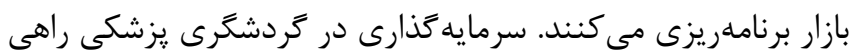




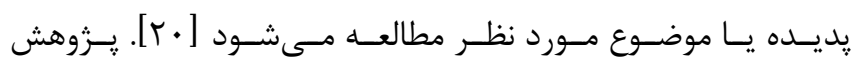

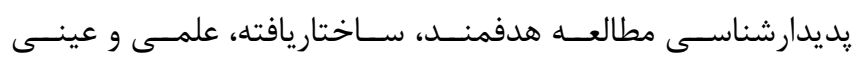

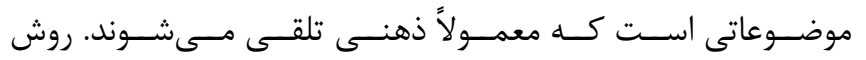

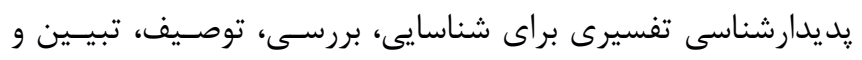

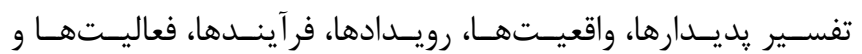
مفاهيمى كه دانش كمى در مورد آنها داريم، مناسب است.

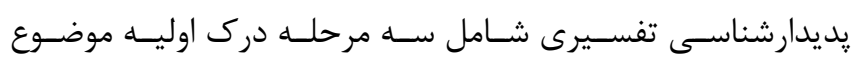

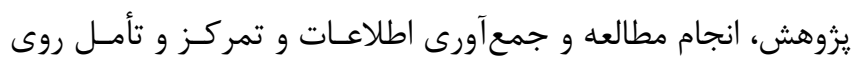

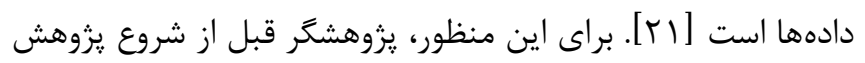

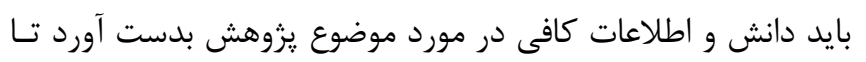

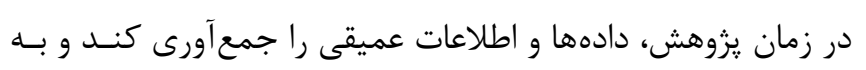

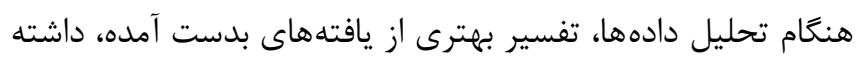

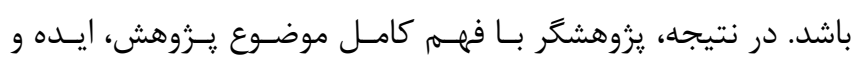

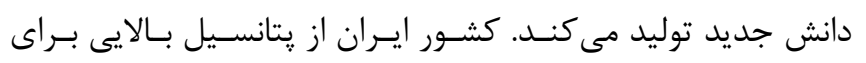

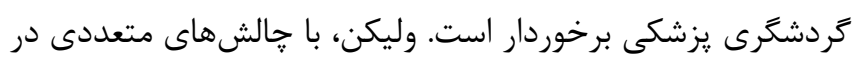

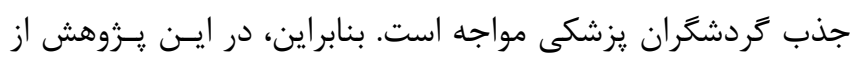

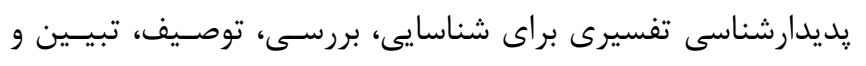

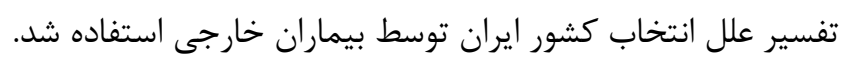

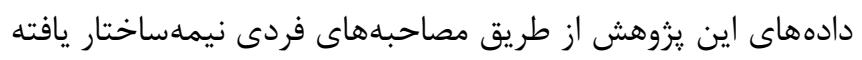

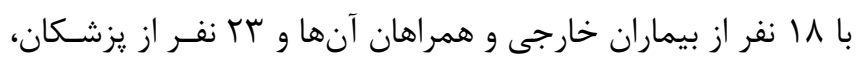

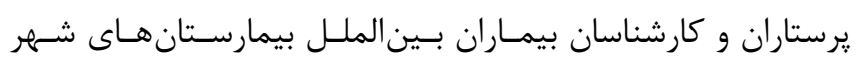

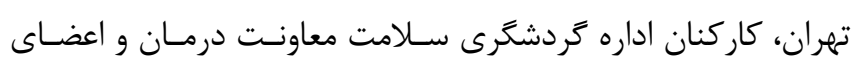

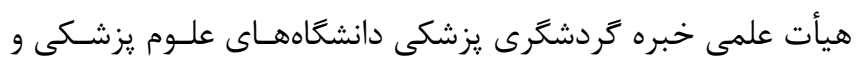

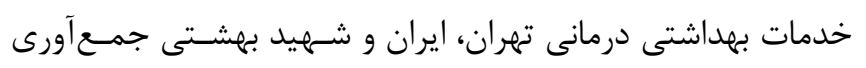

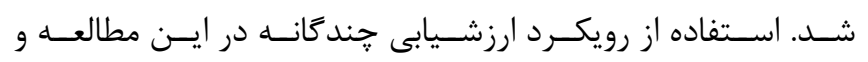

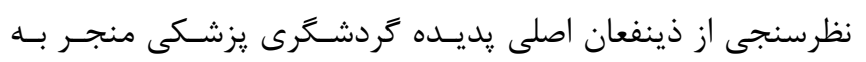

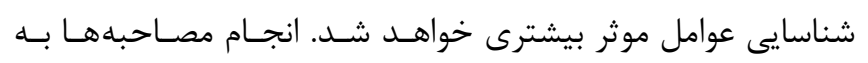

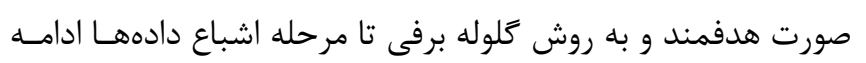

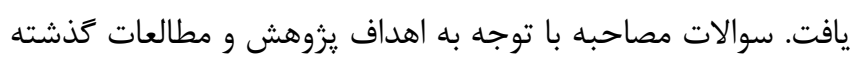

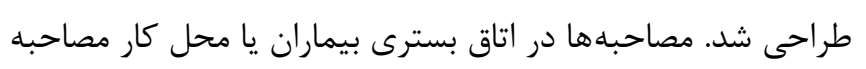

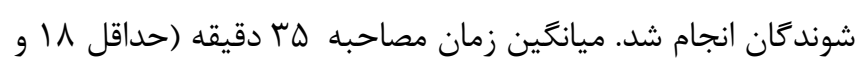

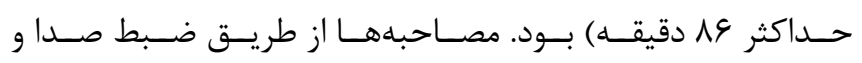

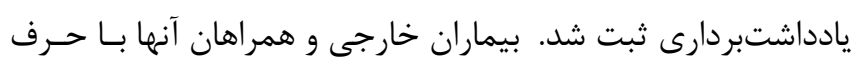

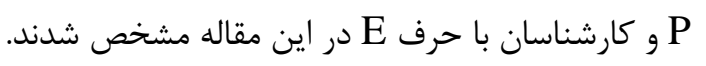

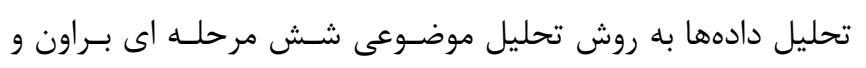

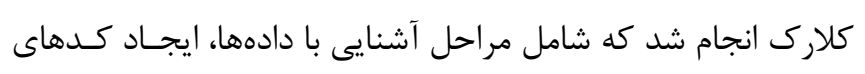

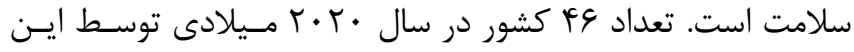

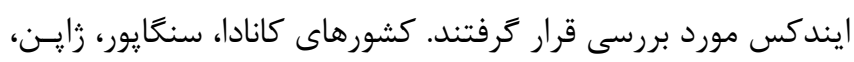

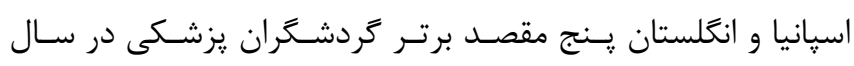

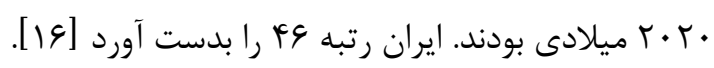

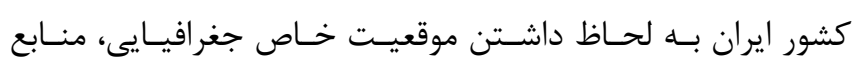

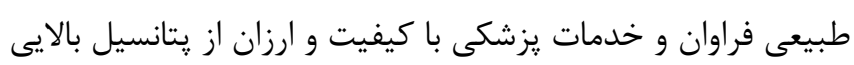

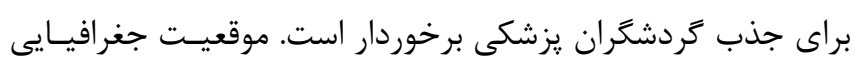

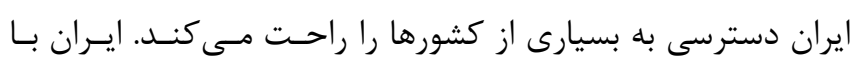

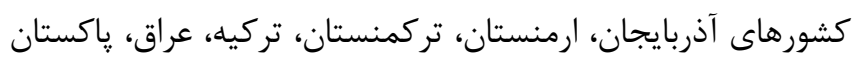

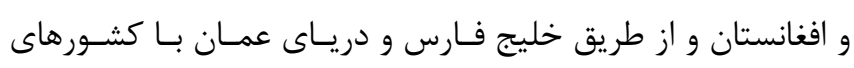

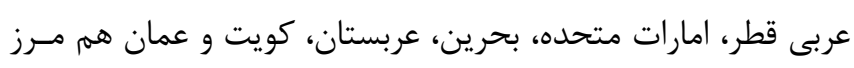

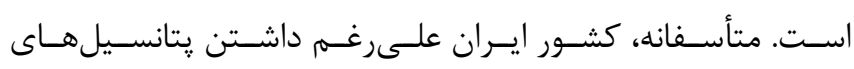

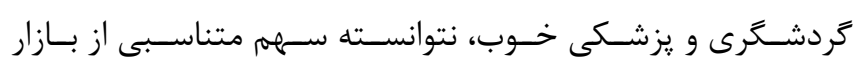

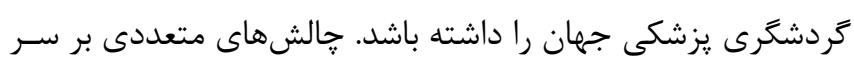

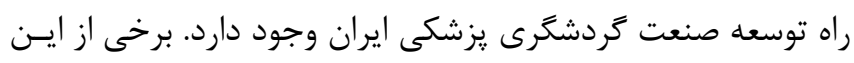

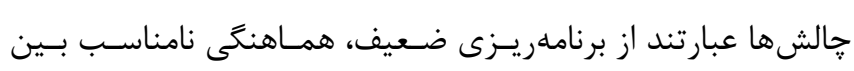

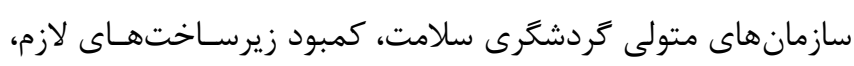

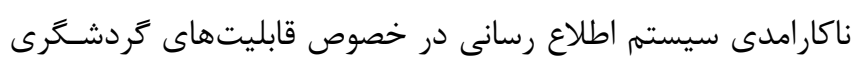

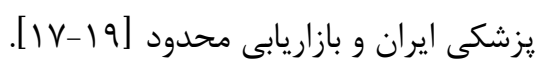

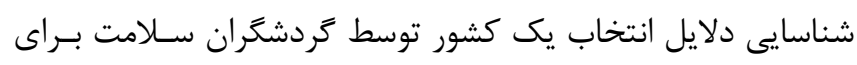

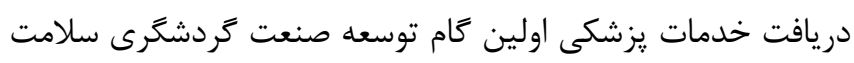

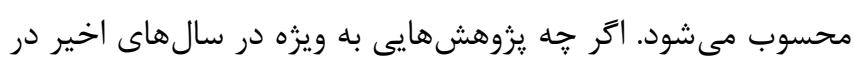

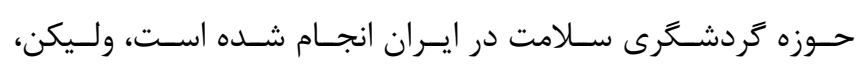

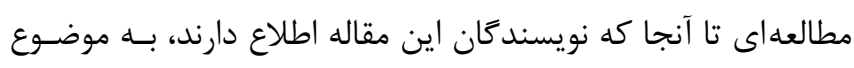

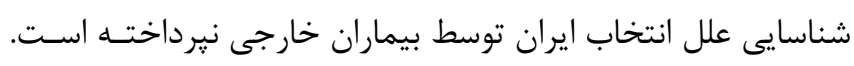

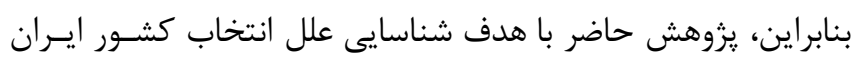

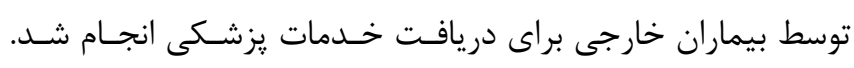

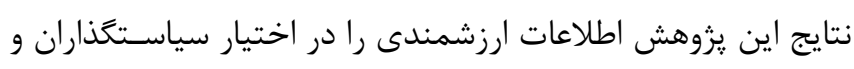

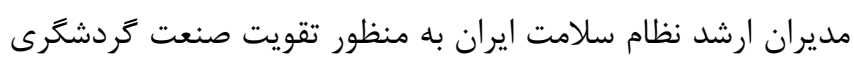
سلامت كشور قرار مىدهد.

\section{مواد و روش كار}

يزوهش كيفى حاضر به روش بديدارشناسـى تفسـيرى انجـام شـد.

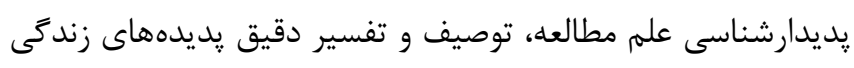

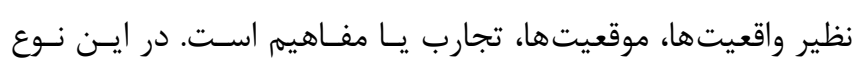

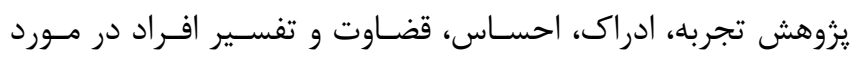


هزينه خدمت، تجربه قبلى بيمار، تبليغات، عوامل زمينهاى و عوامـل اجتماعى اقتصادى بيمار قرار كَرفتند (جدول ؟).

\section{نوع خدمت}

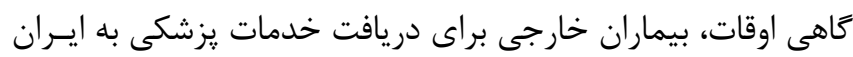

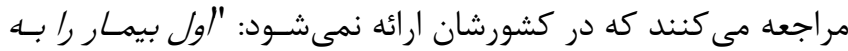

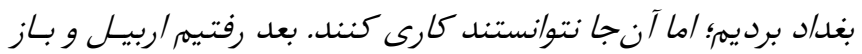

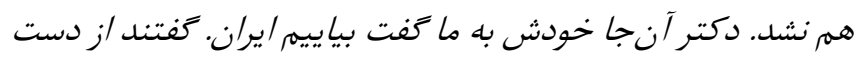

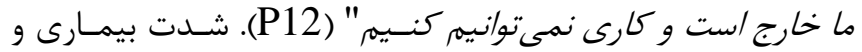

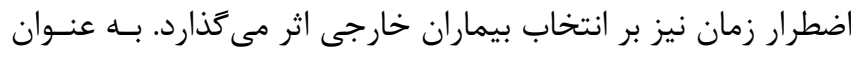

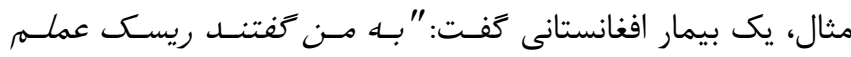

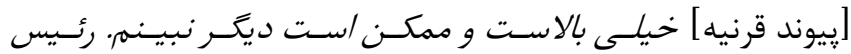
اورزانس من را معاينه كرد و كفت جون جوانى و قرنيه/ت دستكارى

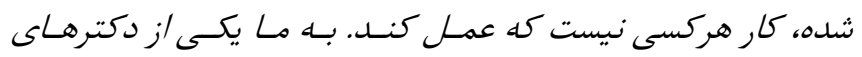
اينجا رامعرفى كرد كه /ستاد هستند" (P11).

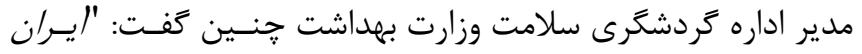

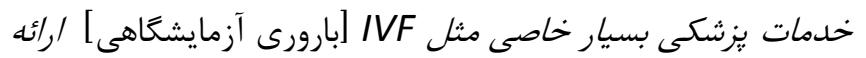

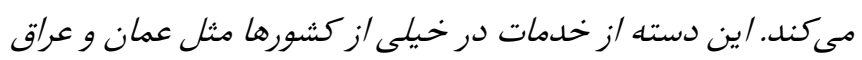
داراى محدوديتهاى قانونى /ست؛ كلا IVF و لقاح مصنوعى در / ايـن كشورها ممنوع /ست. /ين نوع /ز خدمات بزرشكى در كشور ماسكا /رائسه

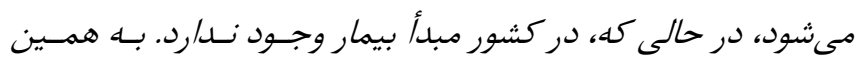

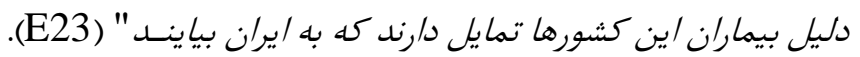

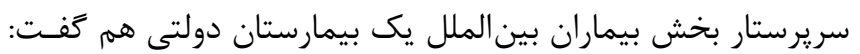

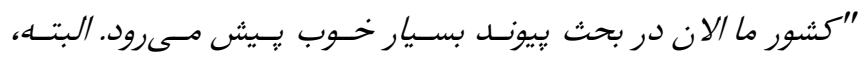

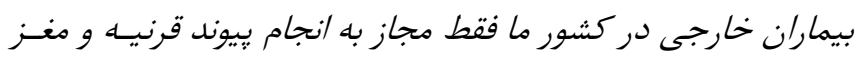

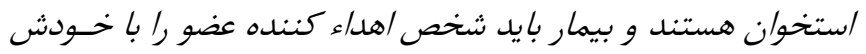

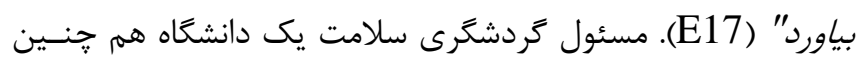

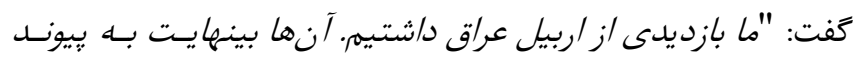

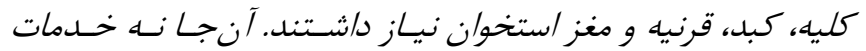

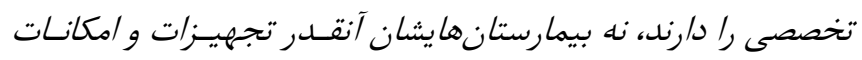

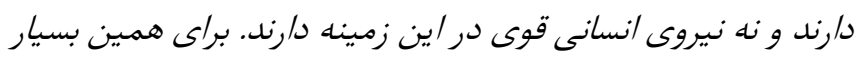

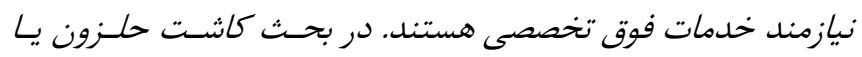

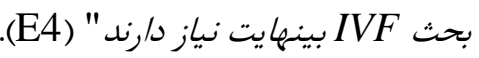

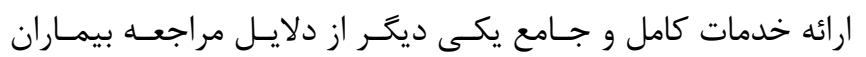

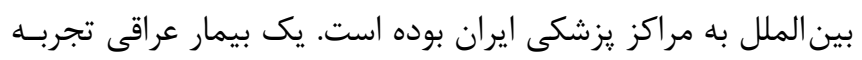

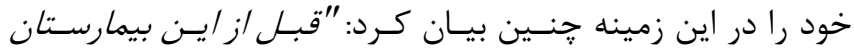

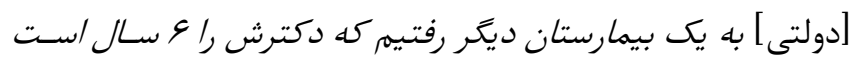

اوليه، ايجاد درون مايه هاى اوليه، مرور تمهــا، تعريـف و نـامَّـذارى

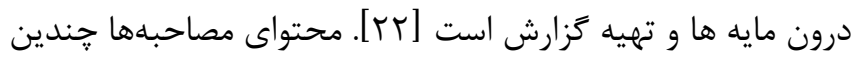

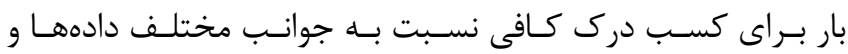

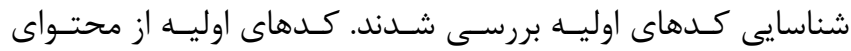
مصاحبه ها استخراج شدند. كدهاى مشابه و داراى معانى نزديـك در

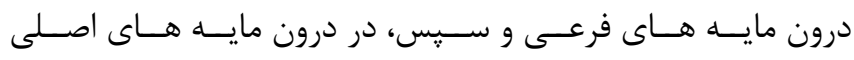

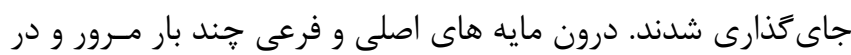

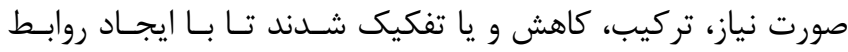

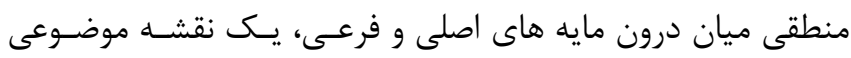

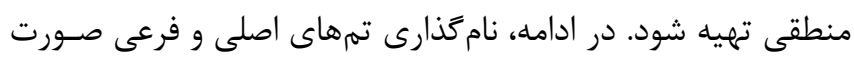

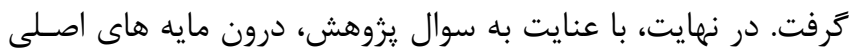

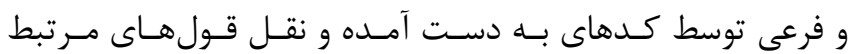

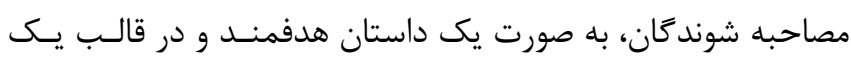

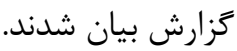
نمونه كيرى با حداكثر تنوع، انجام مصاحبه هاى بايلوت، صرف زمـان

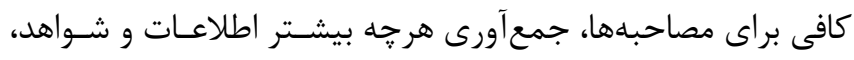

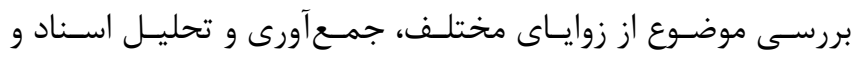
مقايسه دائم اطلاعات از جمله اقداماتى بود كه براى افـزايش اعتبـار

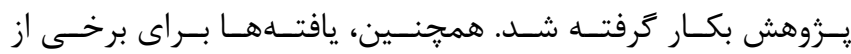

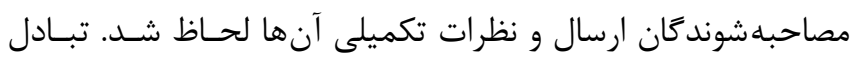

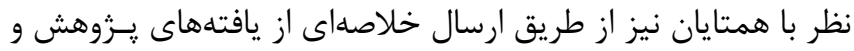

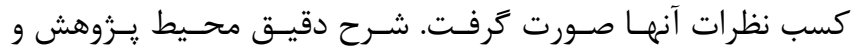

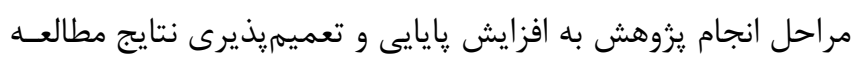
كمك نمود.

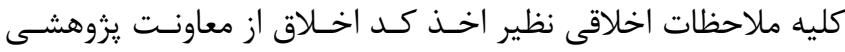

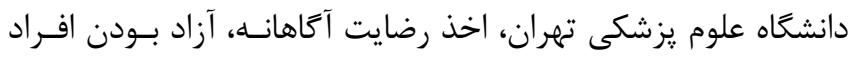
نسبت به شركت در مصاحبه، كسب اجازه براى ضبط صدا، محرمانه

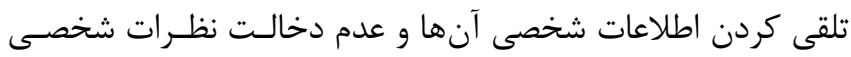

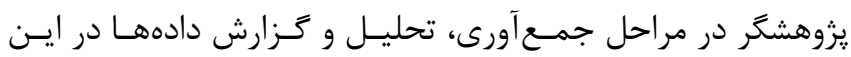
يزوهش رعايت شد.

يافتهها

اطلاعات جمعيتشناختى مصاحبهشوندكان در جدول آمدآنده است.

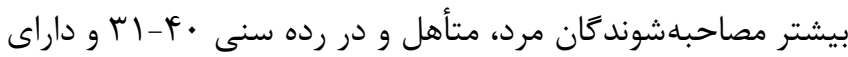

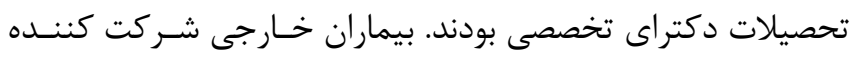

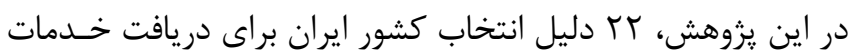

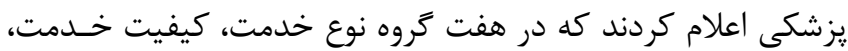


محسوب مى شود. يك بيمار آذربايجانى در اين زمينه كَفت: "/ينجا

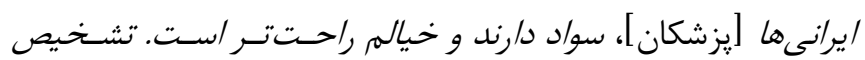

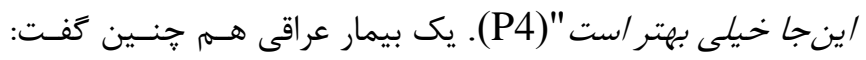

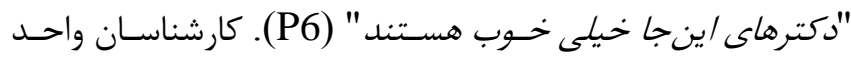

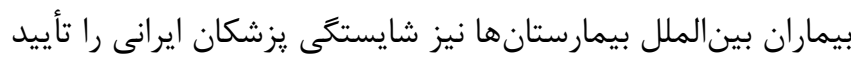

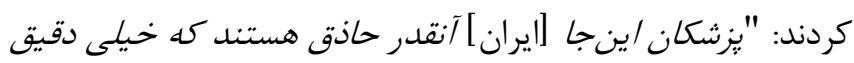

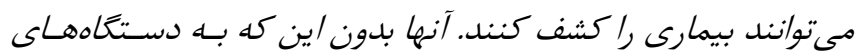
يزشكى متكى باشند، تشخيص بالينى خيلى خوبى دارنــ" (E10).

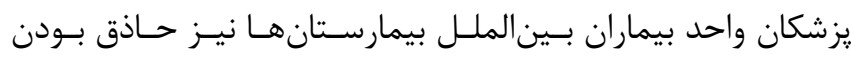

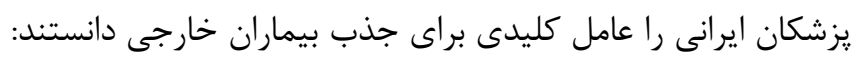

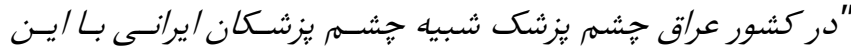

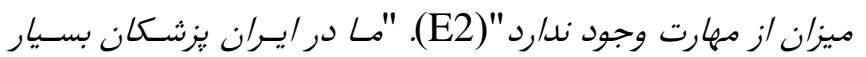

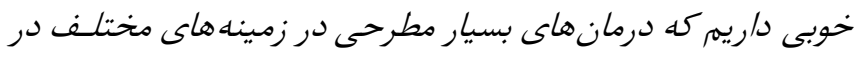

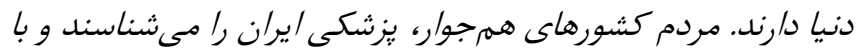

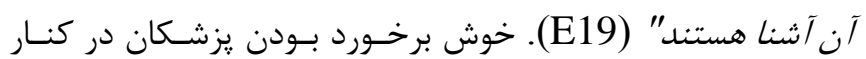

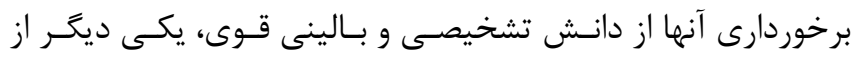

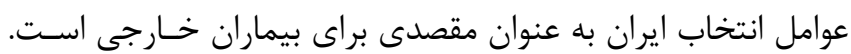

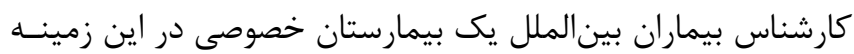

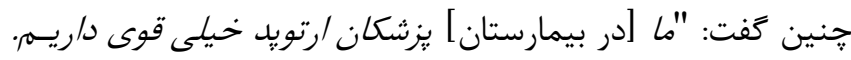

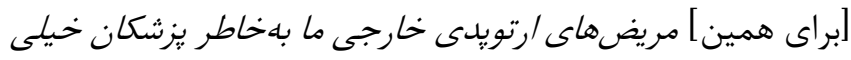

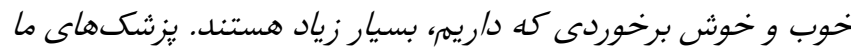

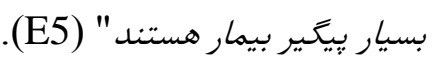

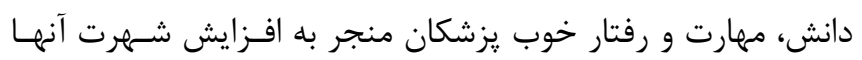
مىشود كه در جذب بيماران خارجى موثر اسـت. كارشــاس واحســ

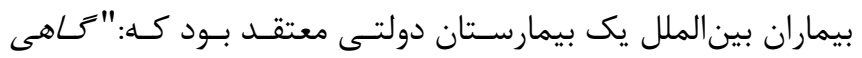

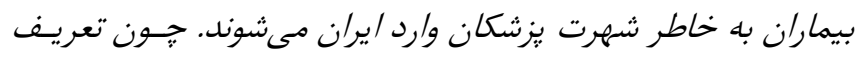

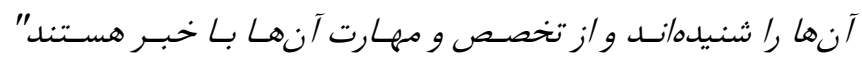

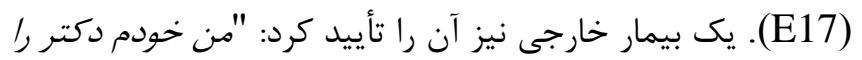

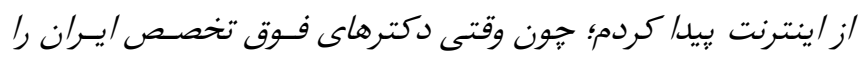

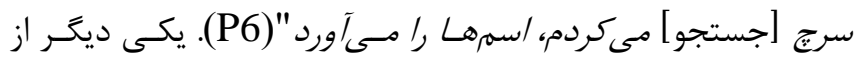

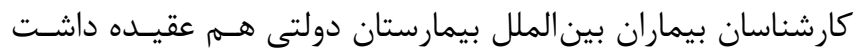

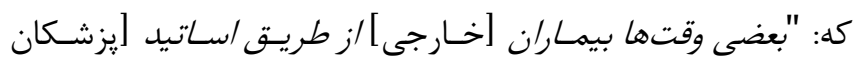

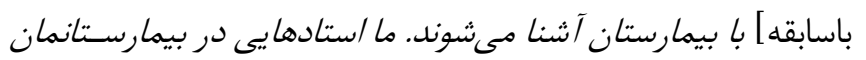
داريم كه در تخصص خود مشههور هستـند و بيمـاران خـارجى نـام

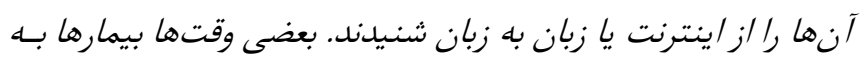

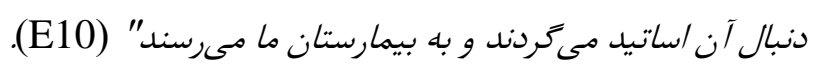

كه مىشناختيم. /و نتوانست كارى برایى ما كند و كفت بياييم/ينجا

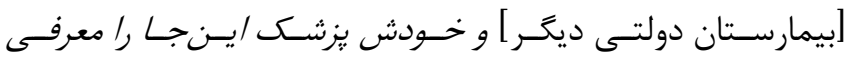

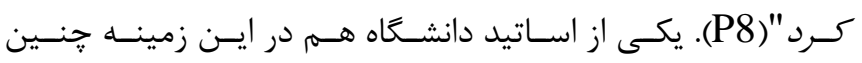

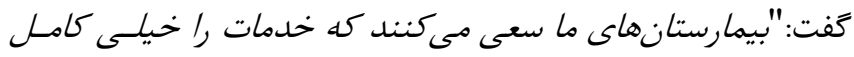

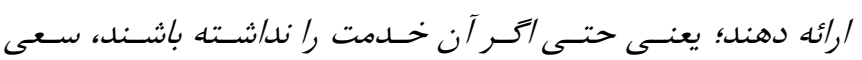

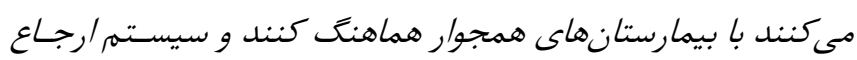
را به كار كيرند تا خدمات به طور كامل و جامع /رائه شود. خيلسى از

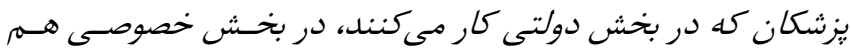

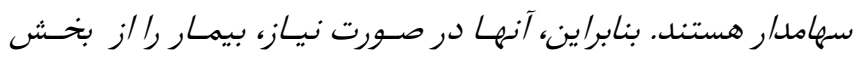
دولتى به خصوصى منتقل مىكنند" (E20). كيفيت خدمت

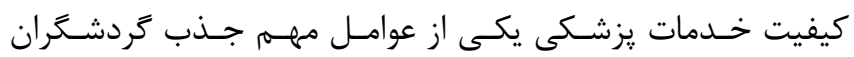

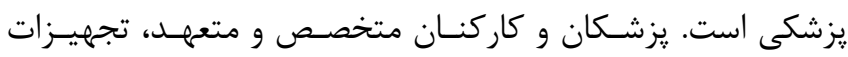

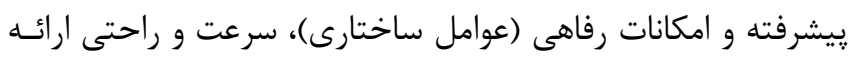
خدمت (عوامل فرآيندى) و خدمات يزشكى ممتار، ايمن و اثربخش

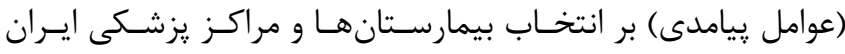

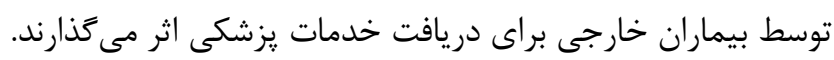

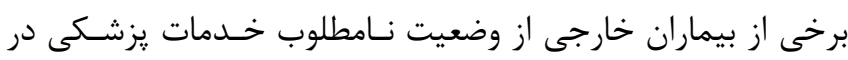

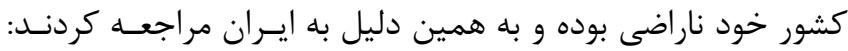

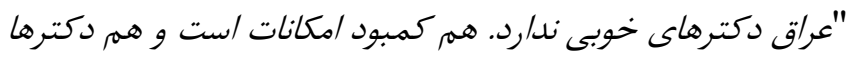

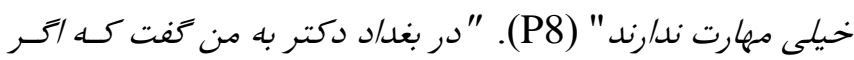

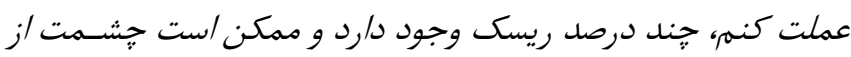

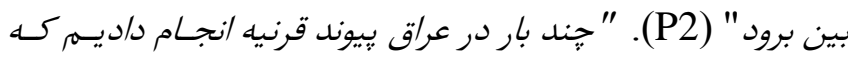

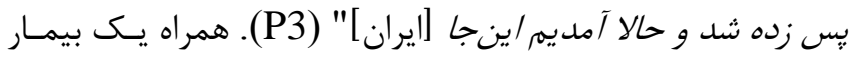

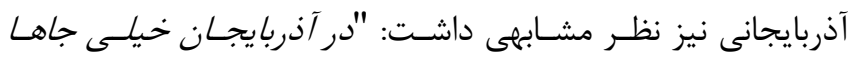

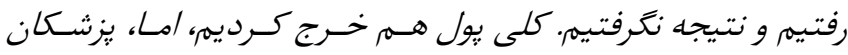

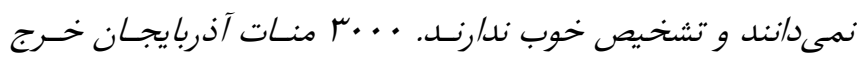

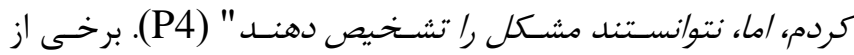

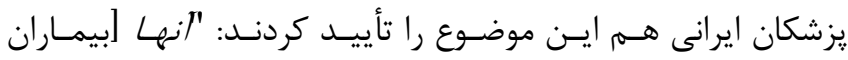

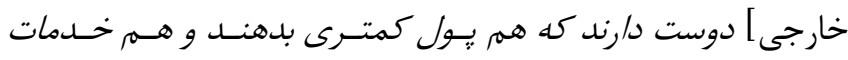

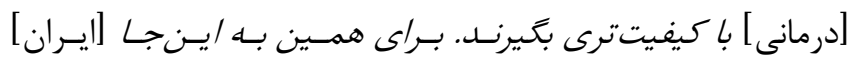

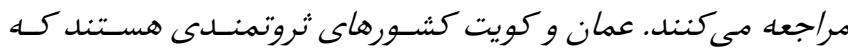

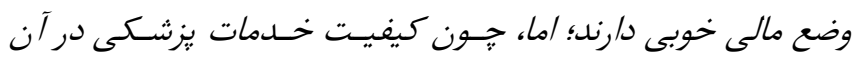
كشورها بإيين /ست، [بيماران] به / يران مي آ يند "(E2).

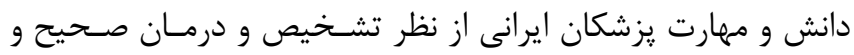

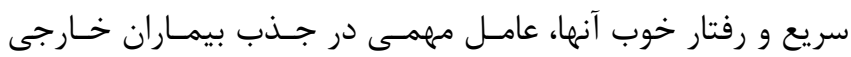


(E5)." كشورهاى همسـايه مـا از لحساظ برخـوردارى /ز تجهيـزات

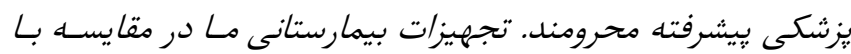
خيلى از كشورهاى منطقه بسيار بِيشرفته /ست." (E18)

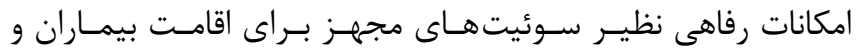

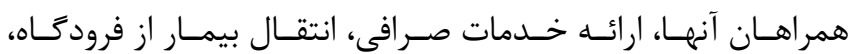

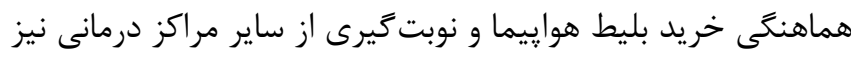

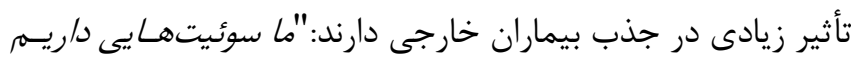

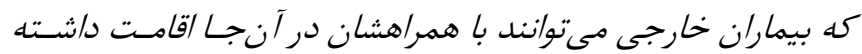

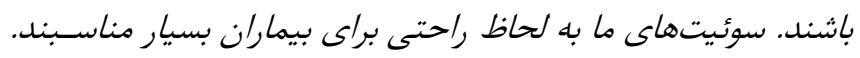

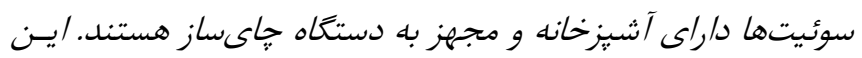

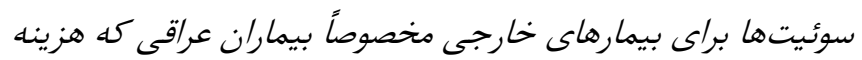

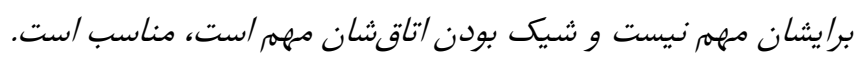

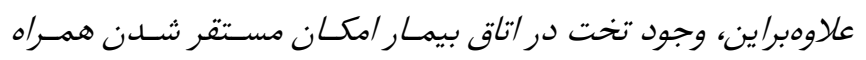

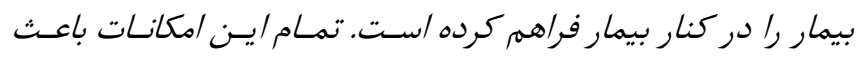

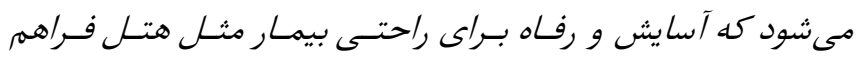

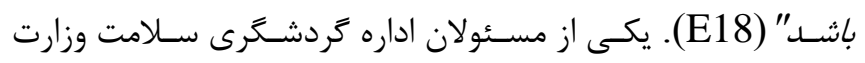

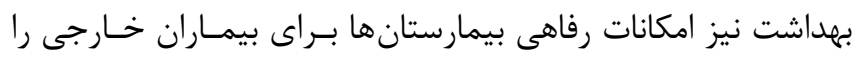

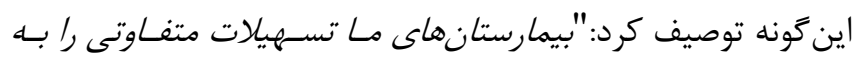

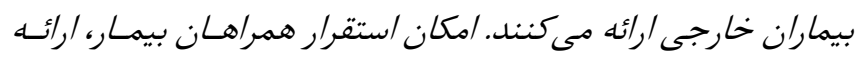

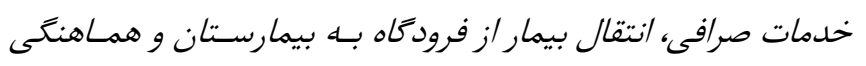

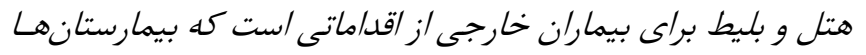

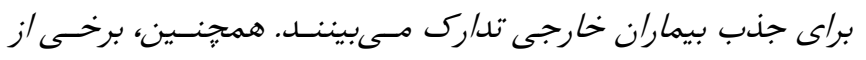

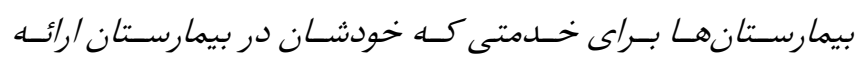

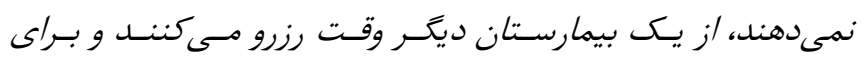

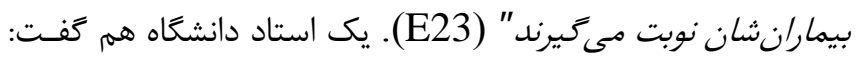

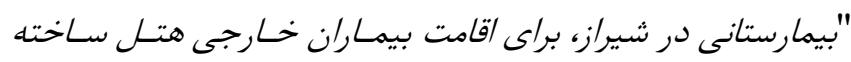

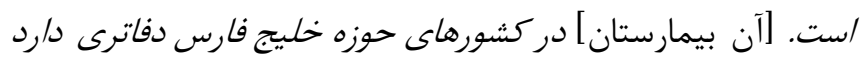

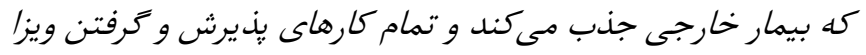

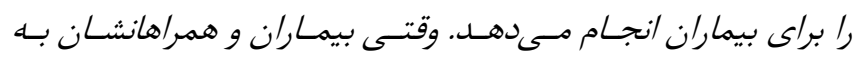

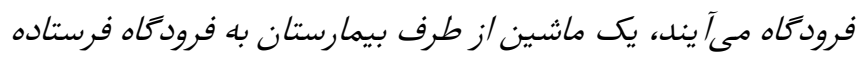

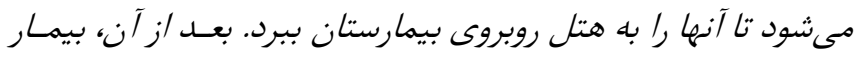

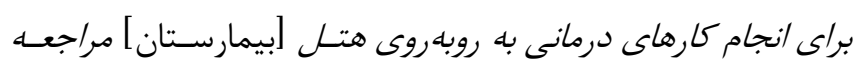

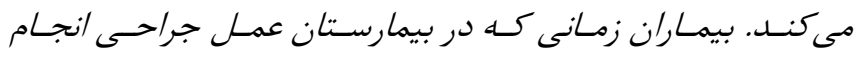

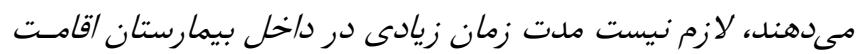

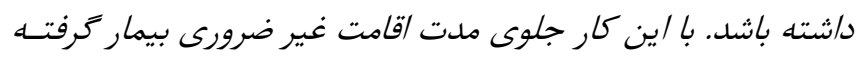

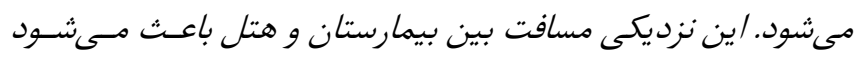

شايستخى، وظيفه شناسـى و خــوش برخـورد بـودن سـاير كاركنـان بيمارستان نيز در جذب بيماران خارجى موثر است. بيماران خارجى برائ

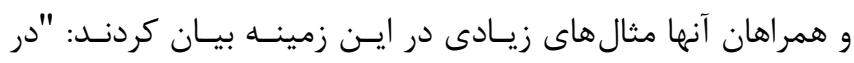

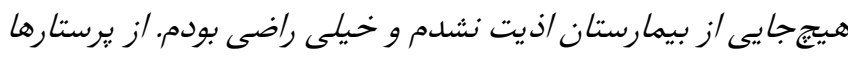

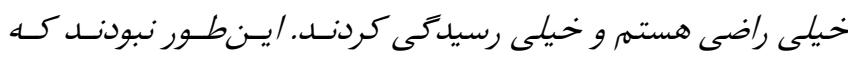

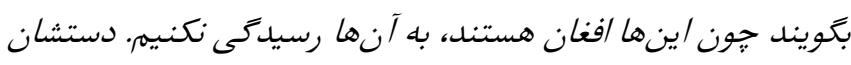

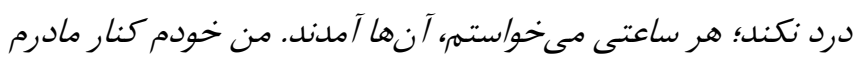

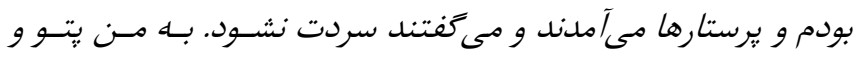

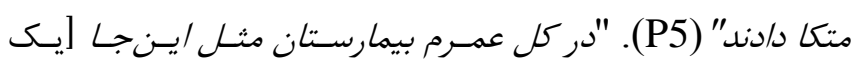

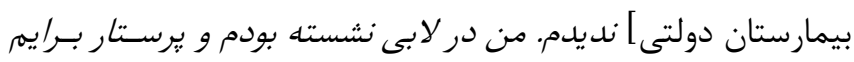

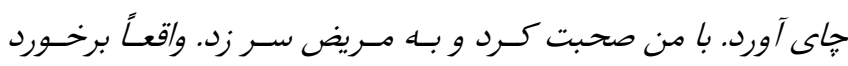

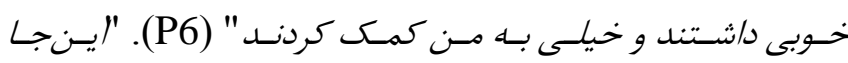

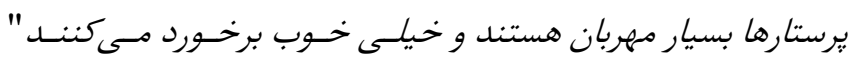

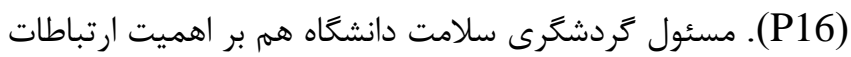

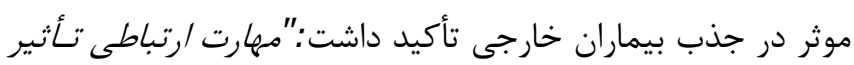

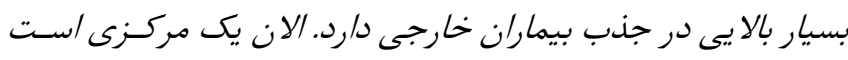

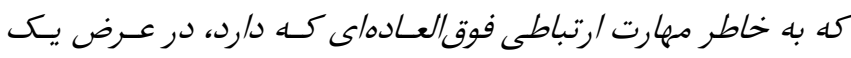

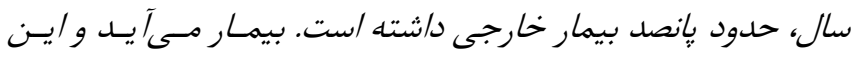

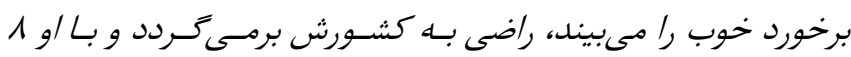

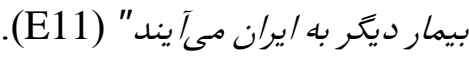

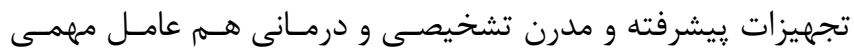

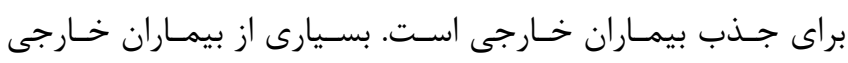

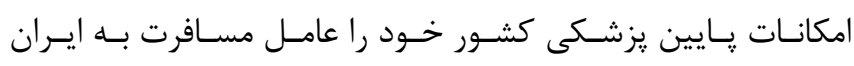

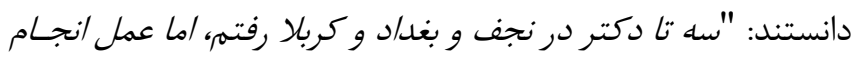

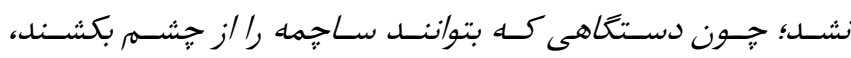

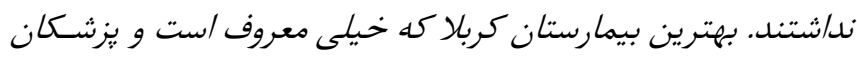

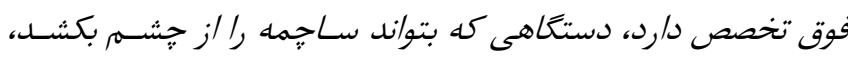

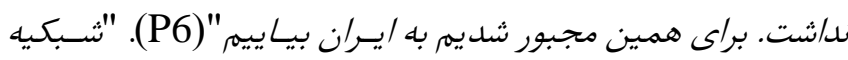

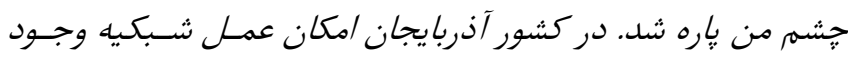

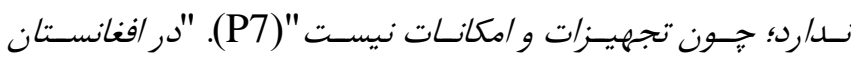

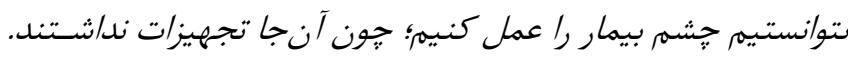

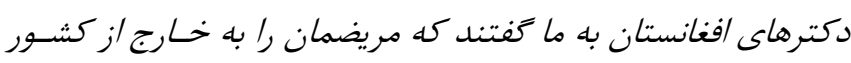

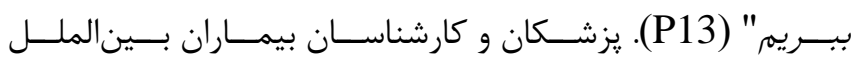

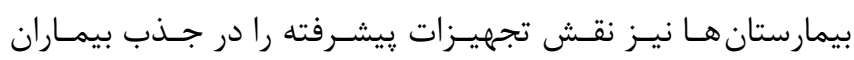

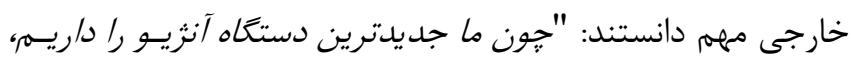

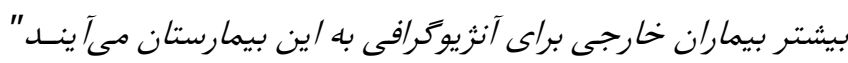


يزشكى برتر معروف بوده /ست. بسيارى /ز بيماران خارجى بـهـاطر

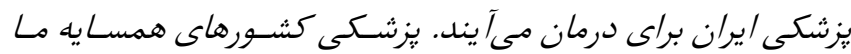

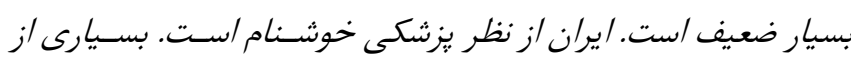

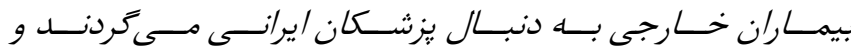

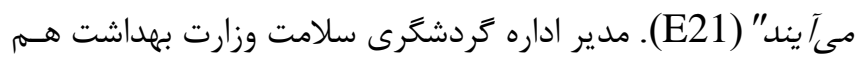

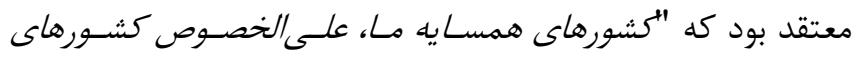
حاشيه خليج فارس /ز ديرباز كشور /يران را به داشتن بيزشكى قـوى

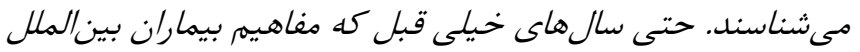

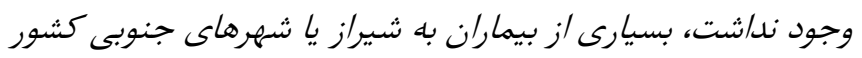

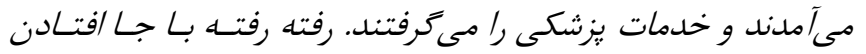

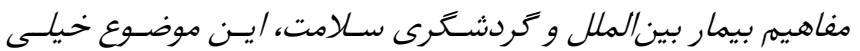

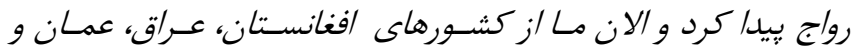

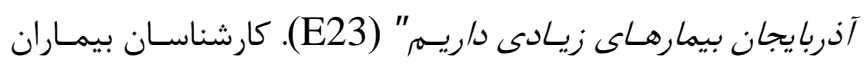

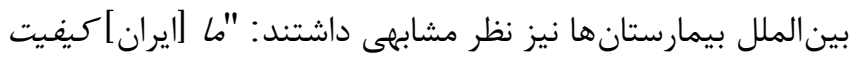

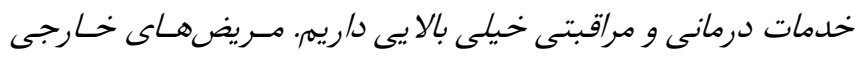

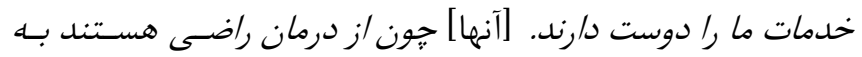
ايران مراجعه مىكنند" (E15).

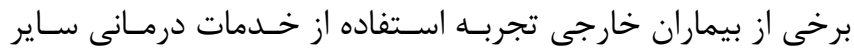

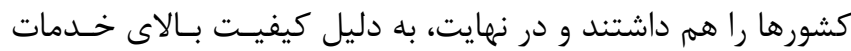
يزشكى در ايران به اين جا مراجعه كردند. بهعنوان مثال، يـك بيمـار

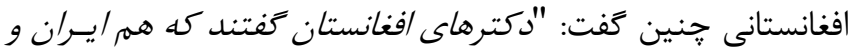
هندوستان براى بيوند خوب هستند، اما، كفتند هندوستان به خاطر

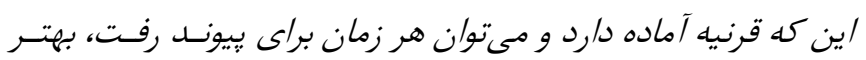

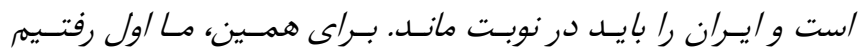

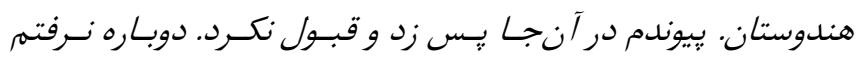

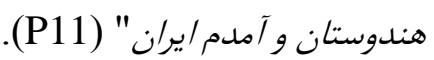

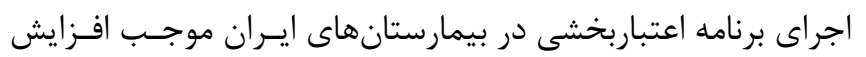

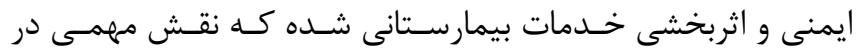

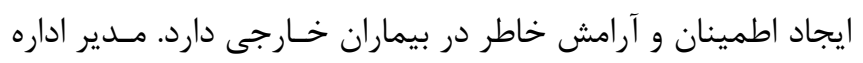

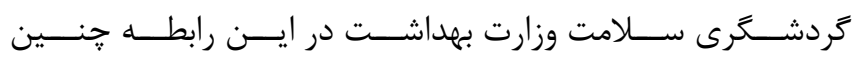

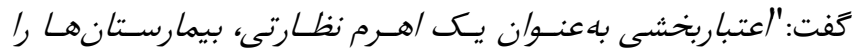

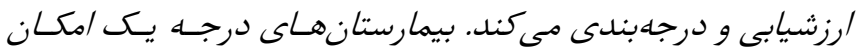

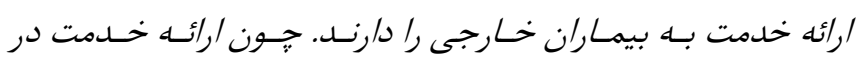

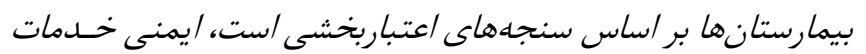

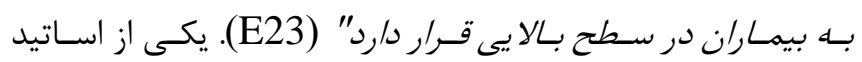

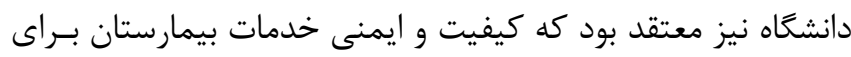

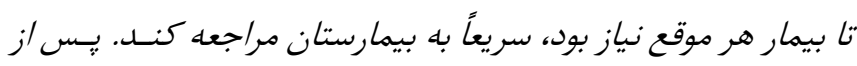

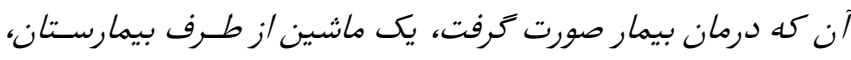

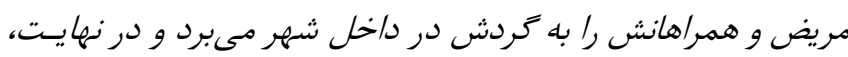
همر آنها را به فرودكاه مىبرد" (E21).

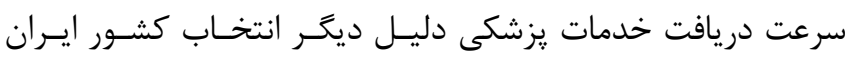

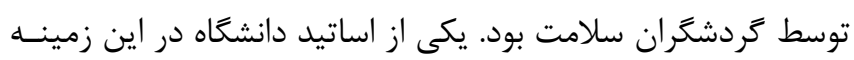

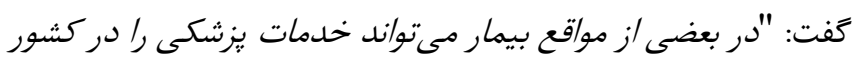

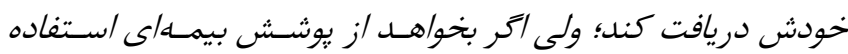

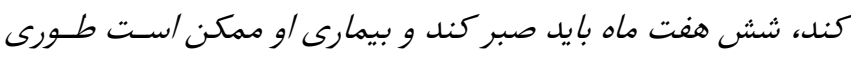

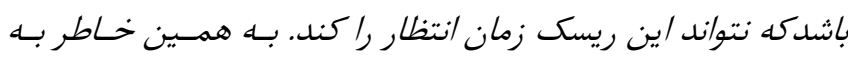
ايران مراجعه ميكند" (E20).

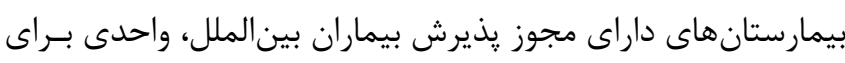

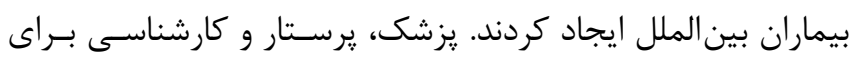

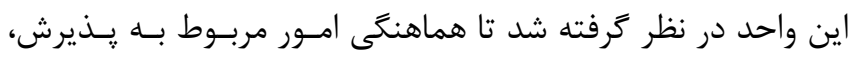

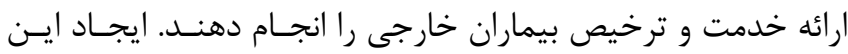

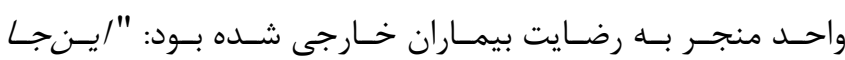

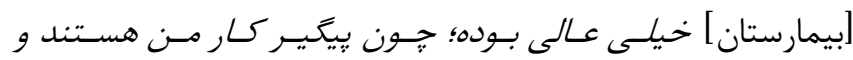

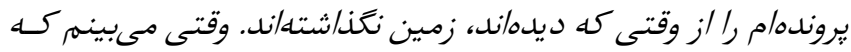

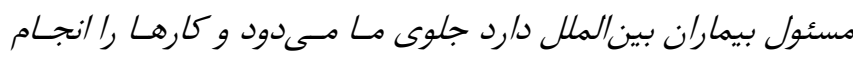

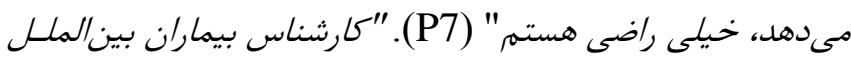

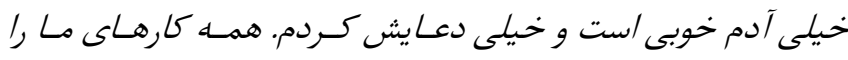

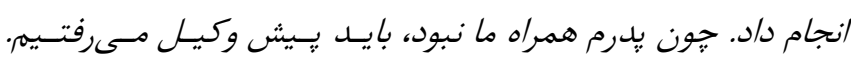

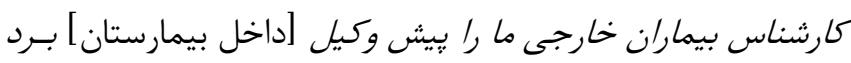

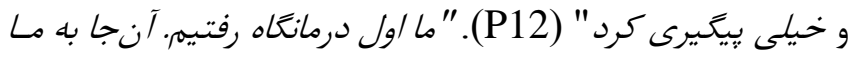

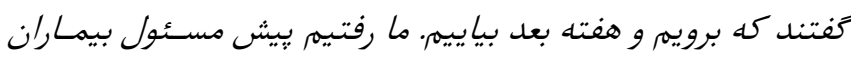

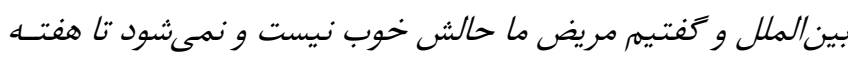

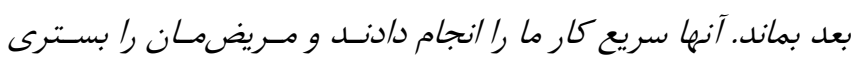

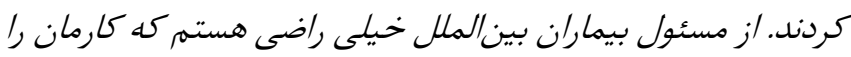

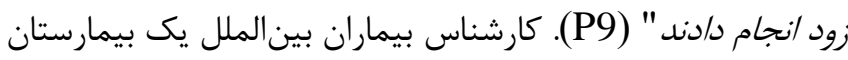

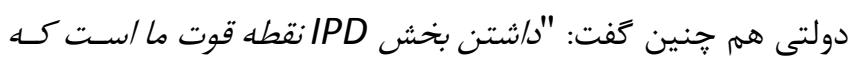

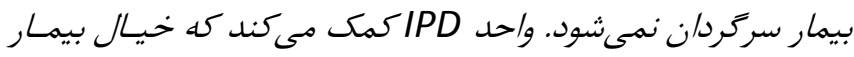

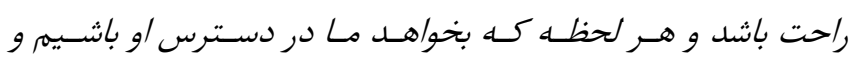

كمكش كنيم" (E10).

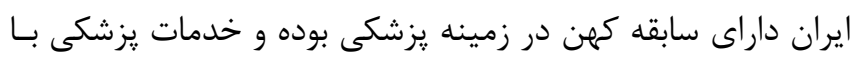

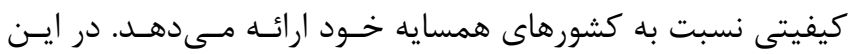

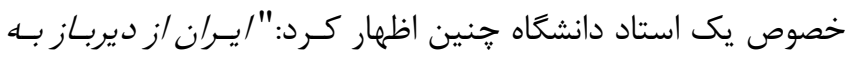


(E10). پايين بودن ارزش يول ايران منجر به كـاهش هزينـهــاى

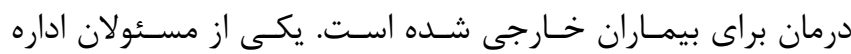

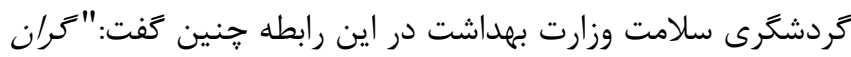

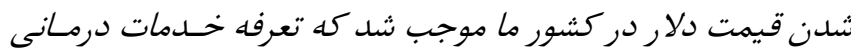

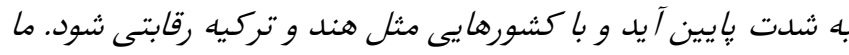

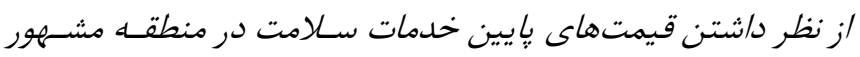

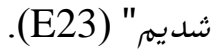

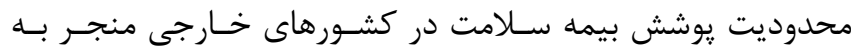

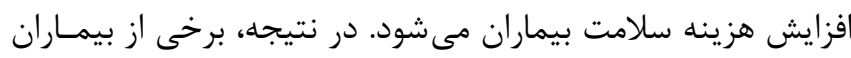

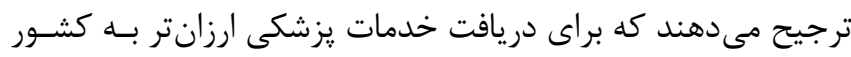

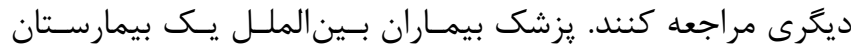

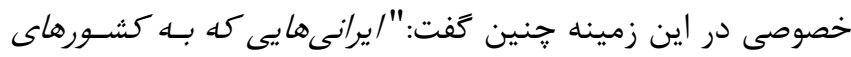

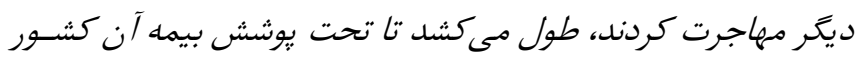

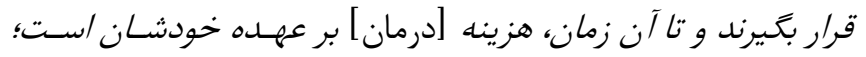

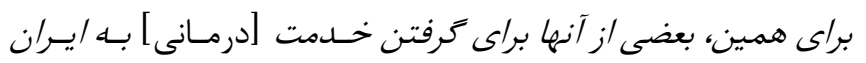

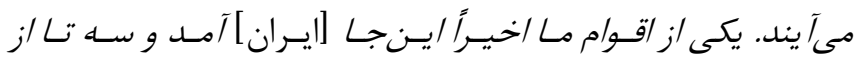

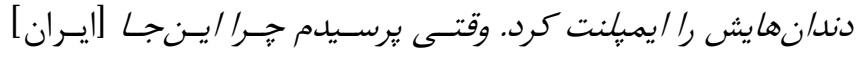

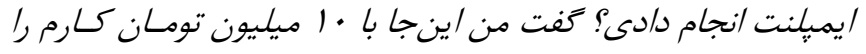

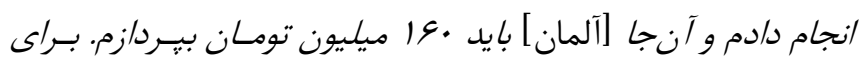

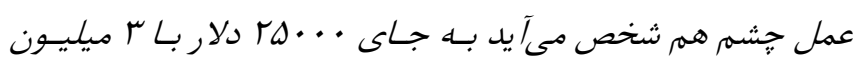

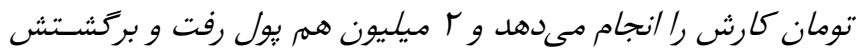

مىشود" (E2). برخى از مصاحبهشدكان اعتقاد داشتند كه تقويت بيمههاى سـلامت

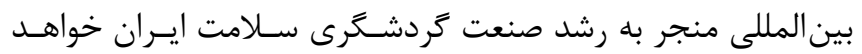

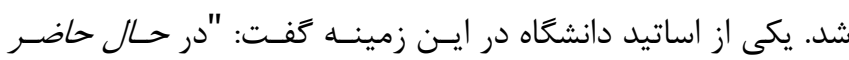

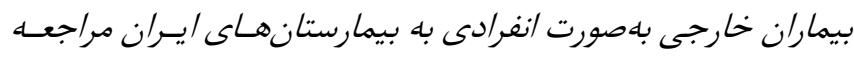

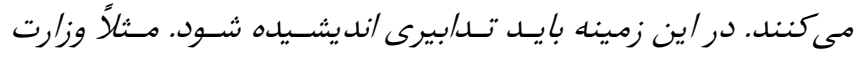

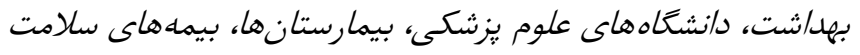

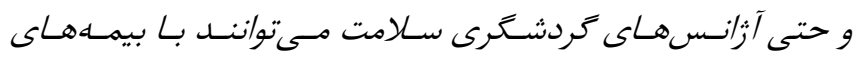

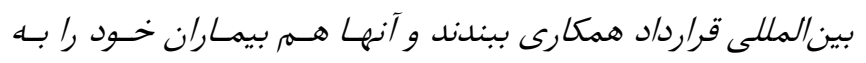

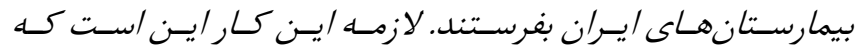

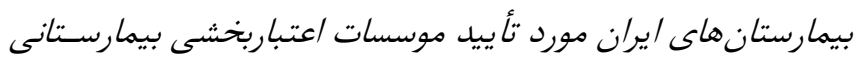

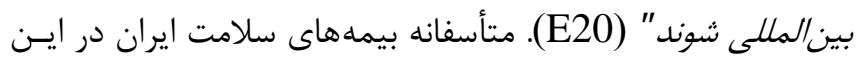

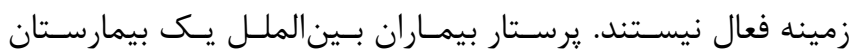

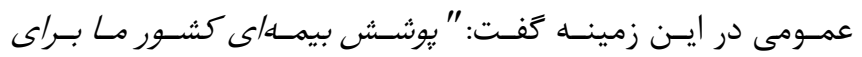

بيماران خارجى بسيار مهم است. گواهى اعتباربخشى بيمارستانى به

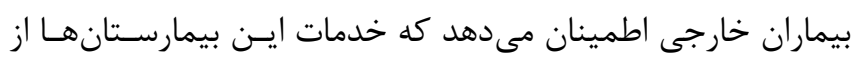

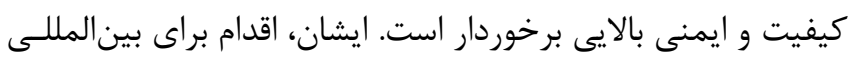

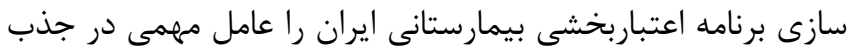

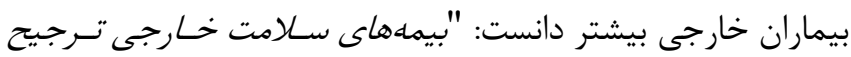

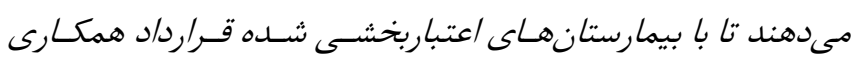

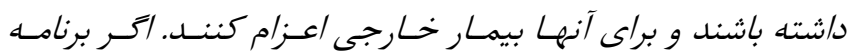

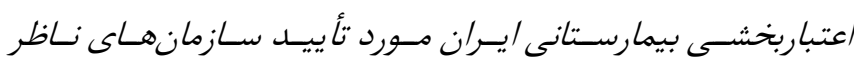

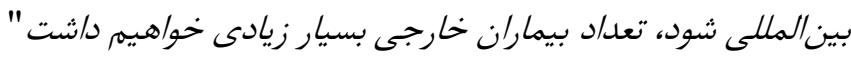

\section{هزينه خدمت}

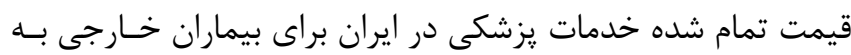

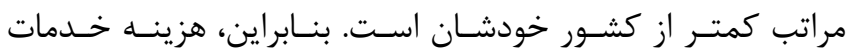

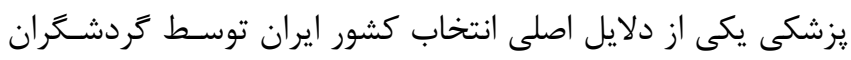

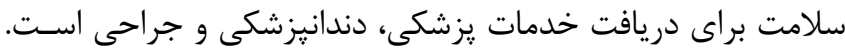

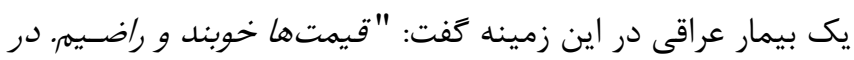

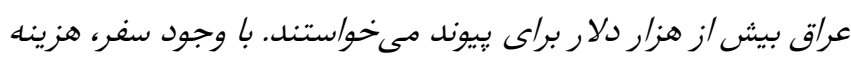

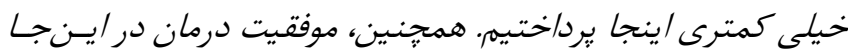

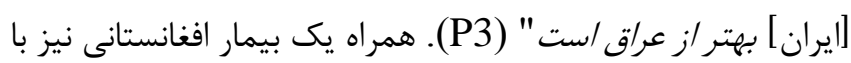

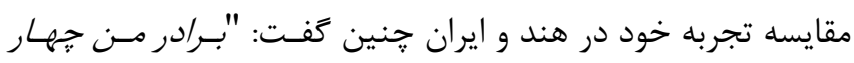

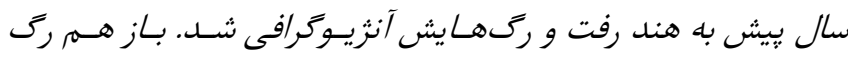

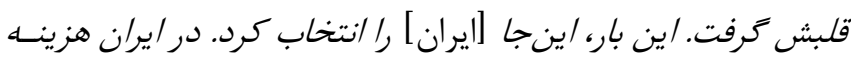

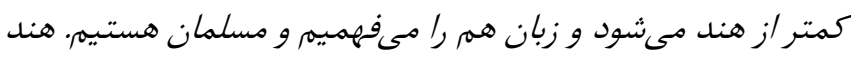

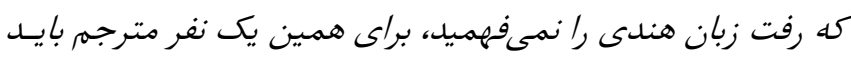

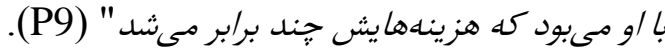

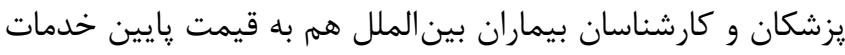

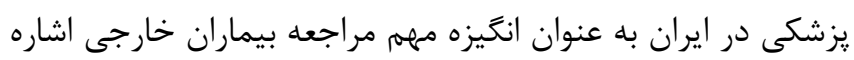

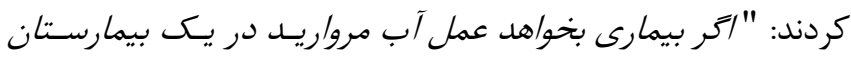

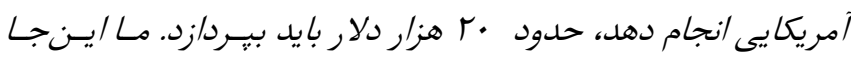

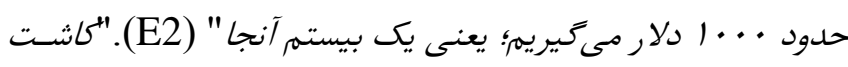

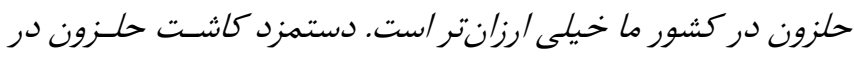

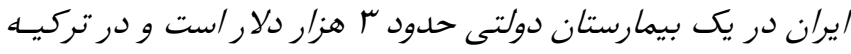

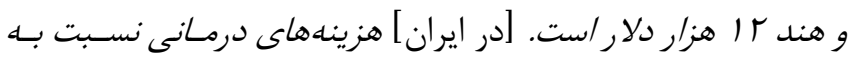

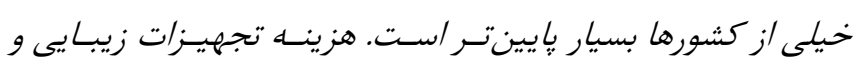

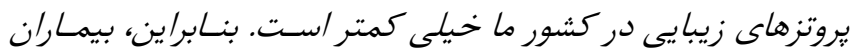

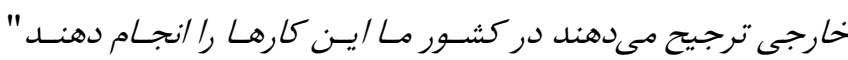




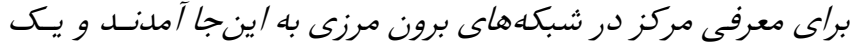

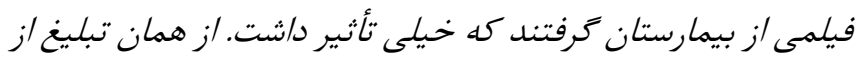

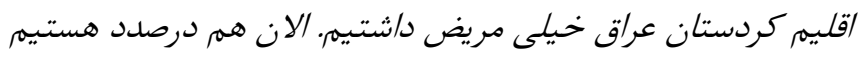
در خود شبكههاى عراق تبليغ انجام دهيم. حضور در نما يشكاهنهاى

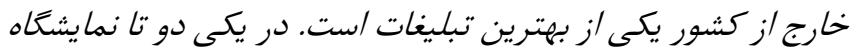

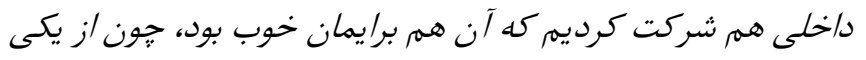

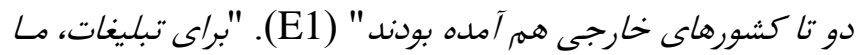

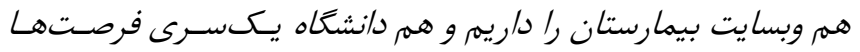

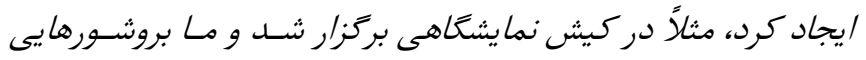

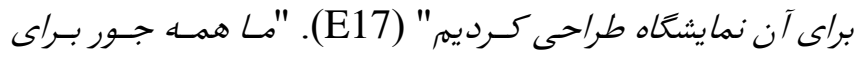

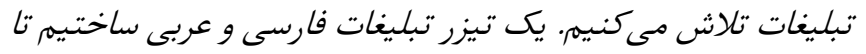

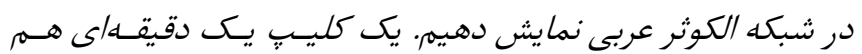

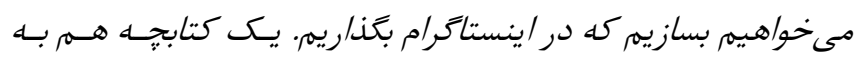

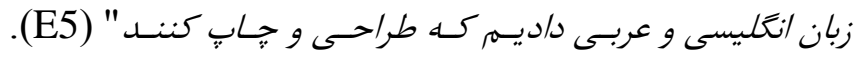

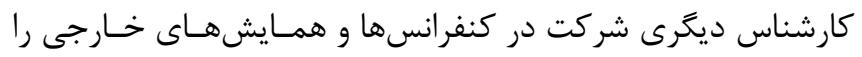

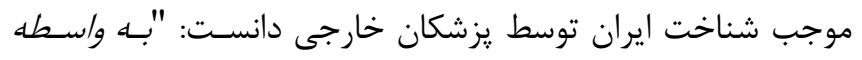

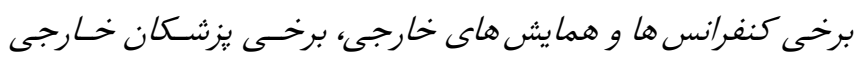

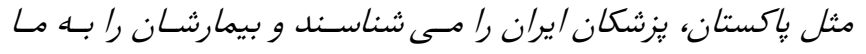

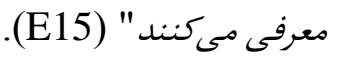

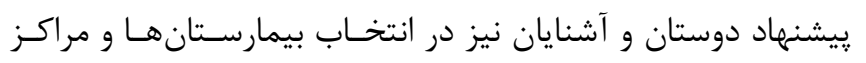

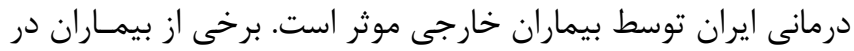

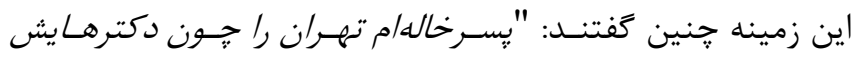

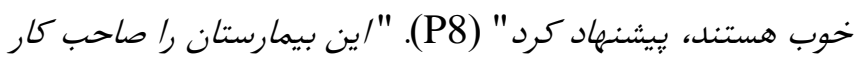
شوهرم بيشنهاد داد و كفت كه دكترهايش خيلى متخصص هستند.

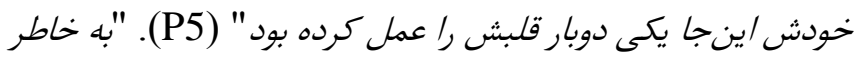

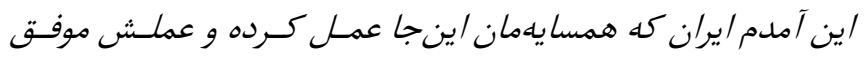

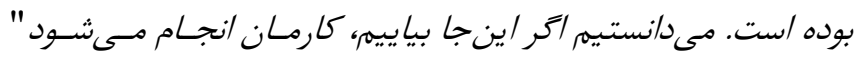

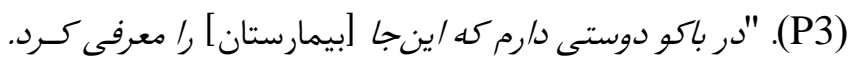

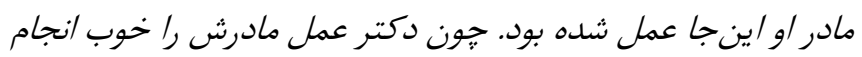

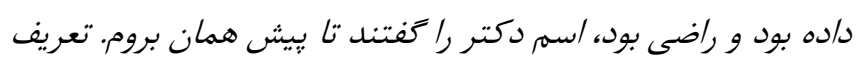

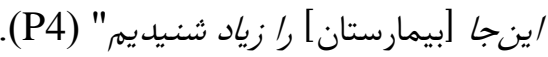

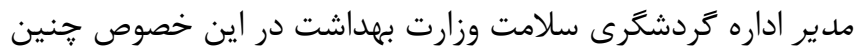

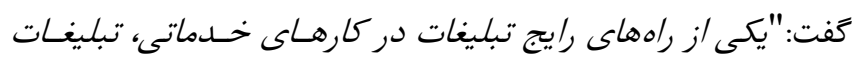

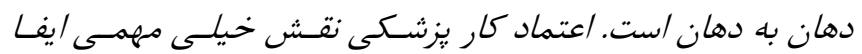

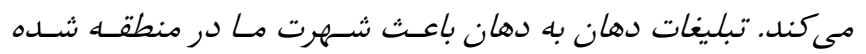

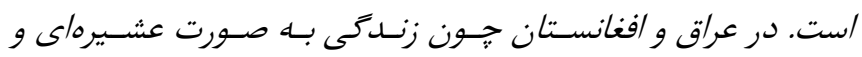

كردشكرهاى سلامت خيلى ضعيف اسـت و تقريباً بيمارهـا از ايـن

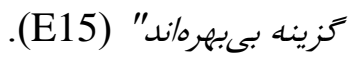

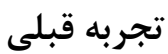
كيفيت بالاو هزينه پإيين خدمات يزشكى ايران موجب كسب ارزش

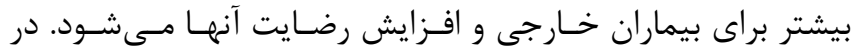

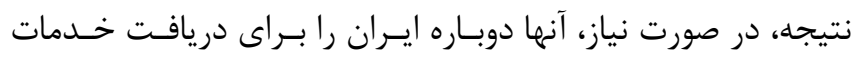

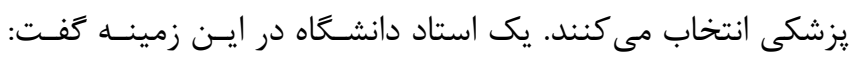

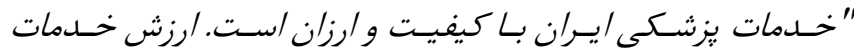

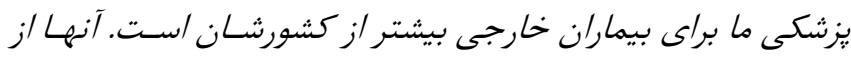

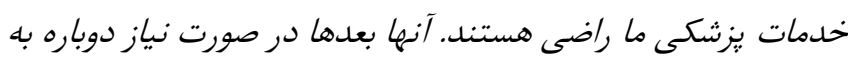

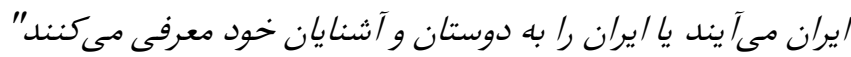

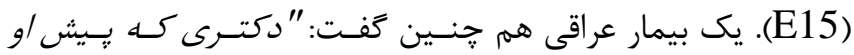

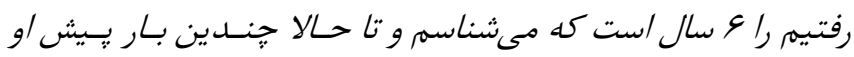

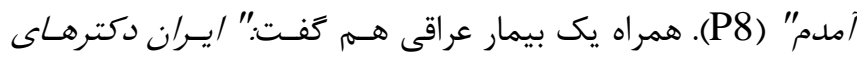

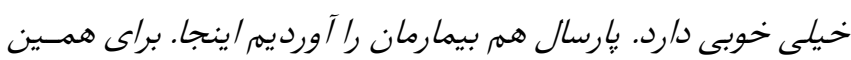
دوباره تهران آمديمر" (P10). تبليغات

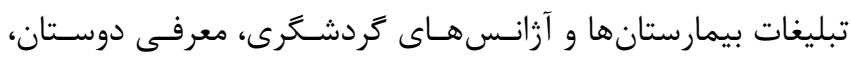

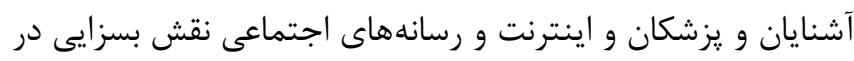

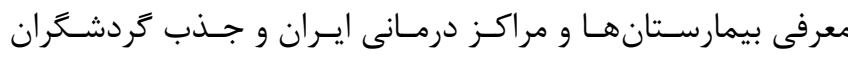

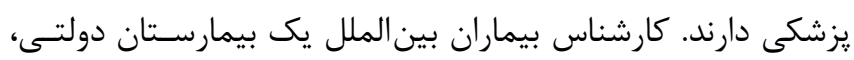

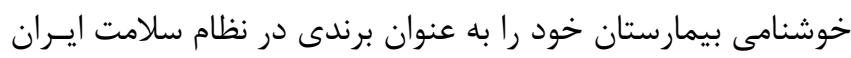

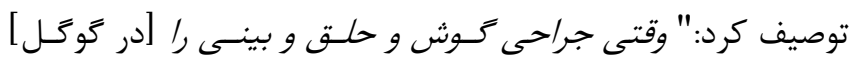

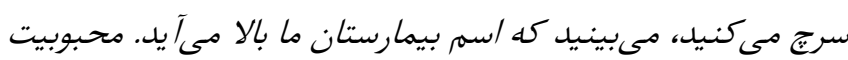

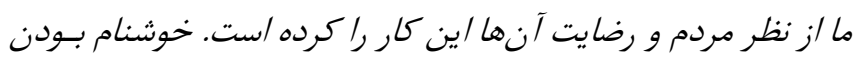
بيمارستان باعث شده كه بيماران خارجى زيـادى بياينــ" (E10).

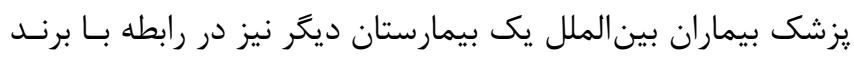

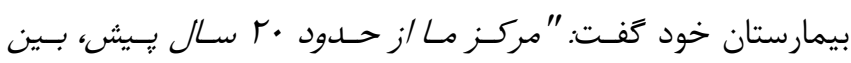

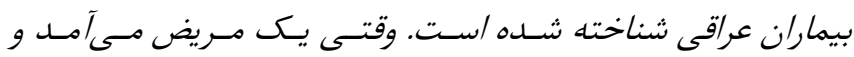

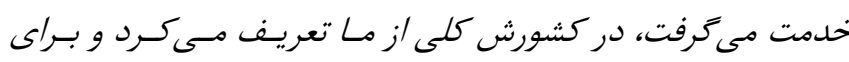

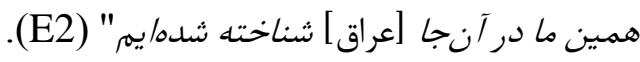

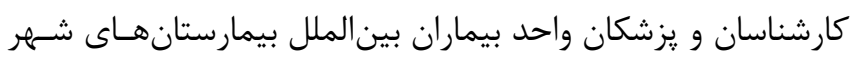

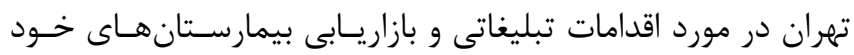

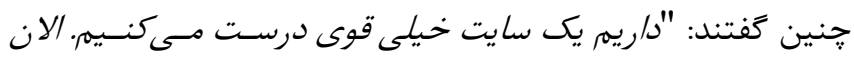

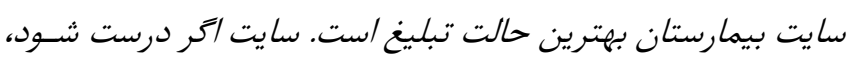
ما /مكان جت داريم. با يكى /ز شبكههاى تلويزيونى قرارداد بستيمه و 
كفت كه دكترهاى /ين جا خيلى خوبند. خـودش /يـن بيمارستان را

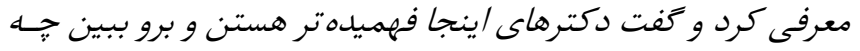

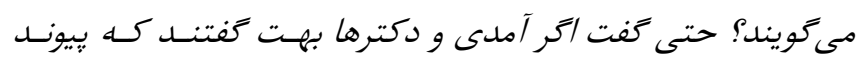

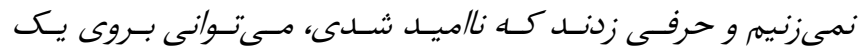

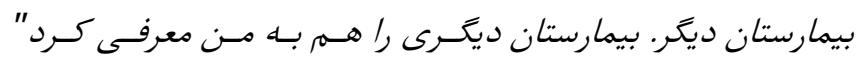

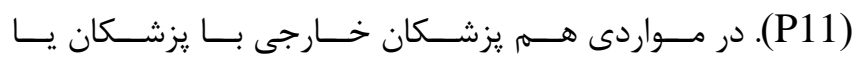

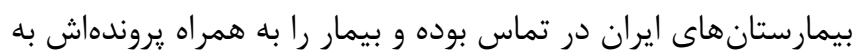

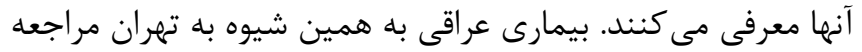

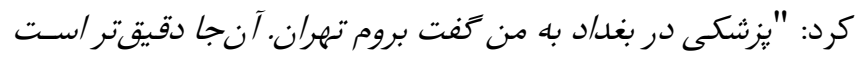

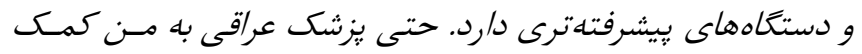

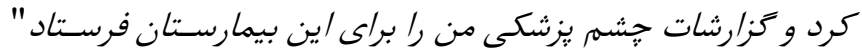

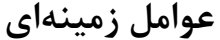

قرابت فرهنكى، جاذبه هاى گردششكرى و جو سياسى از جمله عوامـل

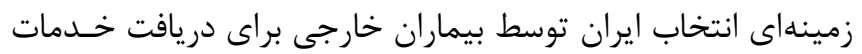

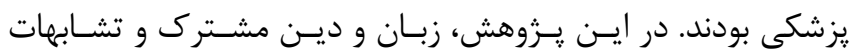

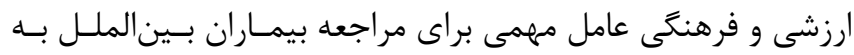

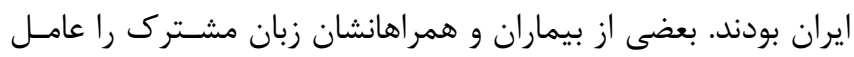

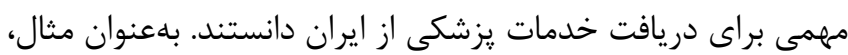

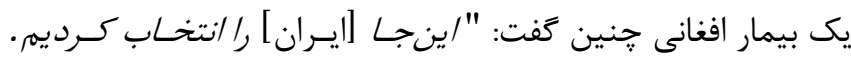

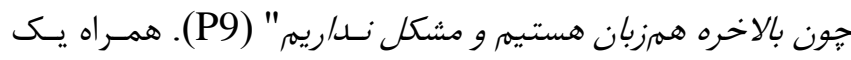

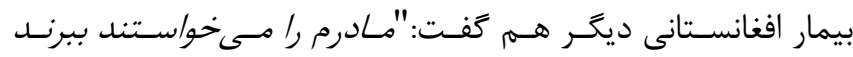

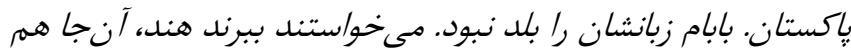

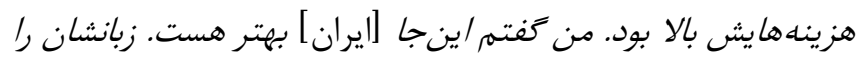

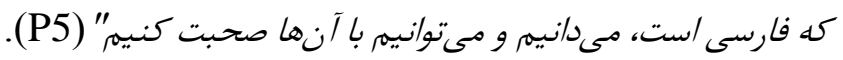

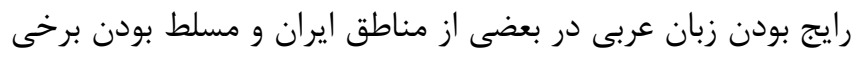

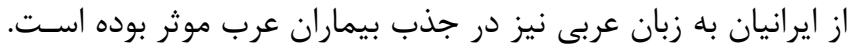

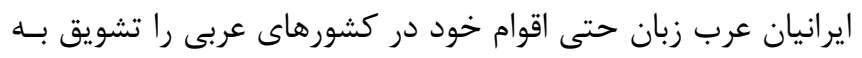

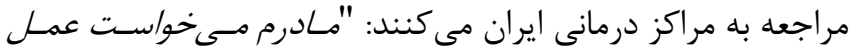

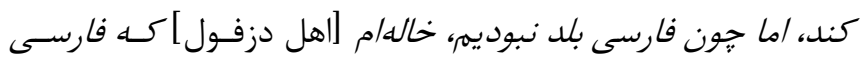

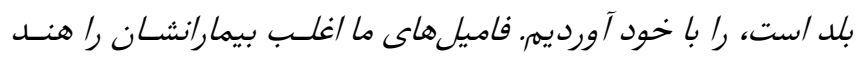

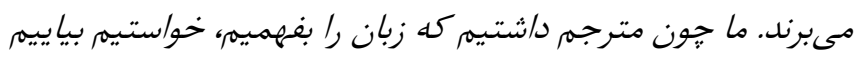

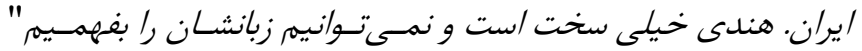

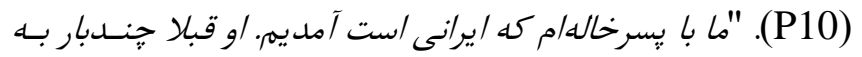

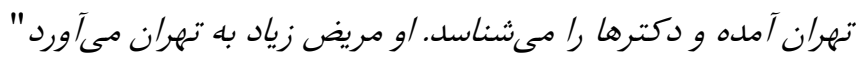

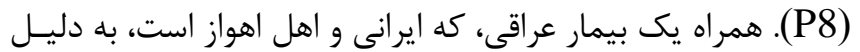

قبيلهاى /ست، وقتى يكى نفر خدمتى را /ز /يران بَّيرد و راضى باشد،

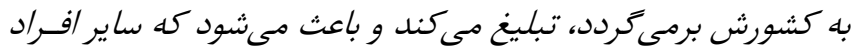

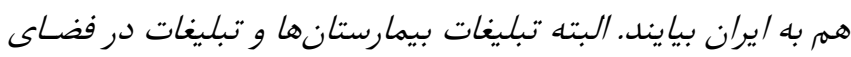
مجازى دارند جاى تبليغات دهان به دهـان را مسىكيرنسـ" (E23).

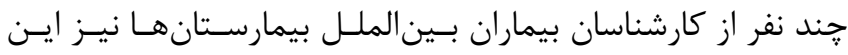

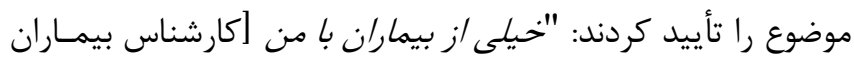

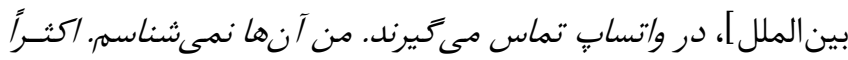

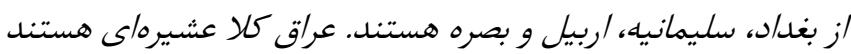

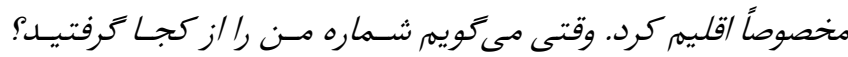

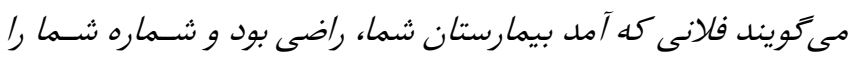

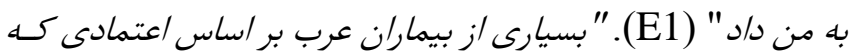

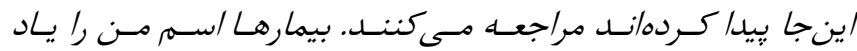

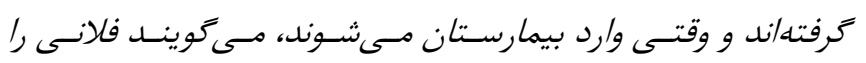
مىخواهيم و /ز من راهنمايى مى كيرند. /ين اعتمـاد بـين ما / يجـاد شده /ست. شماره تلفن من همر دست بيمارها /ست و با خود بيمارها

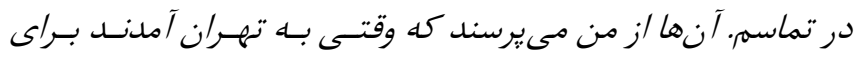

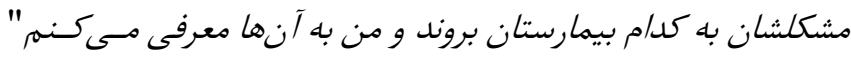

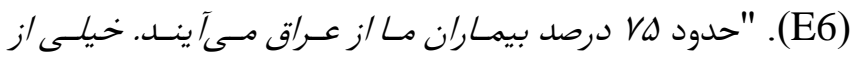

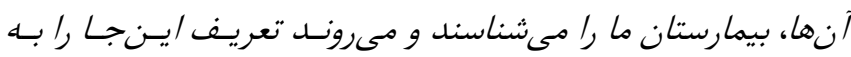

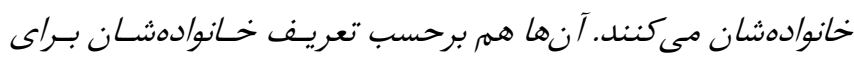

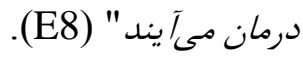

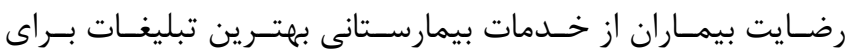

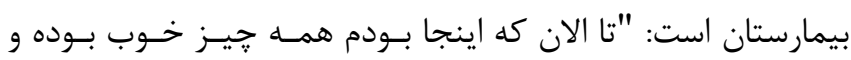
راضى بودم. براى همين اكر كسى براى مريضى از افغانستان بخواهد

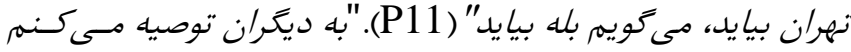

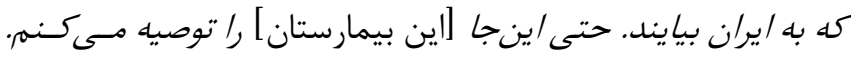

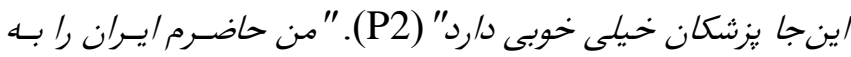

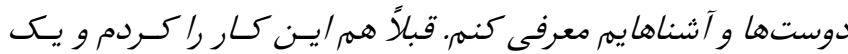

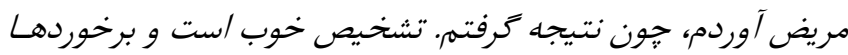

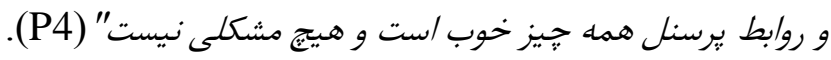

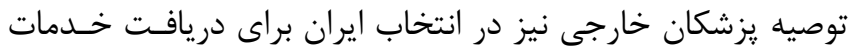

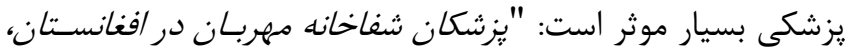

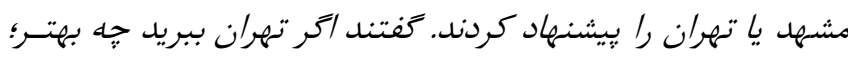

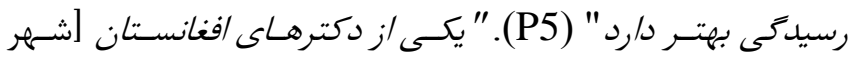

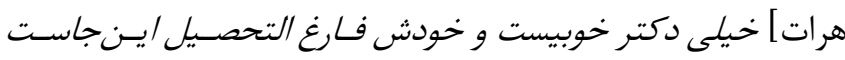

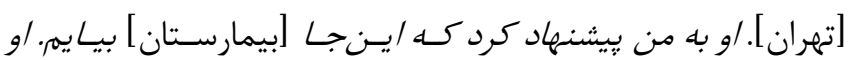


وطن هستند" (P10). درمورد قرابت فرهنكَى ايرانيـان و عـربهـا،

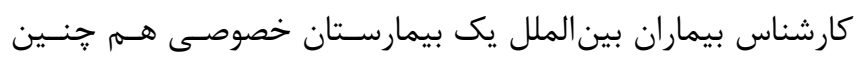

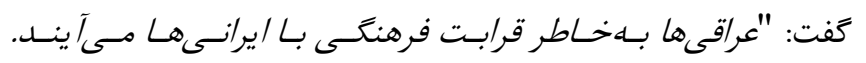

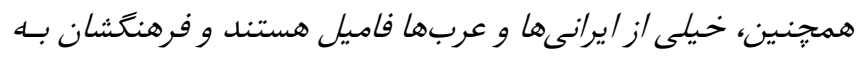

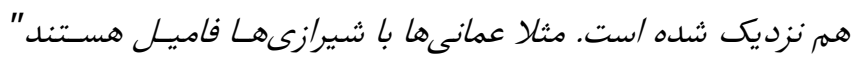

رايج بودن دين اسلام در ايـران نقطـهـ قـوتى در جـذب كَردشـكران

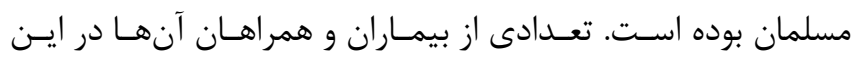

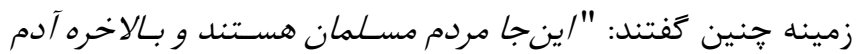

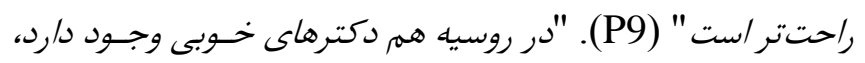

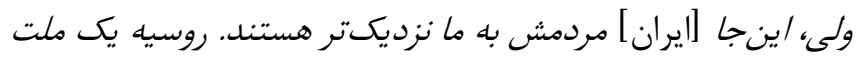

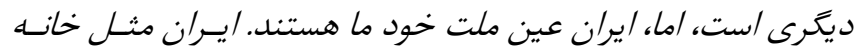
خود ما /ست و خيلى /حساس راحتى دارم. منهم مسـلمانمر و يرانيان

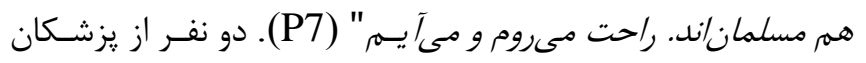

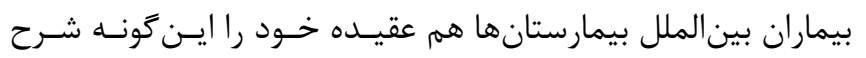

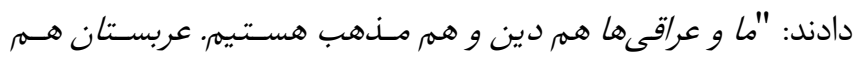

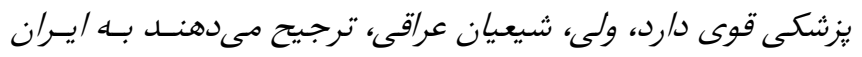

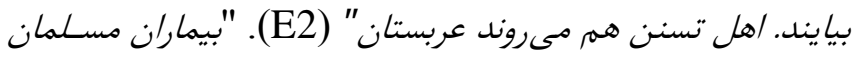

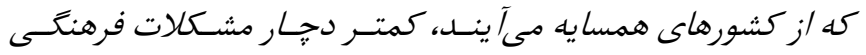

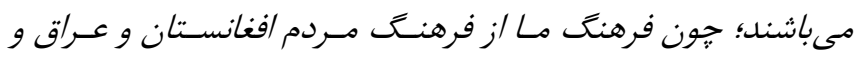

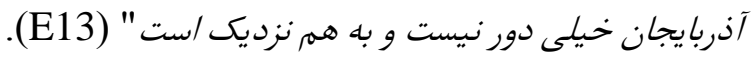

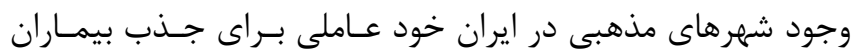

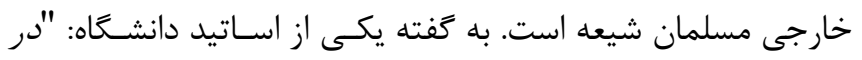

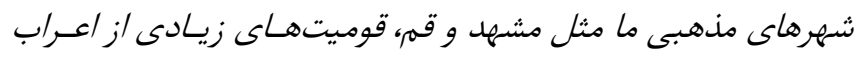

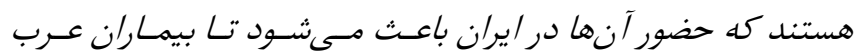
بتوانند /ز طريق آنها وارد بيمارستانهـاى ايـران شـوند" (E20).

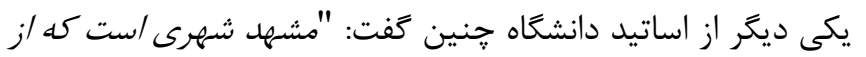

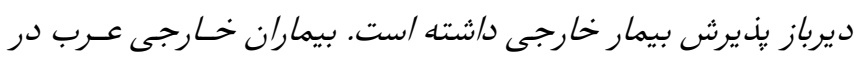

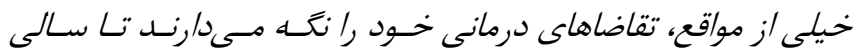

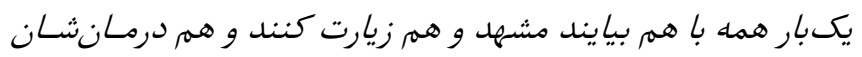

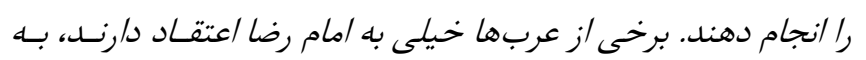

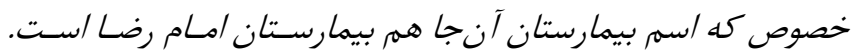

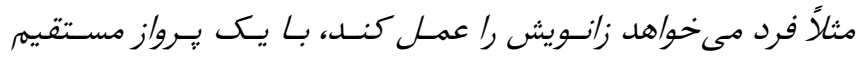

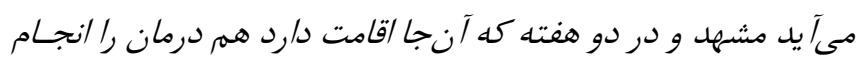

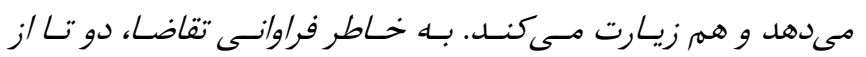

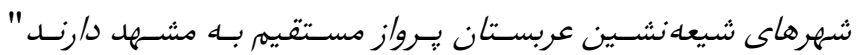

دانستن زبان فارسى و آشنايى با بيمارستانهاى تهران، بيمار خود را

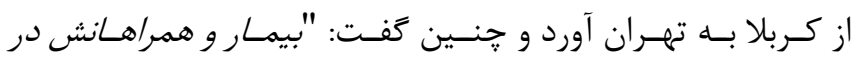

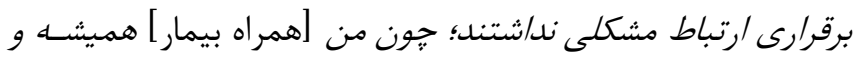

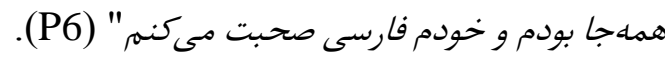

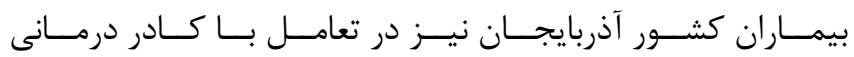

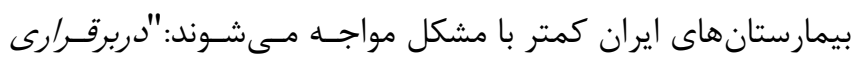

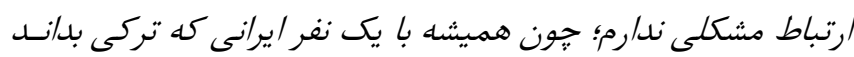

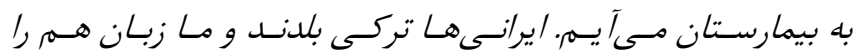

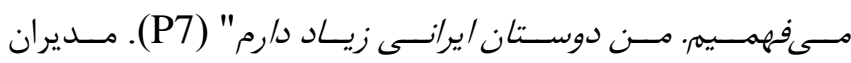

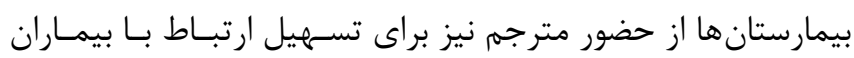

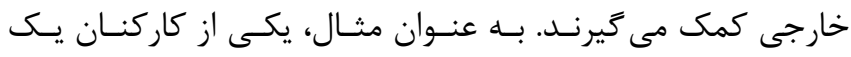

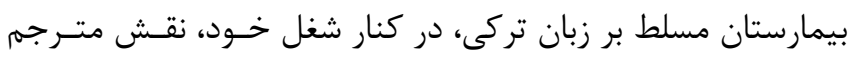

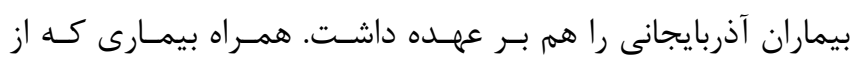

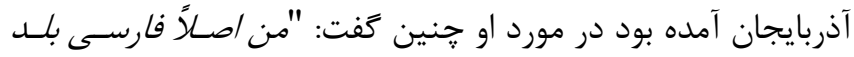

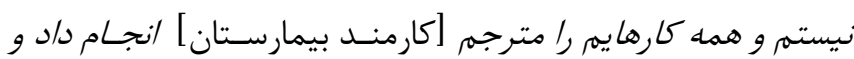

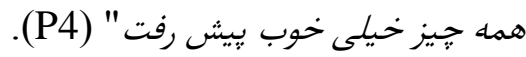

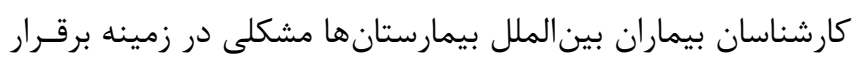

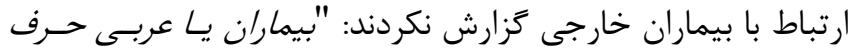

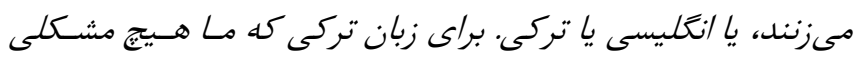

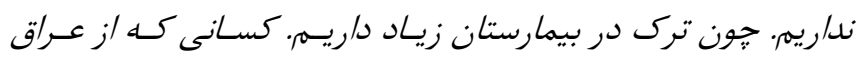

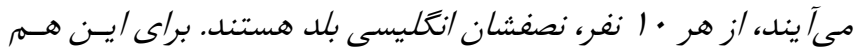

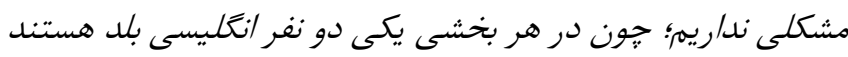

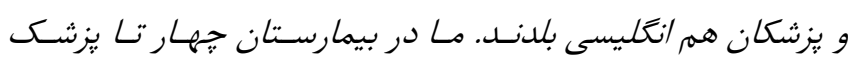

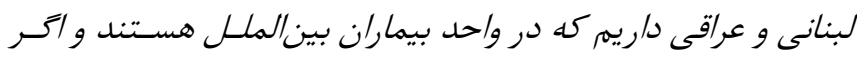

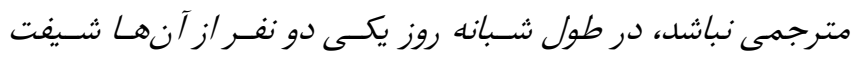

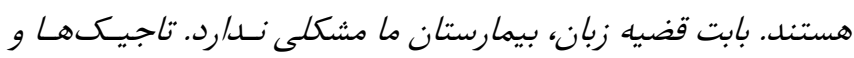

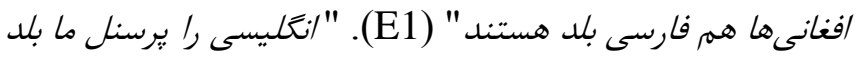

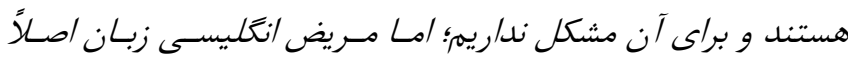

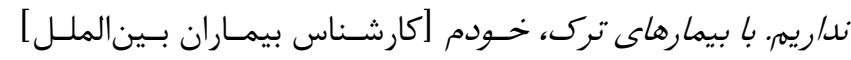

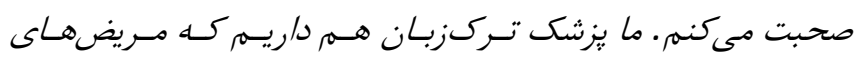

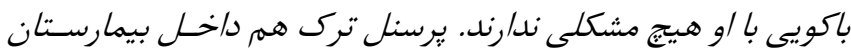

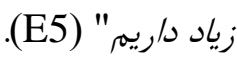

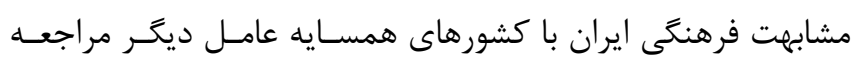

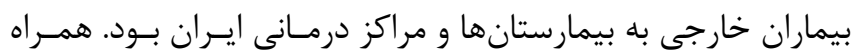
يك بيمار عراقى نظر خود را اين كونه بيان كرد: "ما فكسر مسىكنسيم

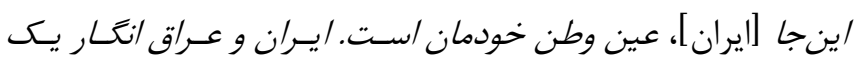


بهداشت هم جنين بود: "سواحل درياى خــر و شـهرهاى جنـوبى

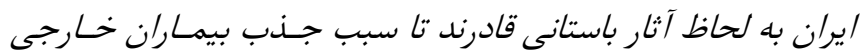

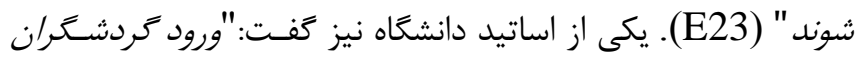

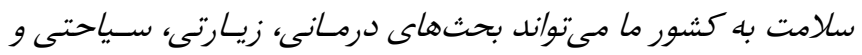

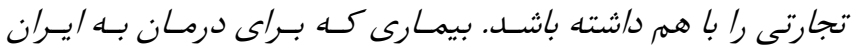

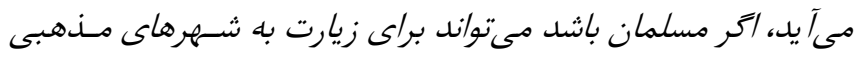

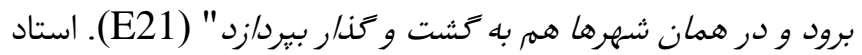
دانشكاه ديخرى هم كَفت: "برخى از بيماران عرب بـان خـانواده بـراى

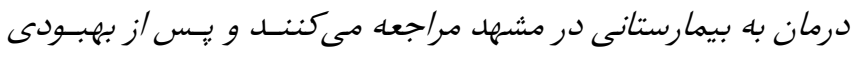

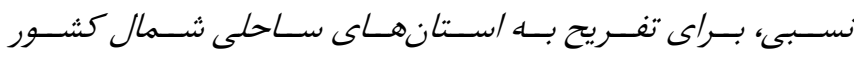

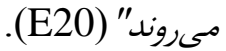
امنيت و شرايط سياسى كشور در دنيا نيز بـر مسـافرت كَردشــران

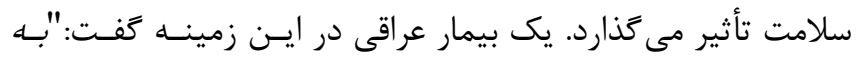

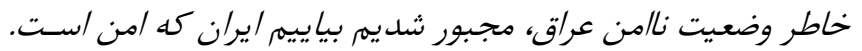

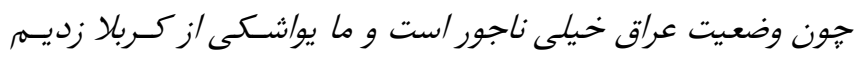

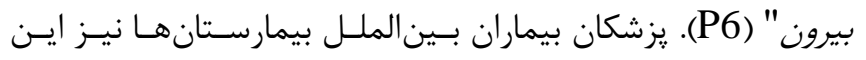

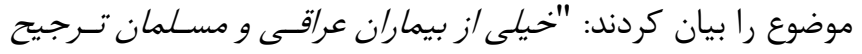

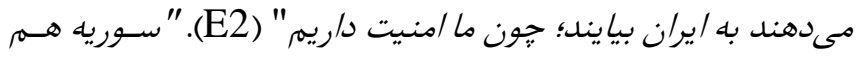

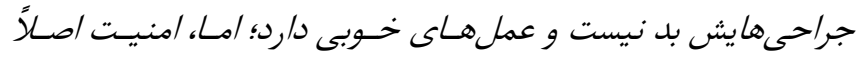
ندارد و بيماران به آنجا نمىروند" (E2).

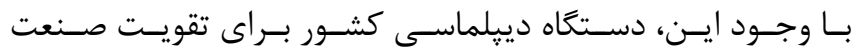

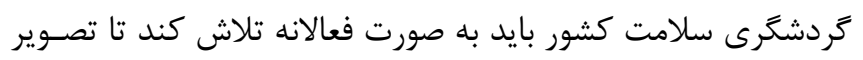

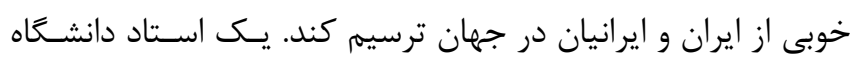

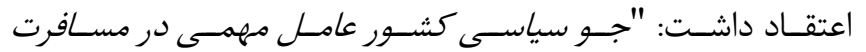

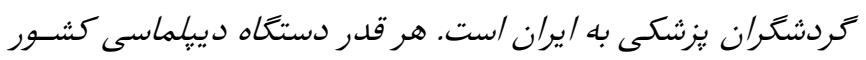

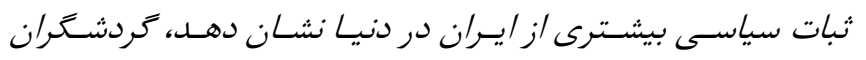

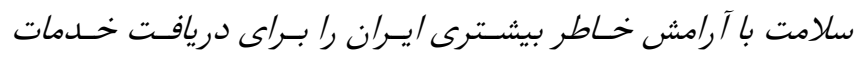

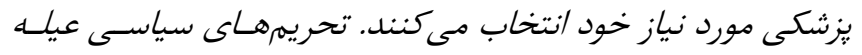

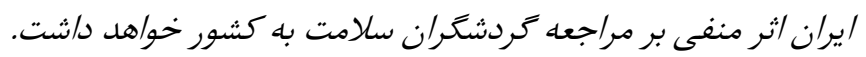

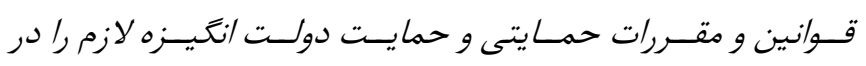

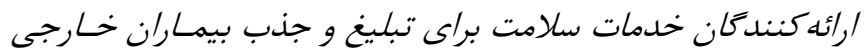

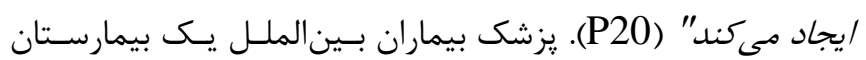

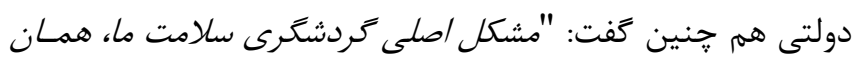

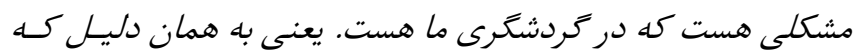

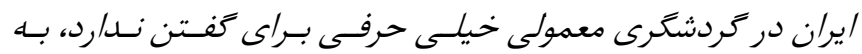

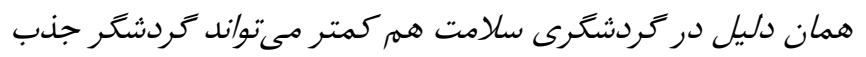

(E21). اين موضوع را يكى از يزشكان بيماران بينالملل نيز تأييـد

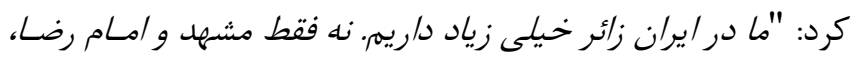

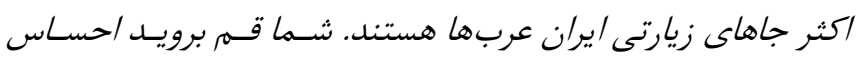

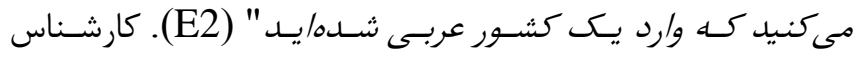

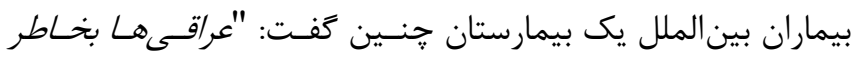

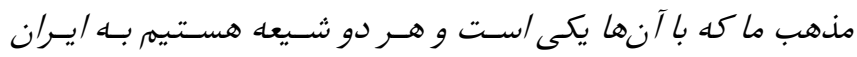

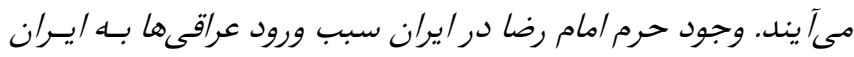

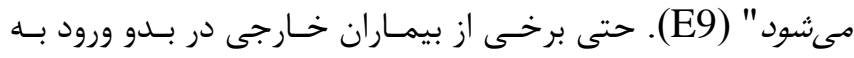

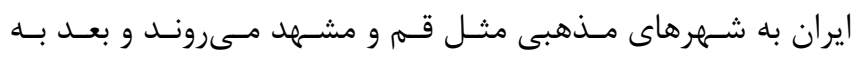

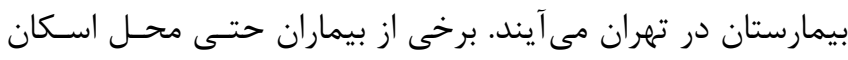

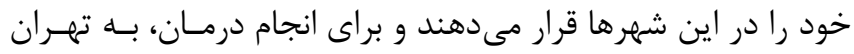

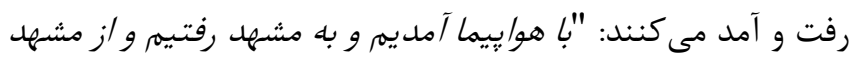

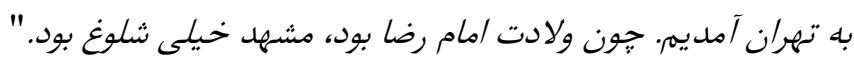

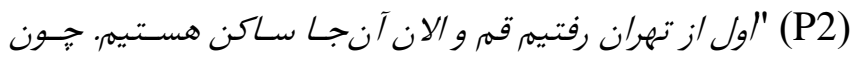

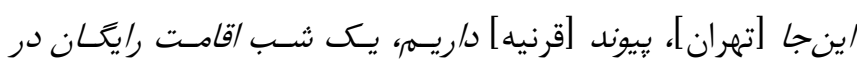

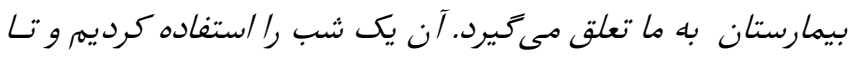
مراجعه بعدى به قمر رفتيمه الان دوباره آمديم تا دكتر معاينه كنسـد و

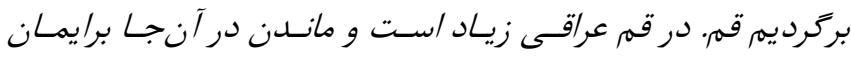

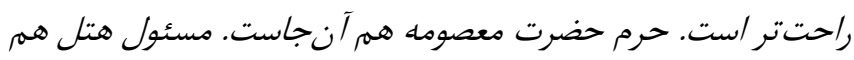

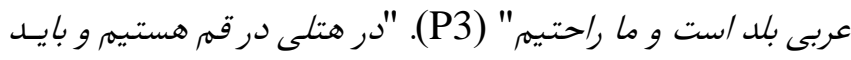

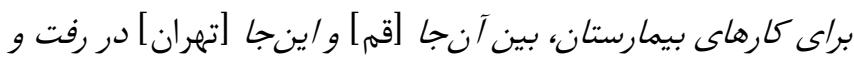

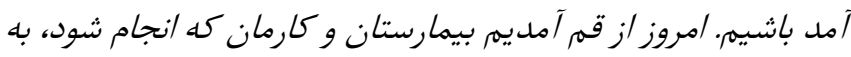

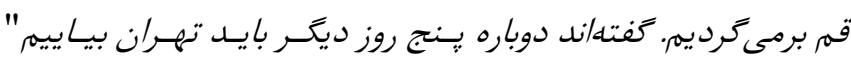
در خصوص جاذبههـاى كردشـكرى سـاير شـهرهاى ايـران، يكسى از

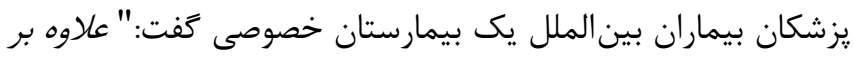

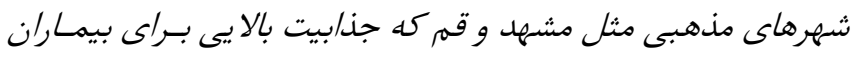

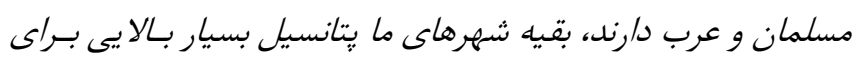

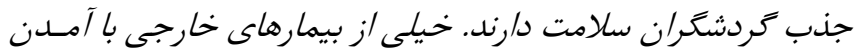

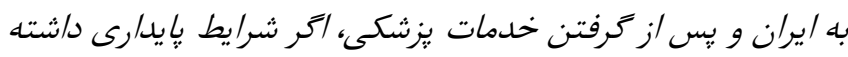

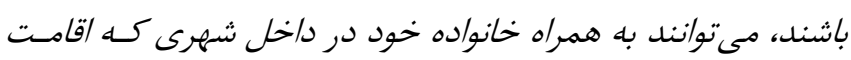

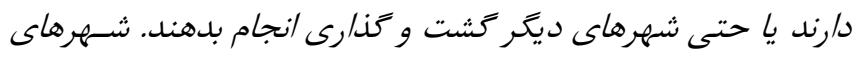

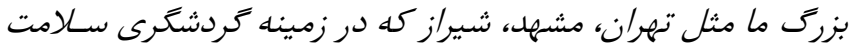

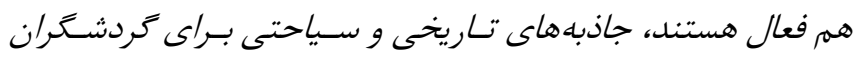

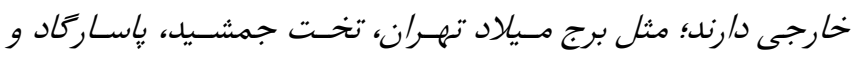

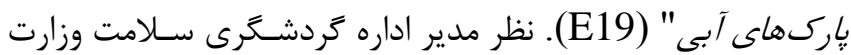


كمتر /ز هند مىشود. برادرم إبيمار ]ل، كارمند دولـت /ست و مشتهل

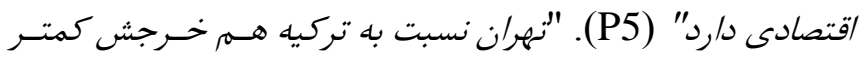

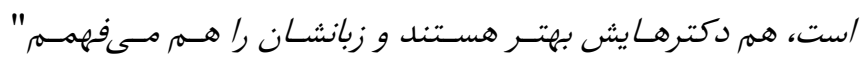

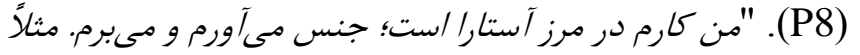

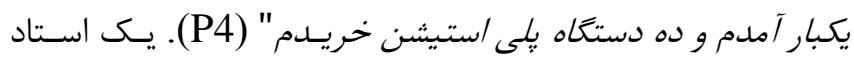

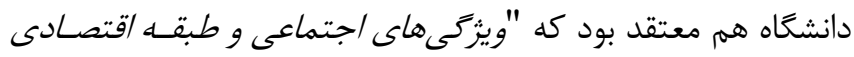

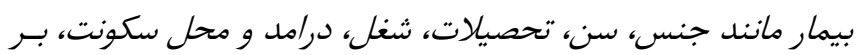

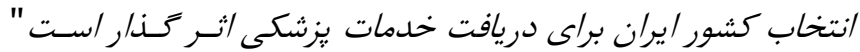

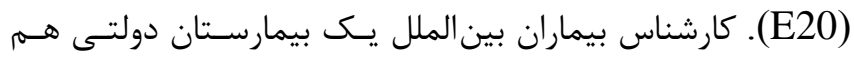

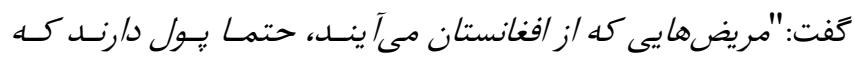

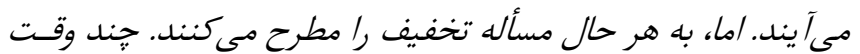

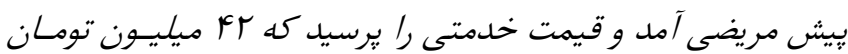

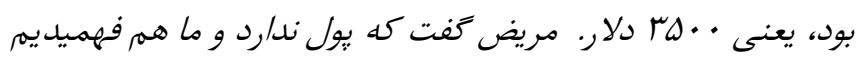

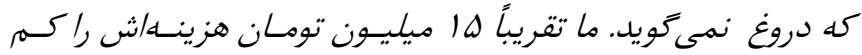

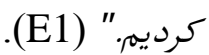
محل سكونت بيمار و دسترسى سريع و راحت او بــه ايــران و مراكـز

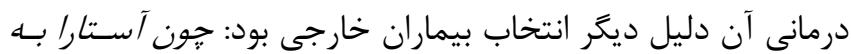

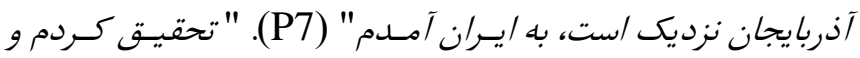

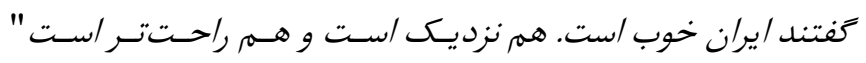
(P4). "خانه/م تا مرز [مرز ايران و عراق] دو ساعت و نيمر راه /ست.

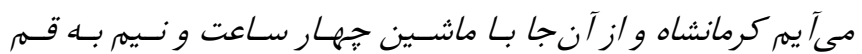

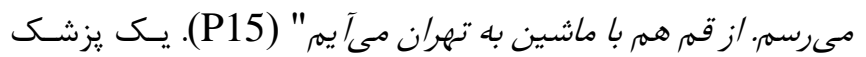

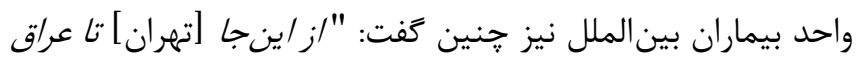

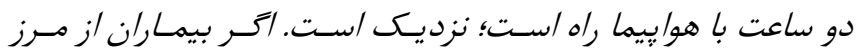

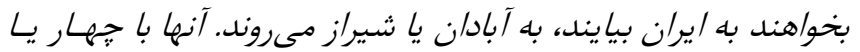

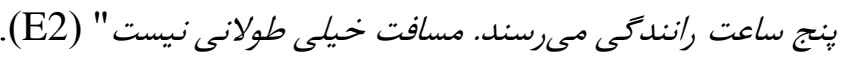

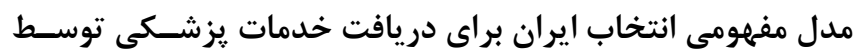
تر دشكَران يزشكى

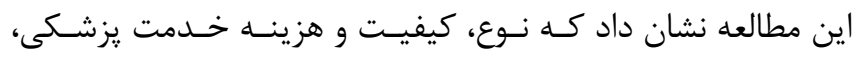

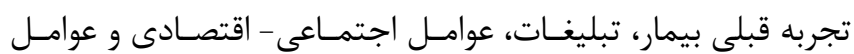

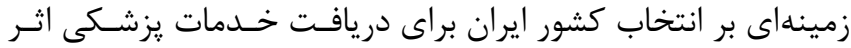

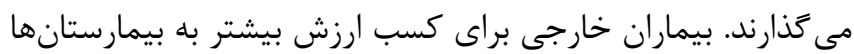

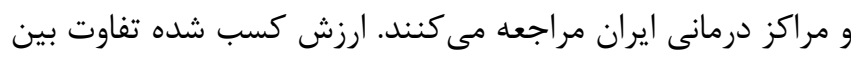

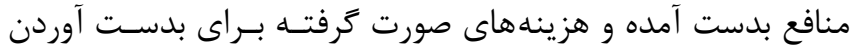

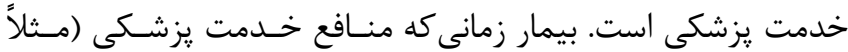

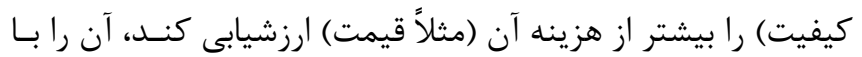

كند. شايد يكى /ز راهها /ين باشد كه كمى وجهه /يران در دنيا بهتـر

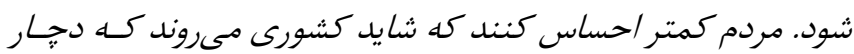

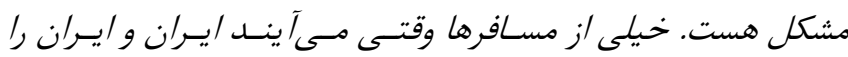

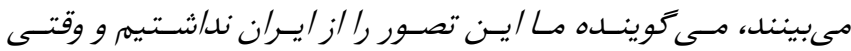

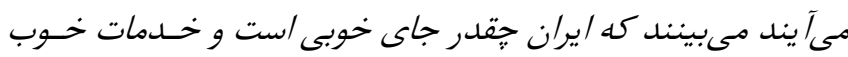

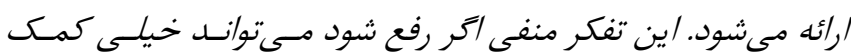

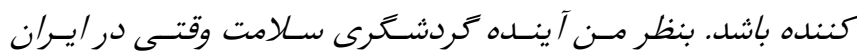

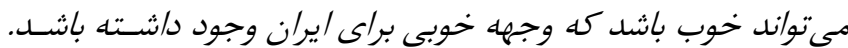

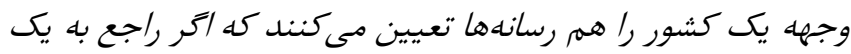

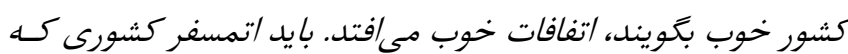

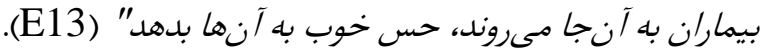

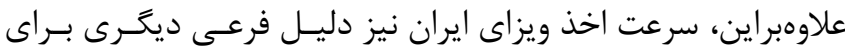

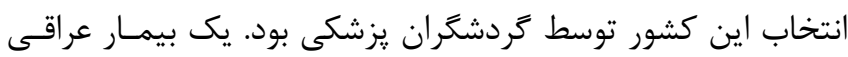

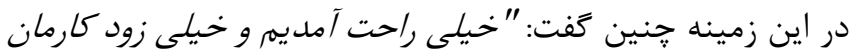

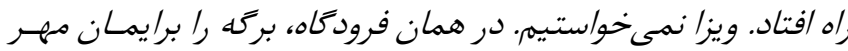

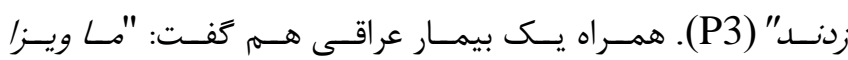

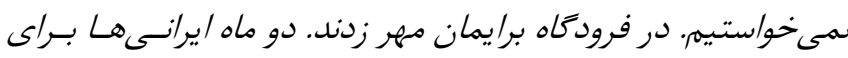

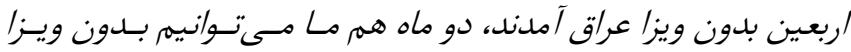

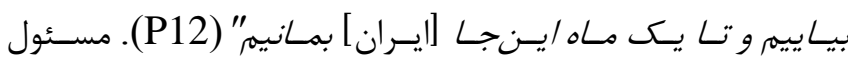

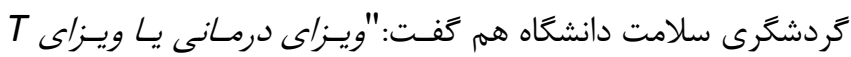

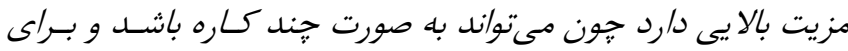

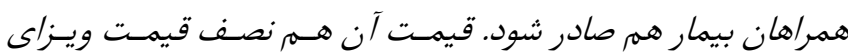

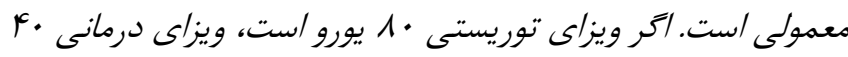

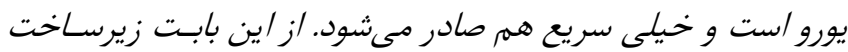

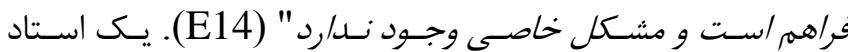

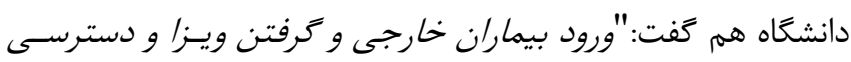

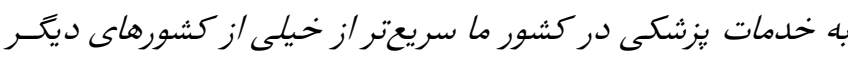

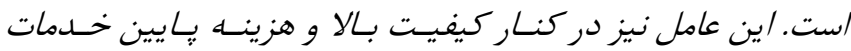
يزشكى ما، منجر به تشويق بيماران خارجى براي مراجعه بـه مراكـز درمانى ما شده /ست" (E20).

\section{عوامل اجتماعى - اقتصادى بيمار}

عوامل اجتماعى و اقتصادى مرتبط با بيمار بــر انتخــاب يــ كشــور

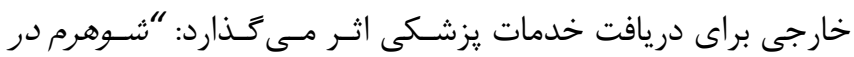

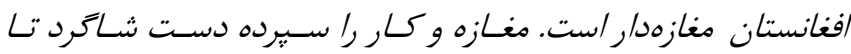

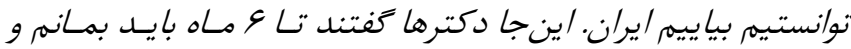

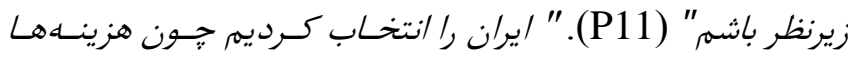


خود، بر نخَرش آنها اثـر مثبـت داشـته و منجــر بــه انتخــاب مجـدد

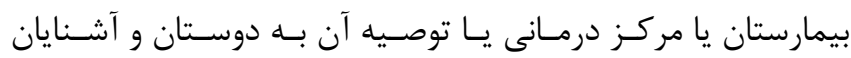
خواهد شد. نمودار ا مدل مفهومى انتخاب كشور ايران براى دريافت خدمات يزشكى توسط گردشگران يزشكى را نشان مى مهدي.
ارزش تلقى مى كند. هزينه شامل هزينه يولى يرداختى براى خدمت يزشكى و هزينه غير يولى نظير زمان صرف شده، تلاش، جسـتجو و زحمت يافتن و بدست آوردن آن خدمت است. كيفيت بالا و هزينـه نيه يايين خدمات يزشـكى ايــران منجـــر بــه افـزايش ارزش درك شـده

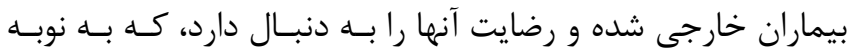

جدول ا: اطلاعات جمعيتشناختى مصاحبهشوندكان

\begin{tabular}{|c|c|c|c|c|c|c|}
\hline \multicolumn{2}{|l|}{ كل } & \multicolumn{2}{|c|}{ كارشناسان } & \multicolumn{3}{|c|}{ بيماران و همراهان } \\
\hline درصد & فراوانى & درصد & فراوانى & درصد & فراوانى & \\
\hline & & & & & & جنسيت \\
\hline$r_{N} / \mathrm{A}$ & $r$. & $9 D / r$ & 10 & TV/A & $\Delta$ & زن من \\
\hline$\Delta 1 / r$ & r) & $r r / \Lambda$ & $\wedge$ & $V T / T$ & ir & 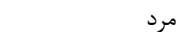 \\
\hline VA & rT & $99 / 9$ & 19 & $1 \mathrm{~N} / 9$ & 19 & متأها \\
\hline rt & 9 & $r \cdot / \varphi$ & v & $11 / 1$ & r & مجرد | مجرد \\
\hline $9 / 1$ & f & $F / r$ & 1 & $19 / 9$ & $r$ & سن بر حسب سال \\
\hline $49 / \pi$ & 19 & rq/1 & 9 & $\Delta \Delta / \Delta$ & 1. & $r \cdot-r$ \\
\hline$r q / r$ & Ir & $F V / q$ & 11 & $\Delta / 9$ & 1 & $\Delta \cdot-\psi \mid$ \\
\hline $9 / 1$ & r & $N / V$ & $r$ & $11 / 1$ & $r$ & G.-DI \\
\hline$r / 4$ & 1 & . & . & $\Delta / Q$ & 1 & $V \cdot-91$ \\
\hline$T / 4$ & 1 & . & . & Q/9 & 1 & $\Lambda \cdot-v 1$ \\
\hline ou & & & & & & وضعيت تحصيلى \\
\hline$\pi / \lambda$ & 1 & ${ }^{\circ}$ & ${ }^{\circ}$ & गात & 1 & بيسواد \\
\hline$r / 4$ & 1 & . & . & Q/S & 1 & ابتدايى \\
\hline$I T / K$ & $\Delta$ & . & . & TV/A & $\Delta$ & زيردييلم \\
\hline$V / r$ & r & . & . & 1919 & $r$ & دييلم \\
\hline$r / \varphi$ & 1 & . & . & D/4 & 1 & فوق دييلم \\
\hline $19 / 0$ & $\wedge$ & $\mid V / F$ & t & Tr/T & r & ليسانس \\
\hline$|V /|$ & $v$ & $r \cdot / \uparrow$ & v & · & . & فوق ليسانس \\
\hline$r / q$ & r & $\Lambda / V$ & r & . & . & يزشك عمومى \\
\hline$K F / F$ & 1. & $\kappa r / Q$ & 1. & . & . & دكترى تخصصى \\
\hline
\end{tabular}

جدول r: علل انتخاب ايران توسط بيماران خارجى براى دريافت خدمات يزشكى

\begin{tabular}{|c|c|c|}
\hline كدها & مضامين فرعى & 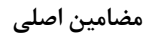 \\
\hline نوع بيمارى بيمار و عدم امكان درمان در كشور مبدأ & نوع بيمارى & \\
\hline شدت بيمارى بيمار، اوررانسى بودن بيمارى و اضطرار زمان & شدت بيمارى & نوع خدمت \\
\hline خدمات جامع و كامل يزشكى & 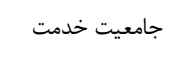 & \\
\hline دانش، مهارت، خوش برخورد بودن و شهرت يزشكان & يز بكان شايسته & \\
\hline وظيفهشناسى و خوش برخورد بودن كاركنان & كاركنان شايسته & \\
\hline تجهيزات يِشرفته يزشكى و تنوع تجهيزات يزشكى & 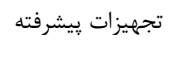 & 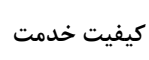 \\
\hline 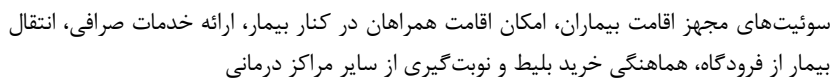 & امكانات رفاهي & \\
\hline
\end{tabular}


خدمت ممتاز، ايمن و اثربخش يزشكى و درجه اعتباربخشى بيمارستان

خدمت ارزان و قيمت تمام شده پايين

عدم يوشش بيمهاى خدمت يزشكى در كشور مبدأ و پوشش بيمهاى خدمت يزشكى در كشور

مقصد

مراجعه قبلى بيمار و رضايت بيمار از ارزش خدمات يزشكى مف

برند بيمارستان، سايت بيمارستان، تبليغات تلويزيونى برون مرزى، نمايشعاههاى داخلى و خارجى و

فضاى مجازى

واسطهها، آرانسهاى گردشكَى در ايران و آرانسهاى گردشكرى در كشور مبدأ

ييشنهاد توسط دوستان و آشنايان و تبليغات دهان به دهان

ارجاع بيمار توسط يزشكان خارجى و يزشكان ايرانى

جستجو در اينترنت، رسانهاى اجتماعى و شبكههاى اجتماعى

زبان مشترك، دين و مذهب مشترى، عقايد و ارزشهاى مشترى، لباس مشترى و غذاى خوب

شهرهاى مذهبى، جاذبههاى تاريخى و امكانات تفريحى

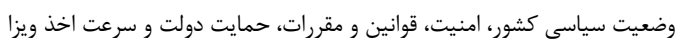

جنس بيمار، سن بيمار، تحصيلات بيمار و نزديكى محل سكونت بيمار

شغل بيمار، درامد بيمار و طبقه اقتصادى بيمار

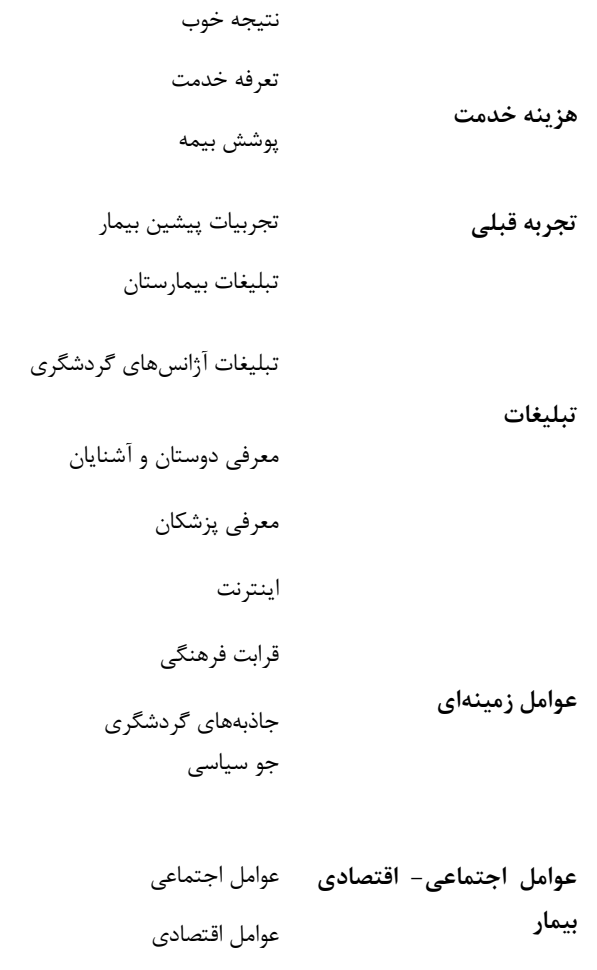

نتيجه خوب

تعرفه خدمت

بوش بيمه

تجربيات پيشين بيمار 
بسترى و \&4ع مصاحبه فردى با بيماران سريايى (در كل • بr بيمار)،

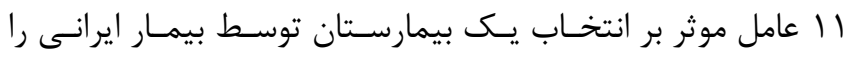

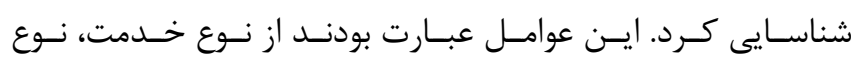

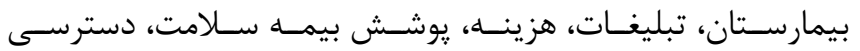

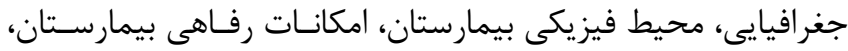

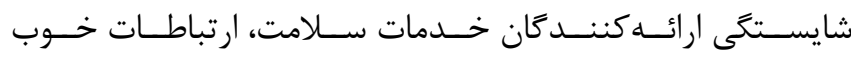

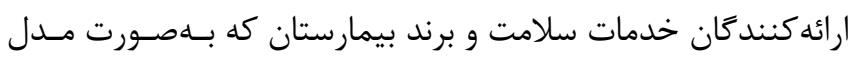

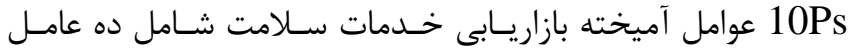

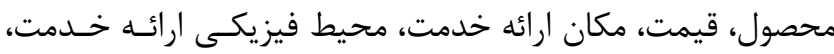
ارائه كنند

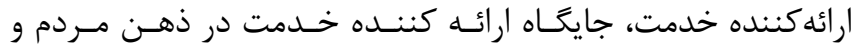

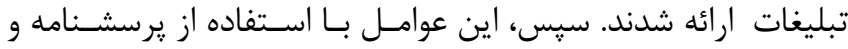

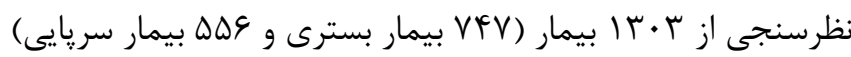
مورد بررسى قرار كرفت. توصيه يزشكان، مهارت و تخصص يزشكان،

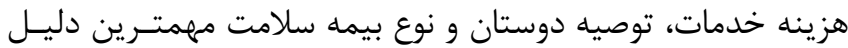

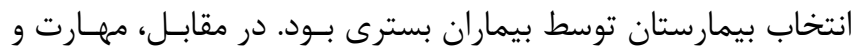
تخصص يزشكان، نوع بيمه سلامت، هزينه خدمات سلامت و توصيه

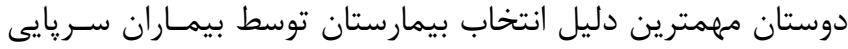

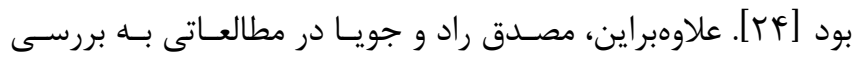

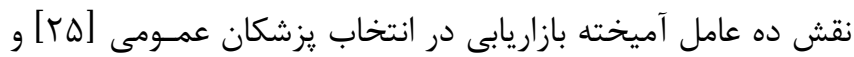

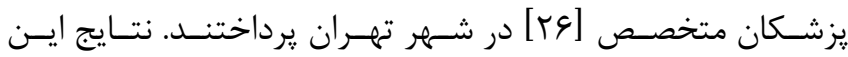

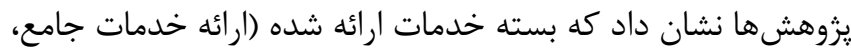

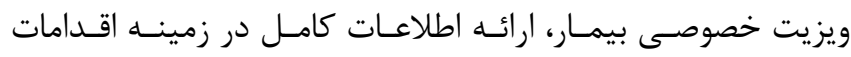

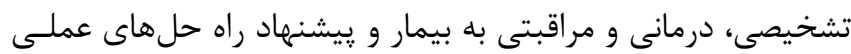

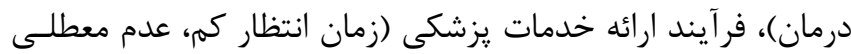

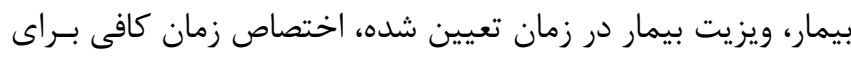

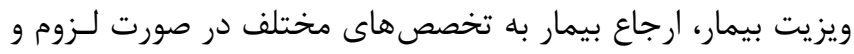

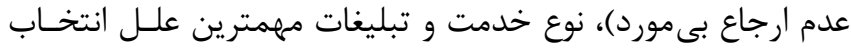

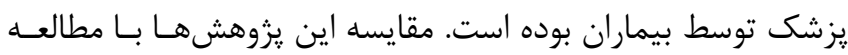

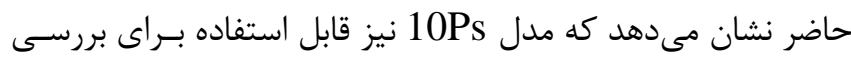

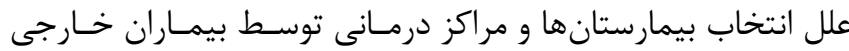

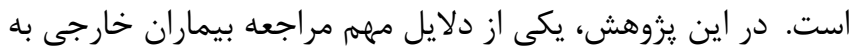

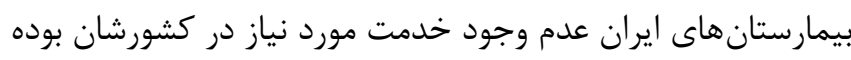

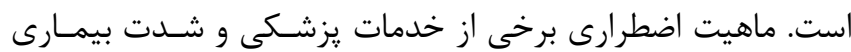

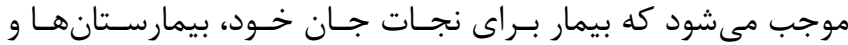

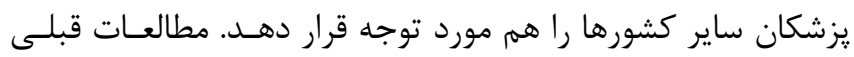

دوستان، آشنايان و يزشـكان و اينترنـت)، عوامـل زمينــاى (قرابـت فرهنكى، جاذبههاى كردشكرى و جو سياسى) و عوامـل اجتمـاعى و

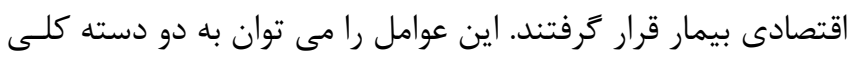

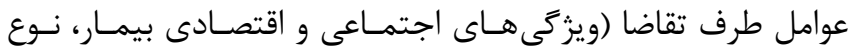
خدمت و تجربه قبلى بيمار ) و عوامل طرف عرضه (كيفيت و هزينسه

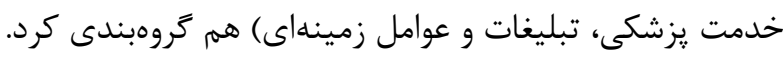

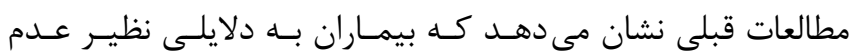

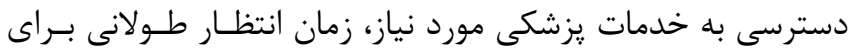

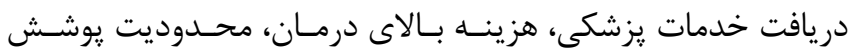

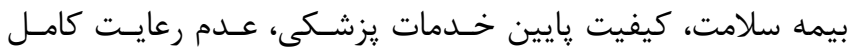

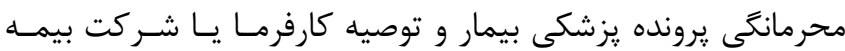

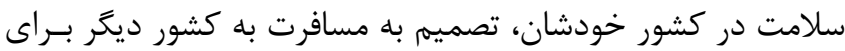

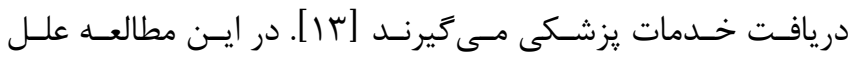

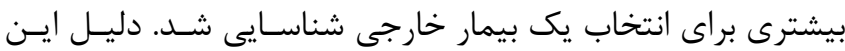

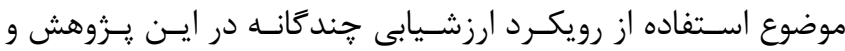

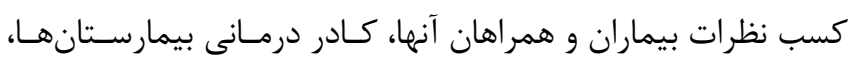
كارشناسان و اساتيد خبره حوزه گَردشكرى سلامت بودان بيماران بيشتر ترجيح مى دهند كه خدمات يزشكى و جراحسى مـورد

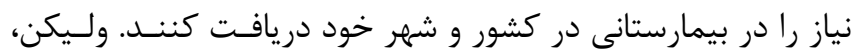

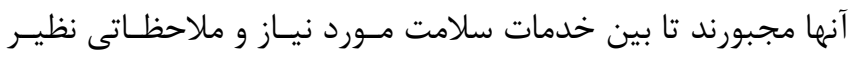

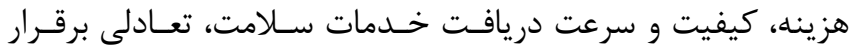

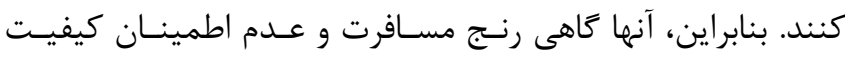

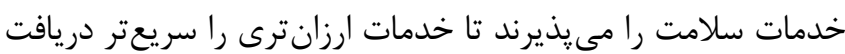

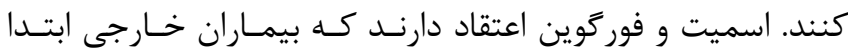
كشور مقصد و سيس، بيمارستان و مركـز درمـانى را بـراى دريافت

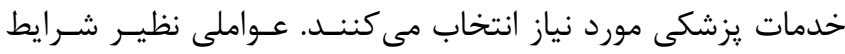
اقتصادى، جو سياسى و سياستهاى نظارتى در انتخاب كشور مقصد

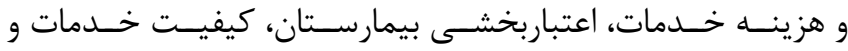

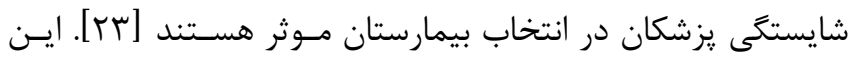

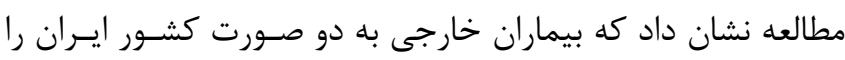

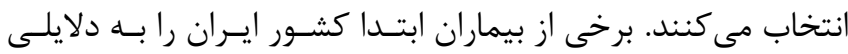

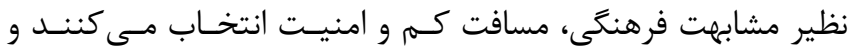

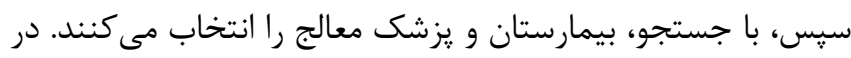

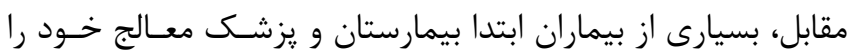

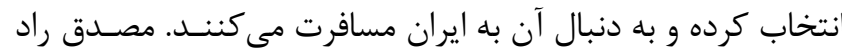

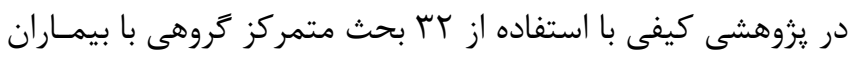


بهداشتى و درمانى مىرسد. كيفيت ارزشيابى شـناختى مشـترى در

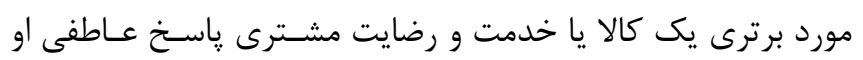

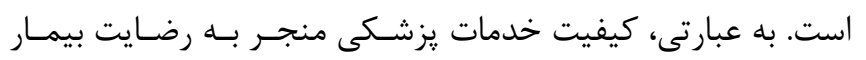

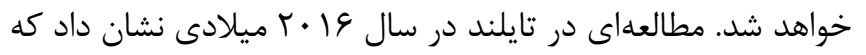

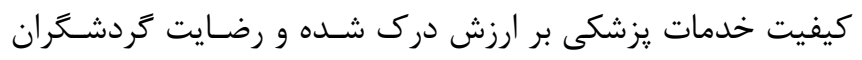

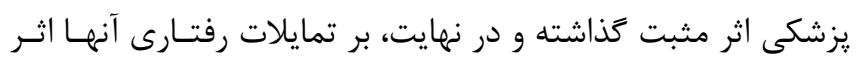

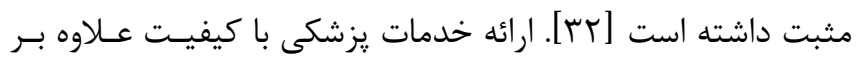

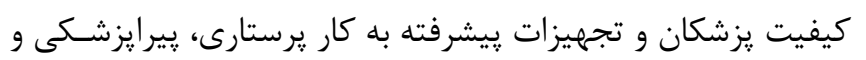
يشتيبانى با كيفيت هم نياز دارد.

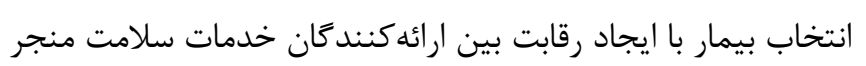

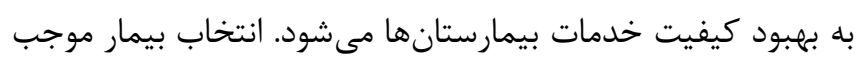

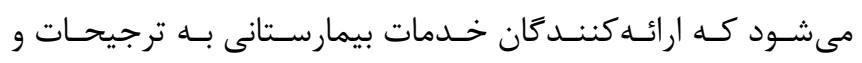

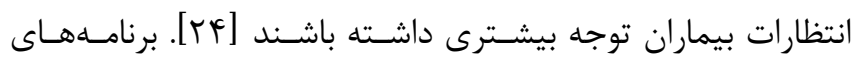

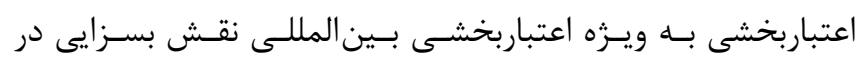

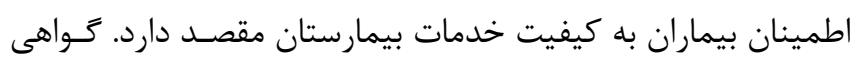

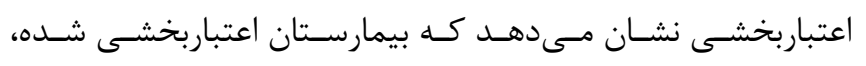

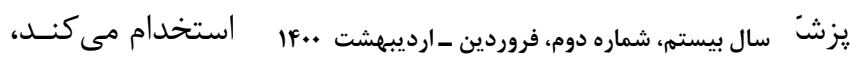

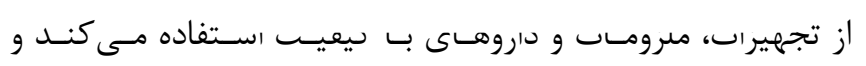

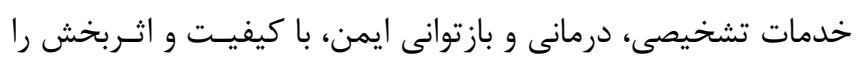

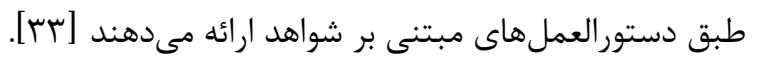

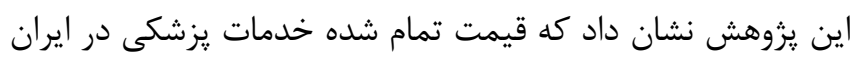

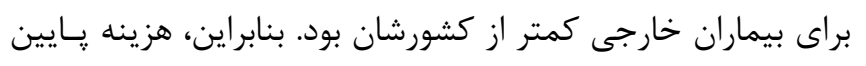

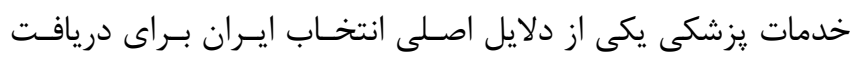

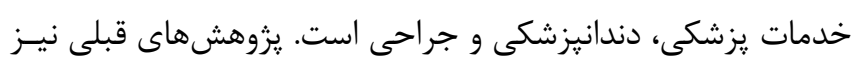

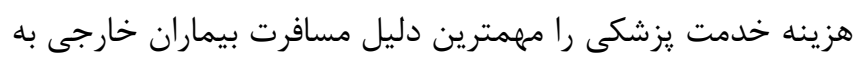

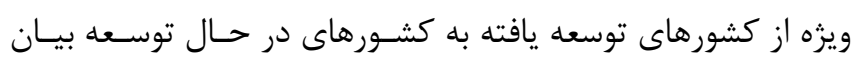

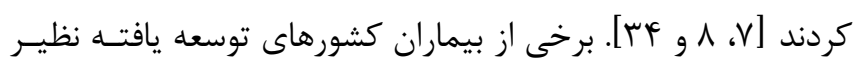

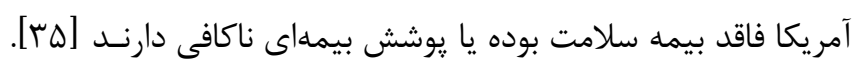

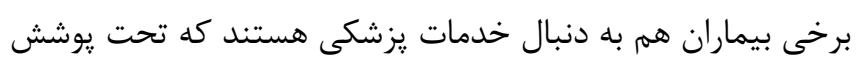

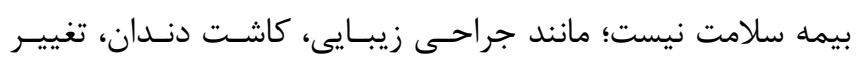

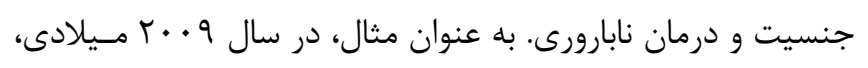

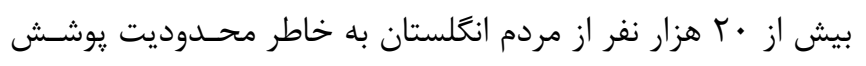

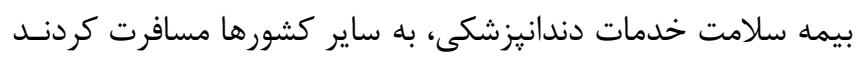

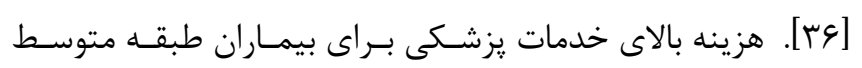

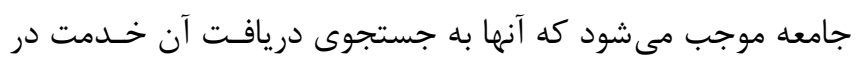

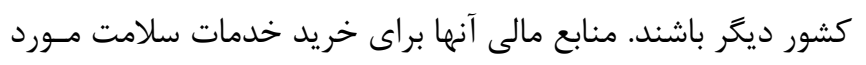

هم نشان داد كه بيماران كاهى اوقات براى دريافت خـدماتى كـهـ در

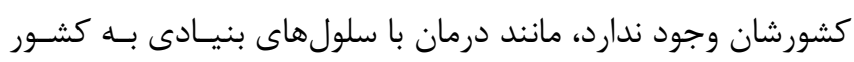

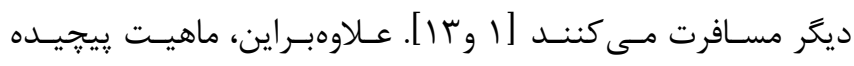

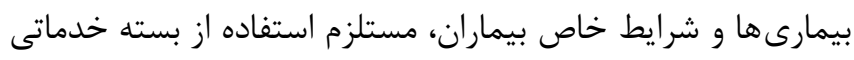

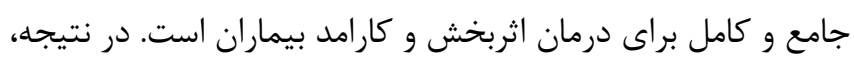

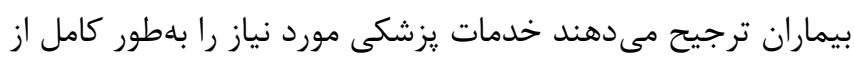

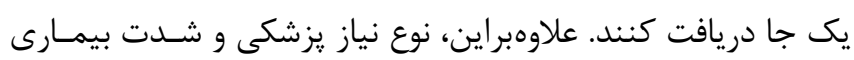

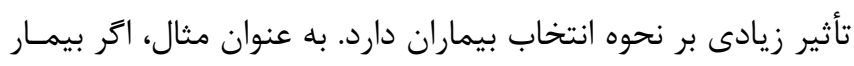

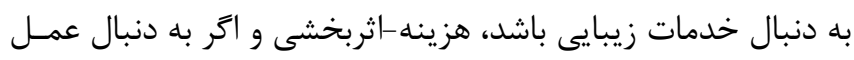

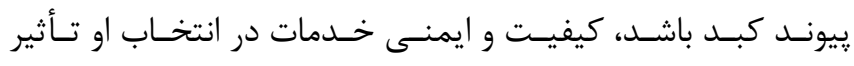

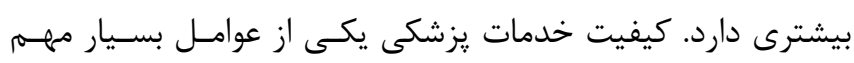

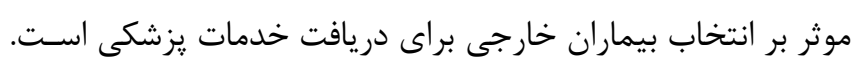

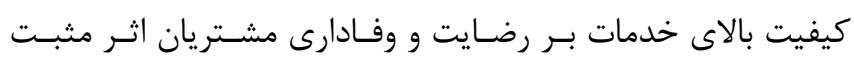

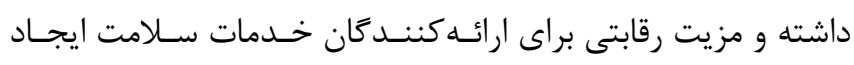

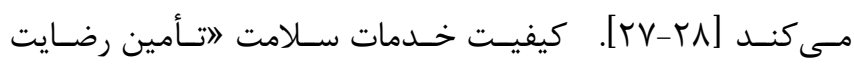

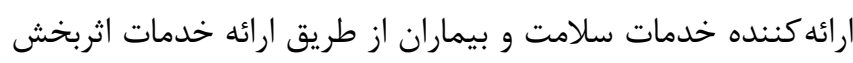

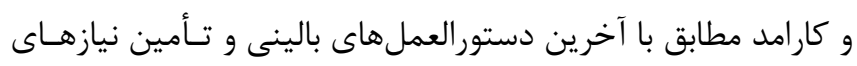

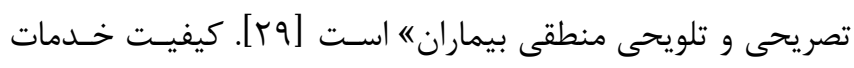

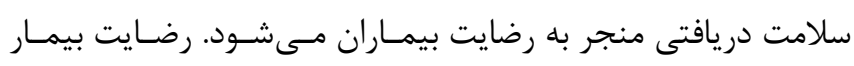

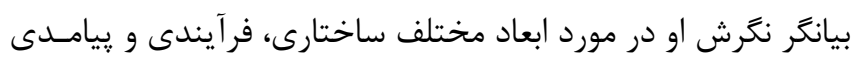

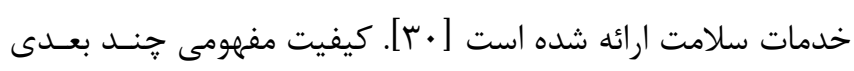

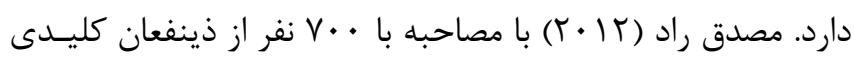

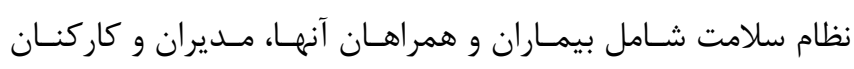

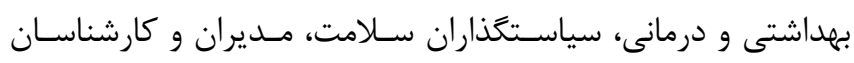

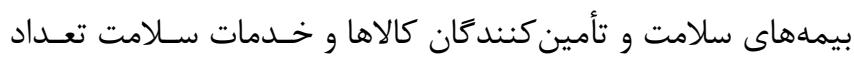

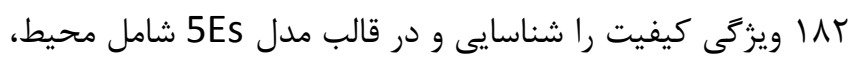

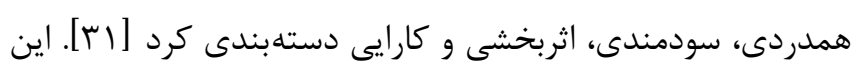

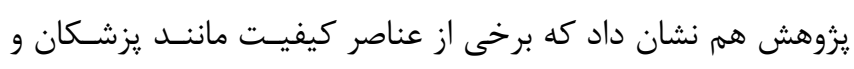

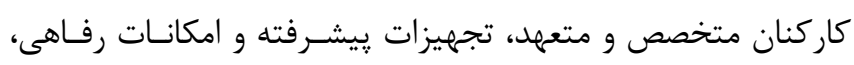

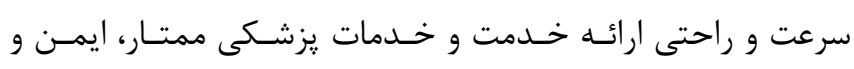

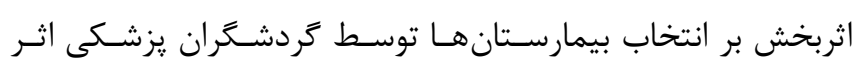

مى مذارند.

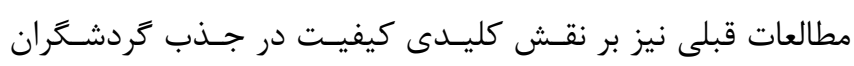

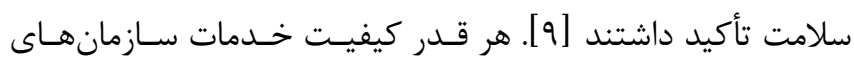

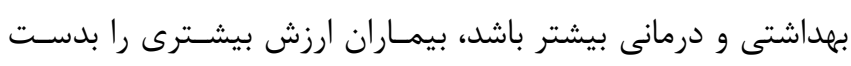

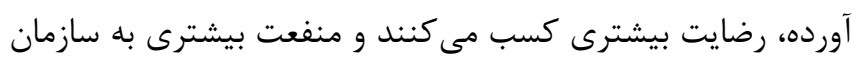


طبيعى نكخران سفر به خارج از كشور براى درمان هسـتند. بنـابراين،

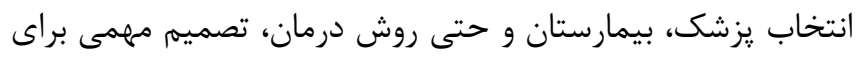

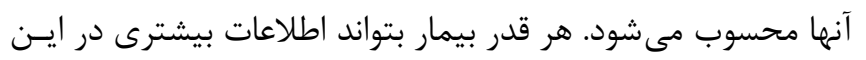

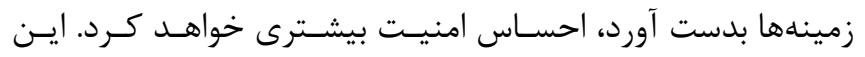

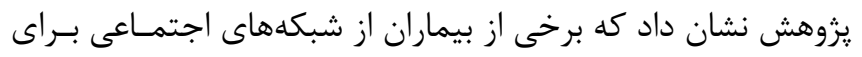

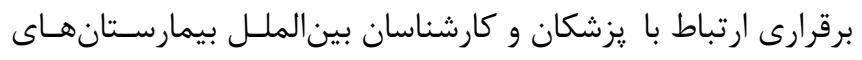

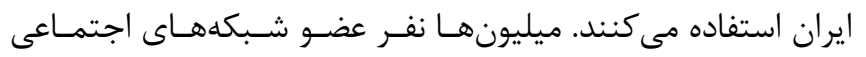

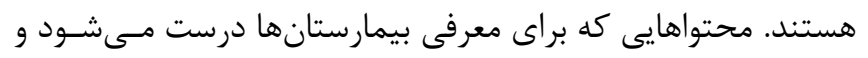

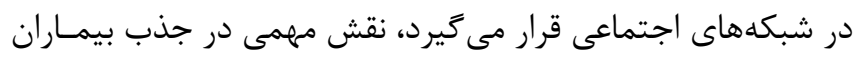

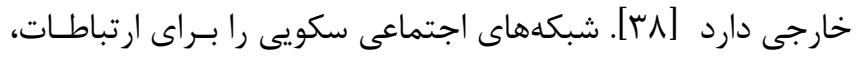

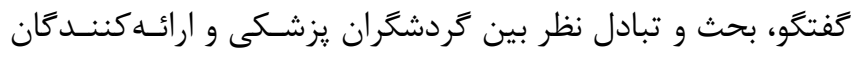

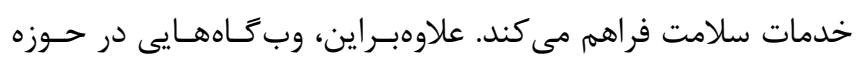

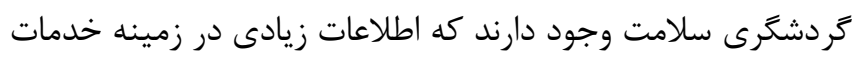

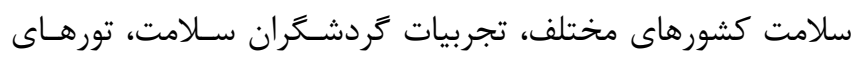

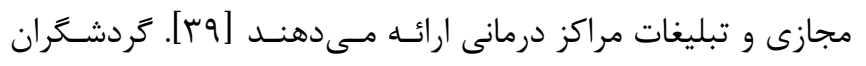

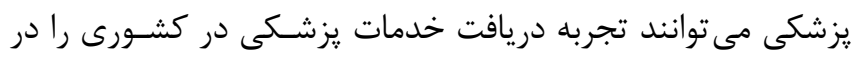

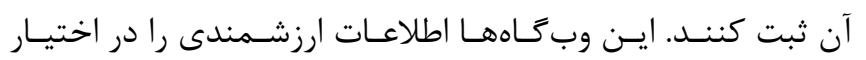

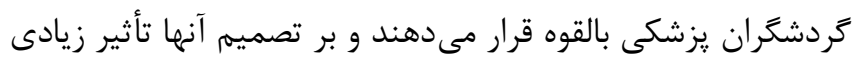

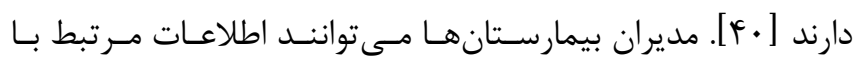

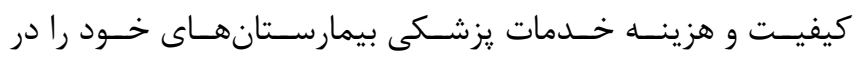

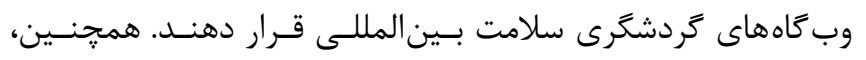

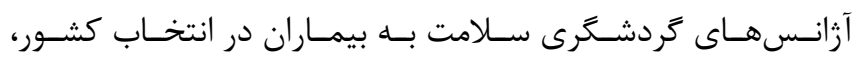

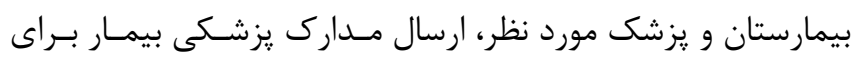

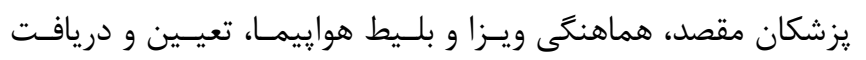

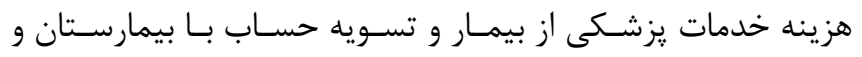

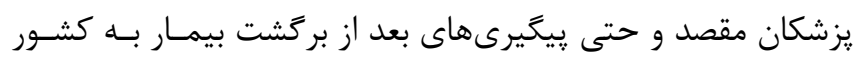

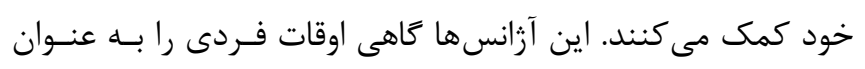

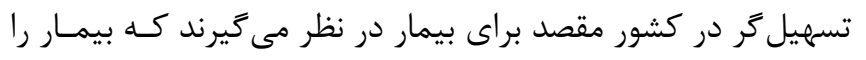

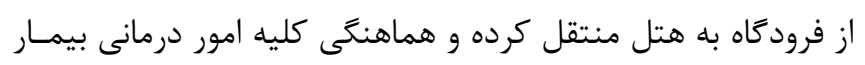

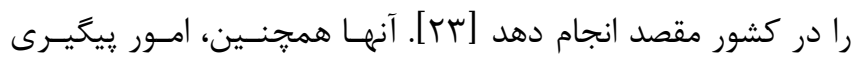

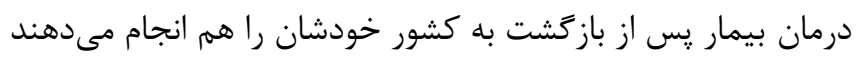

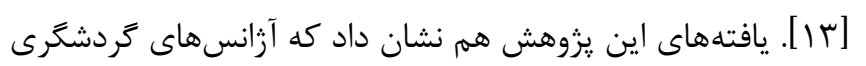

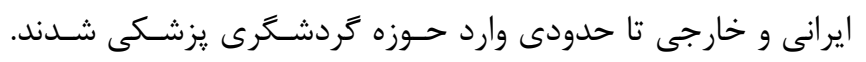

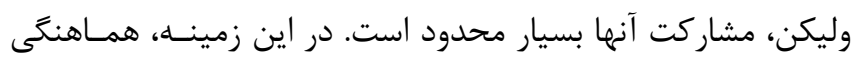

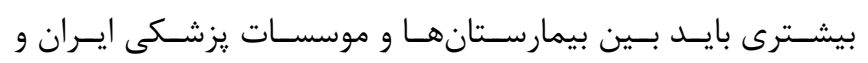
آزانسهاى كردشَّرى ايجاد شود.
نياز در كشور خودشان محدود بوده ولى، براى خريد اين خدمات در

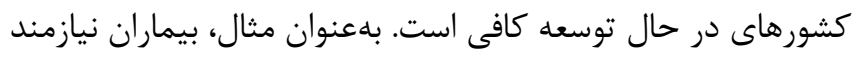

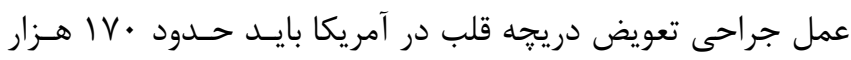

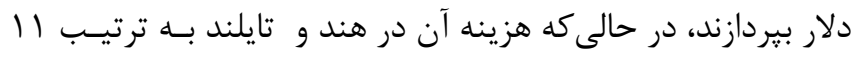

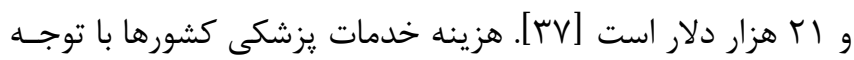

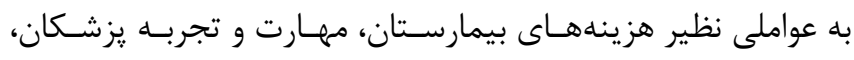

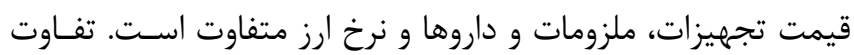

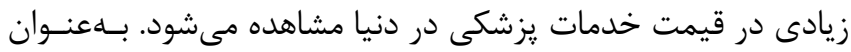

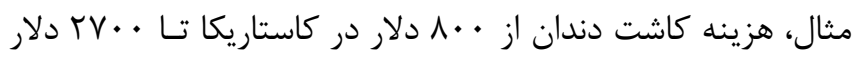

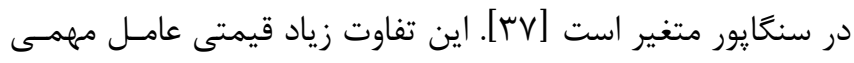

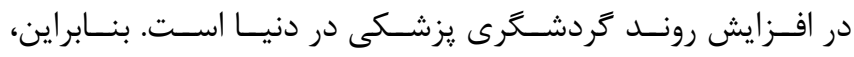

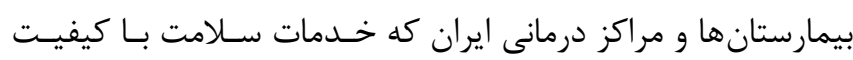

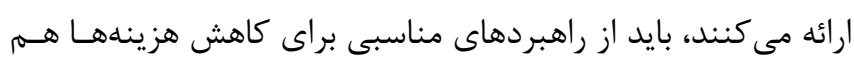

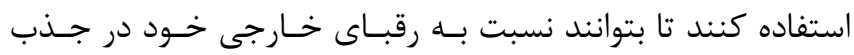

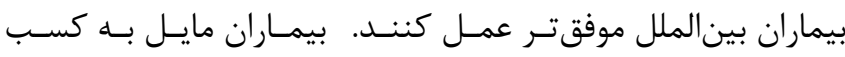

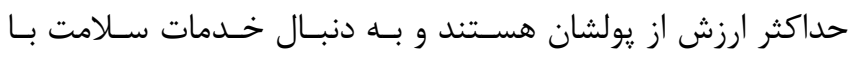

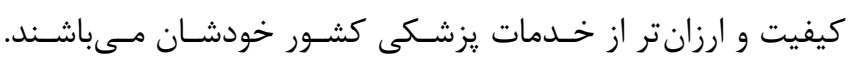

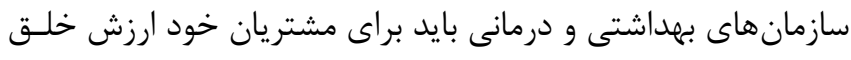

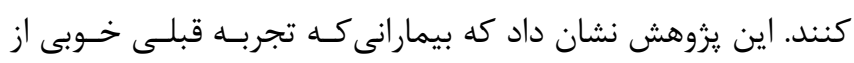

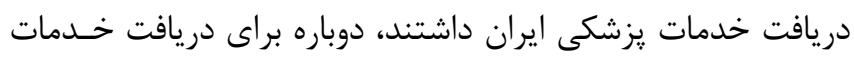

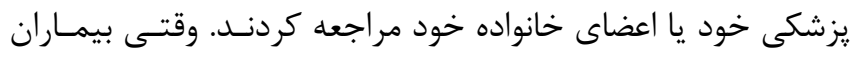

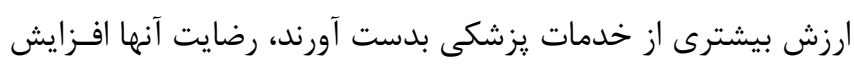

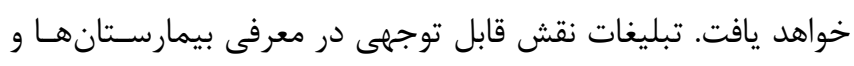

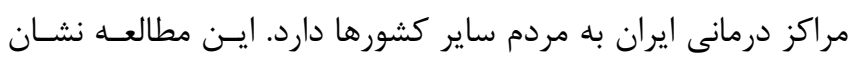

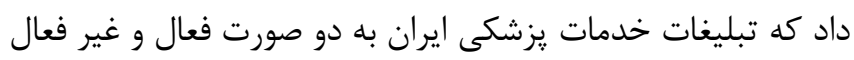

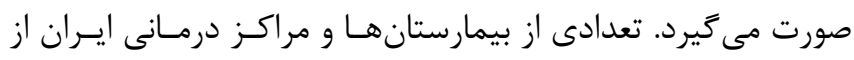

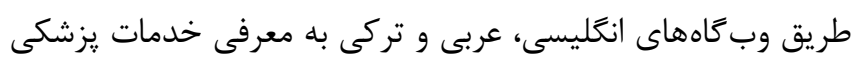

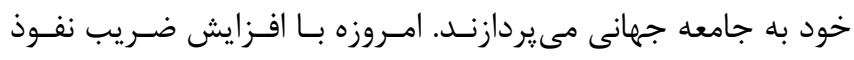

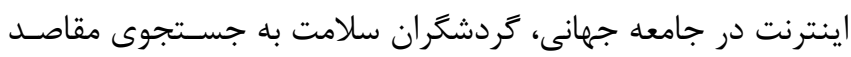

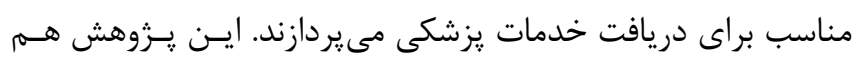

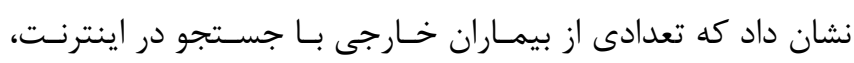

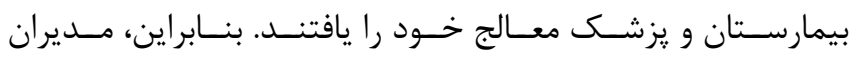

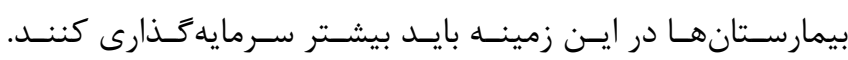

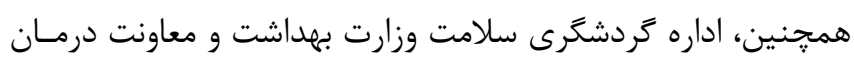

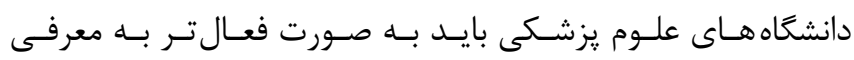

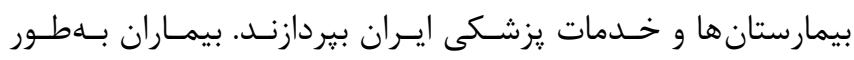




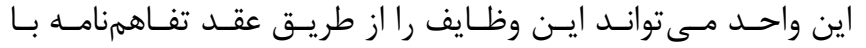

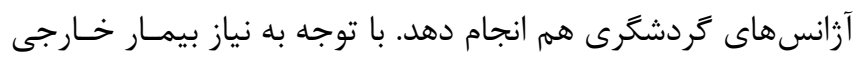

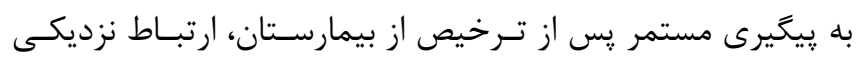

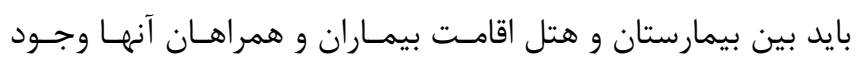

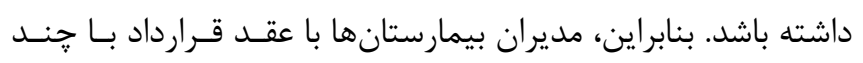

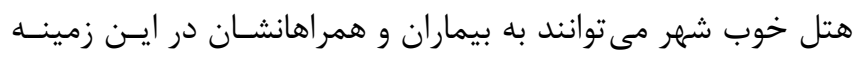
كمك كنند و نكرانى آنها را كاهش دون دهند عوامل اجتماعى و اقتصادى بيمار مانند جنسـيت، سـن، تحصـيلات،

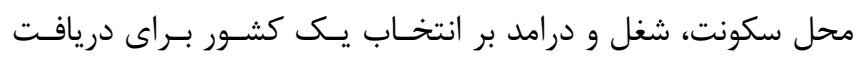

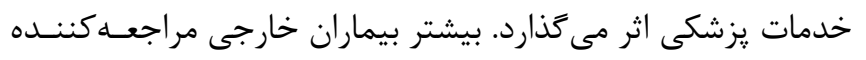

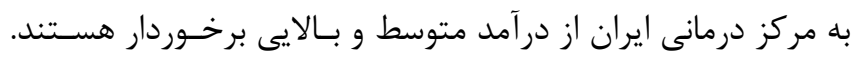

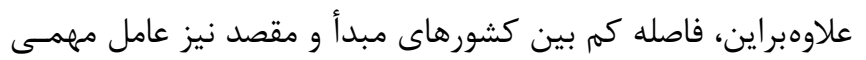

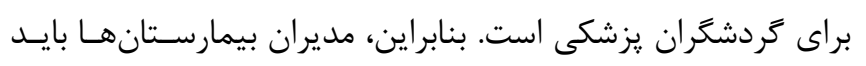

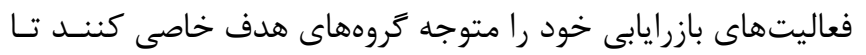
به نتيجه بهترى دست يابند.

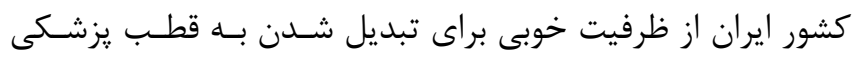

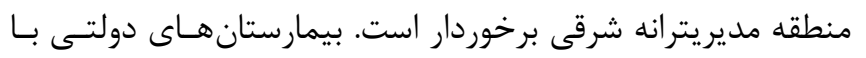

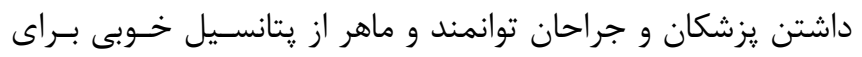

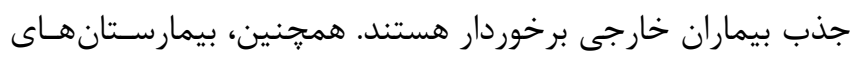

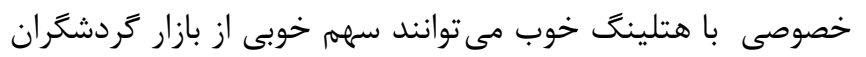

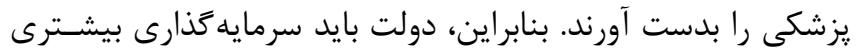

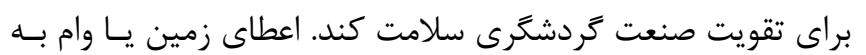

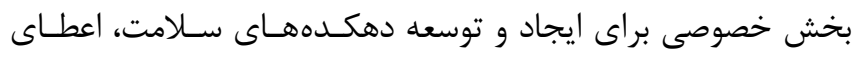

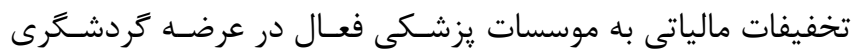

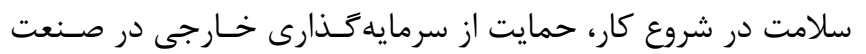

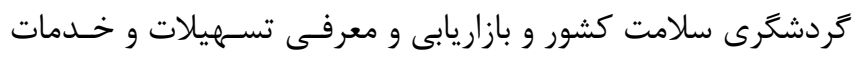

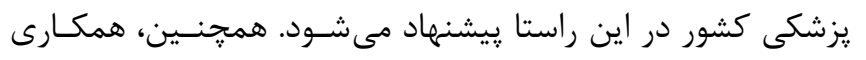

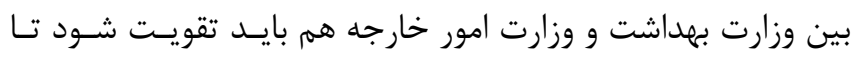

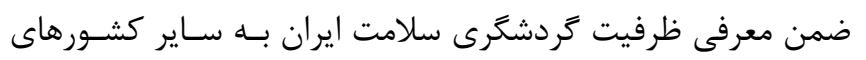

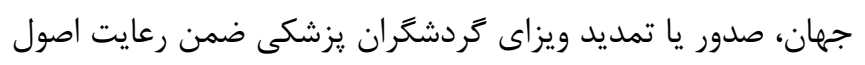
امنيتى، تسهيل و تسريع شود.

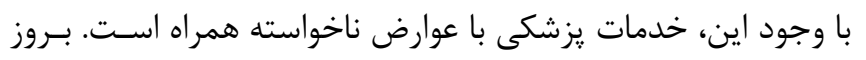

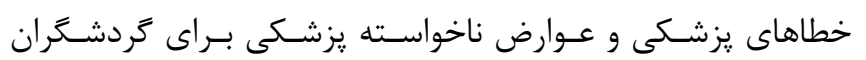

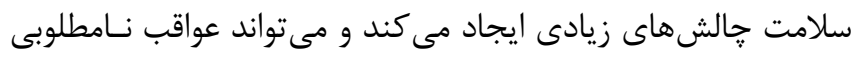
حتى براى دستخاه دييلماسى كشور داشـته باشـد. بنـابراين، تـلاش

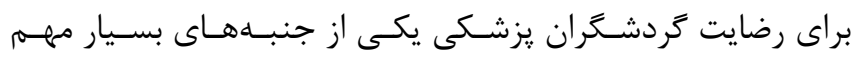

اين يزوهش نشان داد كـهـ برخى از يزشـان كشــورهاى همسـايه،

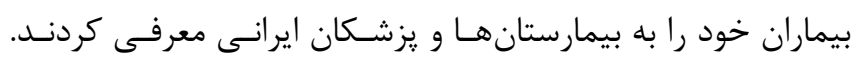

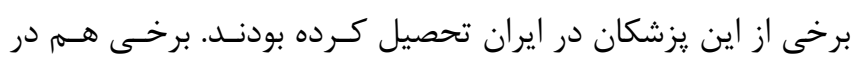

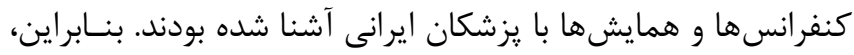

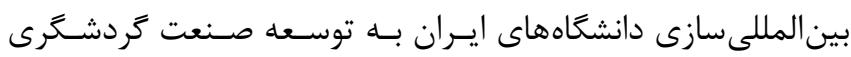

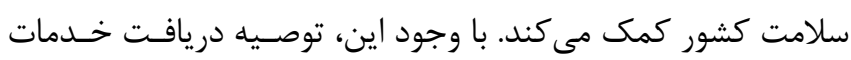

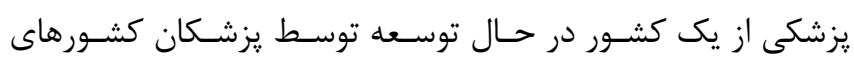

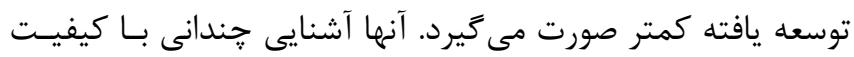

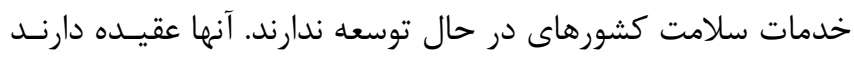

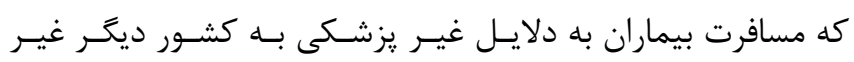

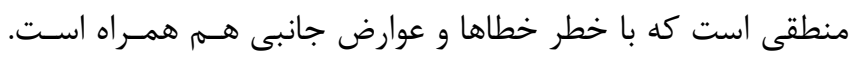

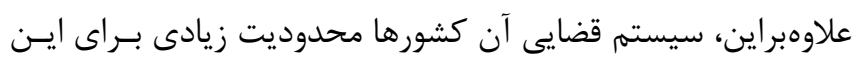

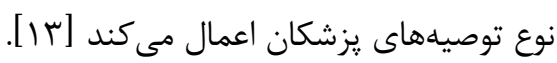

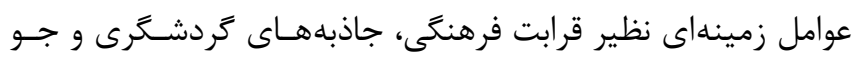

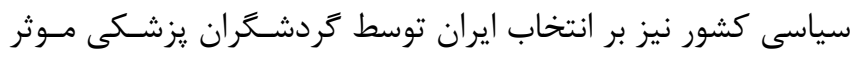

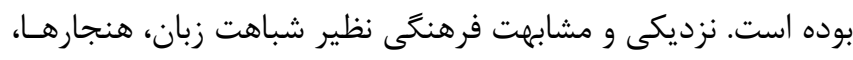

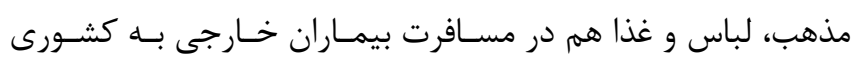

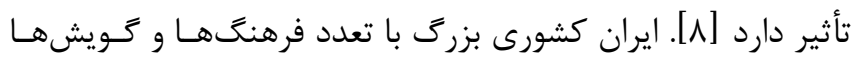

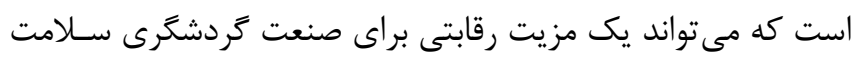

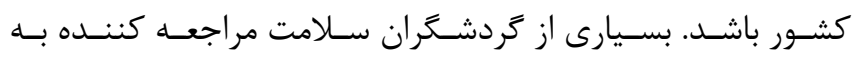

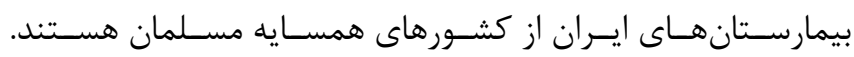

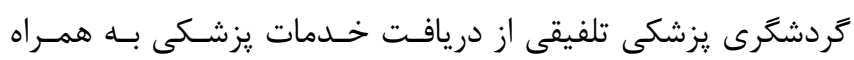

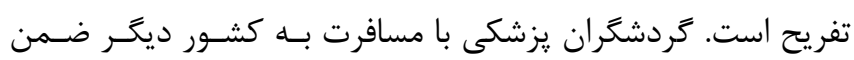

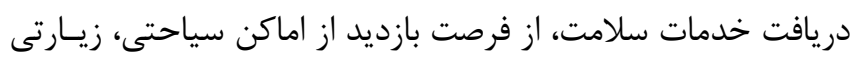

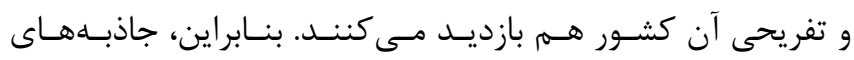

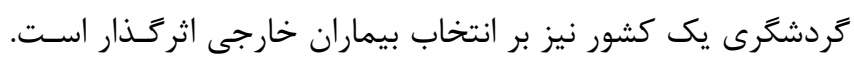

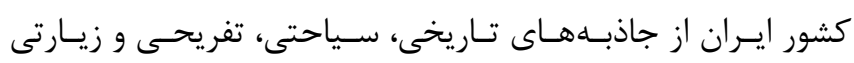

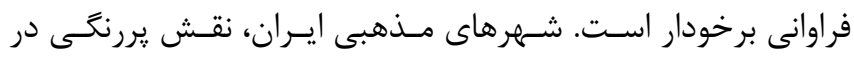

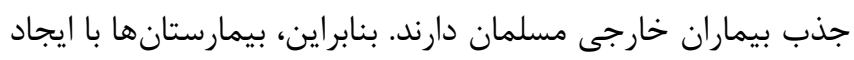

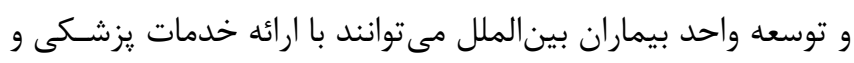

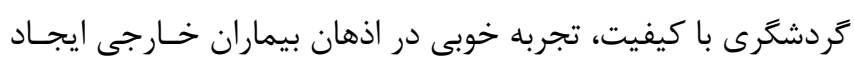

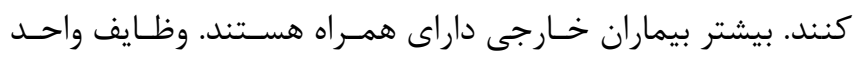

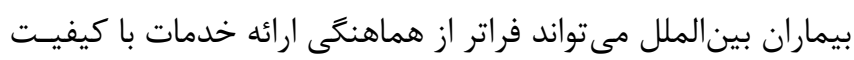

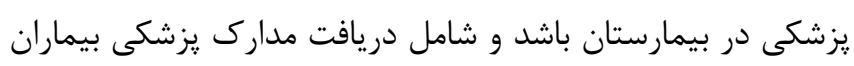

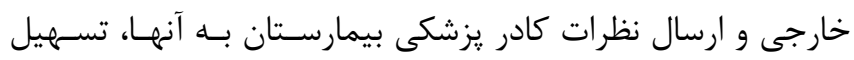

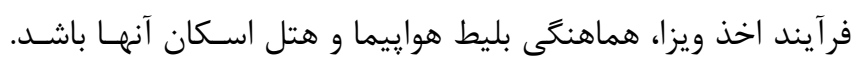




\begin{abstract}
سمه نويسند
على محمد مصدقراد: طراحسى يـرزوهش، تحليـل دادهـــا و نحــارش

مقاله

مهر كان صادقى: جمعآورى دادهها، تحليل دادهها و نعارش مقاله

تشكر و قدردانى مادى جمعان

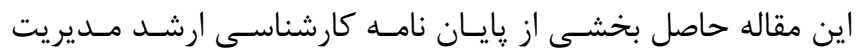

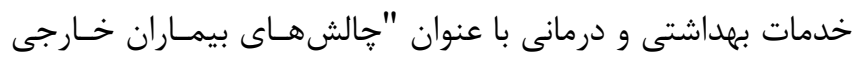

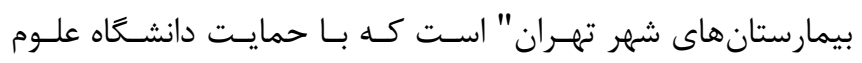

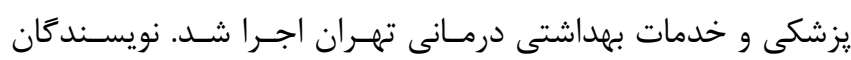

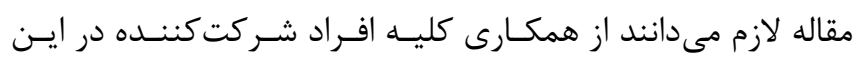

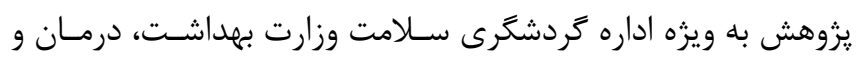

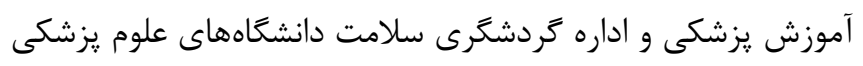

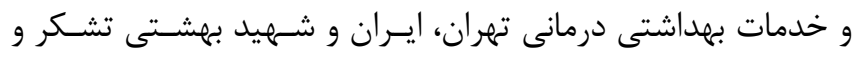

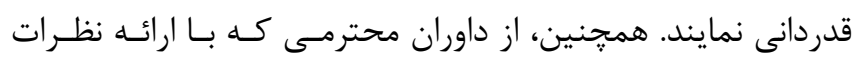

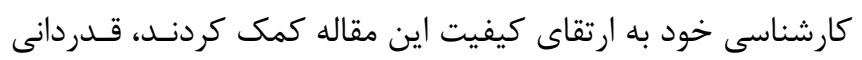

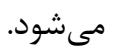

\section{منابع}

1. Connell J. Medical tourism: Sea, sun, sand and surgery. Tourism management 2006;27:1093-100

2. Heung VC, Kucukusta D, Song H. A conceptual model of medical tourism: Implications for future research. Journal of Travel \& Tourism Marketing 2010; 30; 27:236-51

3. Grand View Research. Medical tourism market size, share \& trends analysis report by country and segment forecasts, 2020-2027. Market Analysis Report. 2020. Available at https://www.grandviewresearch.com/industryanalysis/medical-tourism-market [Access date 2021/02/27]

4. Cham TH, Lim YM, Sia BC, Cheah JH, Ting H. Medical tourism destination image and its relationship with the intention to revisit: A study of Chinese medical tourists in Malaysia. Journal of China Tourism Research 2020:1-29

5. Milstein A, Smith M. America's new refugees: seeking affordable surgery offshore. New England Journal of Medicine 2006;355:1637-40

6. Mattoo A, Rathindran R. How health insurance inhibits trade in health care. Health Affairs 2006; 25:358-68

7. Abd Manaf NH, Hussin H, Kassim PN, Alavi R, Dahari Z. Country perspective on medical tourism: the Malaysian experience. Leadership in Health Services 2015; 28: 43-56
كَرشخرى سلامت است كه بايد مورد توجه جـدى سياسـتخذاران و

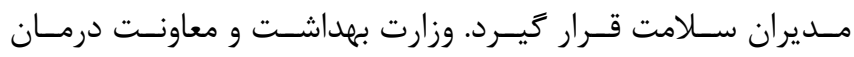

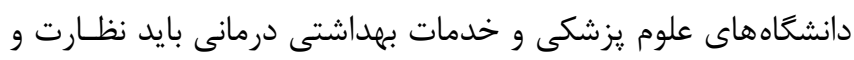

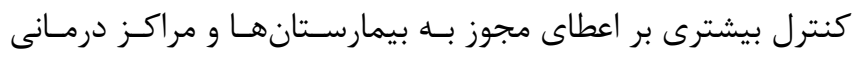

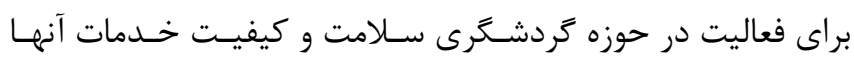

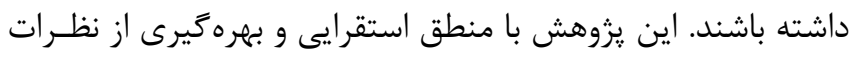

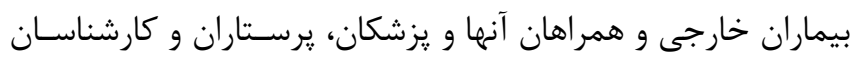

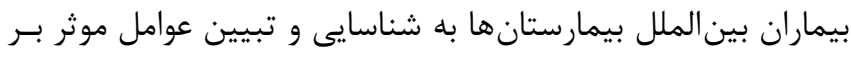

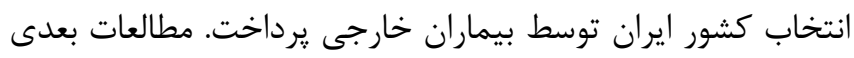

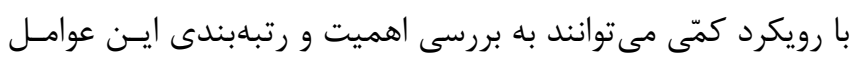

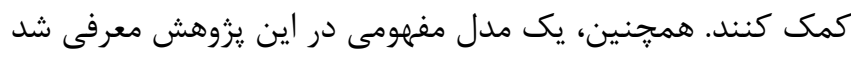

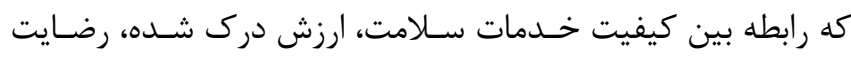

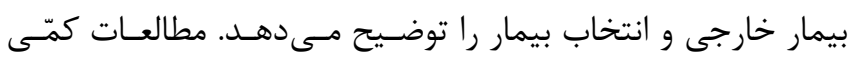

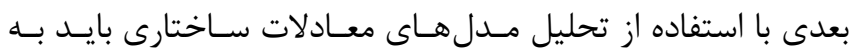
آزمون اين مدل نظرى بيردازند.

8. Yu JY, Ko TG. A cross-cultural study of perceptions of medical tourism among Chinese, Japanese and Korean tourists in Korea. Tourism management 2012;33:80-8

9. $\mathrm{Lu} \mathrm{HY}, \mathrm{Wu} \mathrm{WY}$, Chen SH. Influences on the perceived value of medical travel: the moderating roles of risk attitude, self-esteem and word-of-mouth. Current Issues in Tourism 2016;19:477-91

10. Taheri B, Chalmers D, Wilson J, Arshed N. Would you really recommend it? Antecedents of word-ofmouth in medical tourism. Tourism Management 2020;83:104209

11.Wang HY. Value as a medical tourism driver. Managing Service Quality: An International Journal 2012; 22: 465-491

12. Crooks VA, Turner L, Snyder J, Johnston R, Kingsbury P. Promoting medical tourism to India: Messages, images, and the marketing of international patient travel. Social Science \& Medicine 2011;72:726-32

13. Horowitz MD \& Rosensweig JA. Medical tourismhealth care in the global economy. Physician executive 2007;33:28-30

14. Wongkit M, McKercher B. Desired attributes of medical treatment and medical service providers: A 
case study of medical tourism in Thailand. Journal of Travel \& Tourism Marketing 2016;33:14-27

15. Patients Beyond Borders. Quick Facts about Medical Tourism. Available at: https://www.patientsbeyondborders.com/media [Ac cess date 2019/11/12]

16. Statista. Top medical tourism countries by total index rating worldwide 2020.Available at https://www.statista.com/statistics/889983/top-

medical-tourism-countries-of-destination-by-total-

index-rating/ [Access date 2021/02/27]

17.Izadi M, Ayoobian A, Nasiri T, Joneidi N, Fazel M, Hosseinpourfard M. Situation of health tourism in Iran opportunity or threat. Iranian Journal of Military Medicine 2012;14:69-75

18. Hadian M, Jabbari A, Mousavi SH, Sheikhbardsiri H. Medical tourism development: A systematic review of economic aspects. International Journal of Healthcare Management 2019:1-7

19. Momeni K, Janati A, Imani A, Khodayari-Zarnaq $\mathrm{R}$. Barriers to the development of medical tourism in East Azerbaijan province, Iran: A qualitative study. Tourism Management 2018;69:307-16

20. Husserl E. Phenomenology and the foundations of the sciences. Springer Science \& Business Media: Uk, 2001

21. Maggs-Rapport F. Combining methodological approaches in research: ethnography and interpretive phenomenology. Journal of Advanced Nursing 2000; 31: 219-225

22. Braun V, Clarke V. Using thematic analysis in psychology. Qualitative research in psychology. Qualitative Research in Psychology 2006; 3:77-101 23. Smith PC, Forgione DA. Global outsourcing of healthcare: a medical tourism decision model. Journal of Information Technology Case and Application Research 2007;9:19-30

24. Mosadeghrad AM, Patient choice of a hospital: implications for health policy and management, International Journal of Health Care Quality Assurance 2014; 27: 152-164

25. Mosadeghrad AM, \& Jooya, T. Factors influencing patient choice of a medical doctor, Medical Council Journal 2015; 32: 337-347. [in Persian]

26. Mosadeghrad AM, \& Jooya T. Factors influencing patient choice of a medical consultant in Tehran. Razi Journal of Medical Sciences 2017; 24: 62-72 [in Persian]
27.Lee WI, Chen CW, Chen TH, Chen CY. The relationship between consumer orientation, service value, medical care service quality and patient satisfaction: The case of a medical center in Southern Taiwan. African Journal of Business Management 2010;4:448-58

28. Mosadeghrad AM, Ferlie E. Total quality management in healthcare. Management innovations for healthcare organizations: adopt, abandon or adapt. Routledge: New York, 2016

29. Mosadeghrad AM. Healthcare service quality: Towards a broad definition. International Journal of Health Care Quality Assurance 2013; 26: 203-219

30. Mosadeghrad AM, Ashrafi E. The impact of quality management on patient satisfaction in a hospital: brief report. Tehran University Medical Journal 2017;75:228-34 [in Persian]

31. Mosadeghrad AM. A conceptual framework for quality of care. Mat Soc Med 2012; 24: 251-261

32. Prajitmutita LM, Perényi Á, Prentice C. Quality, value?-Insights into medical tourists' attitudes and behaviors. Journal of Retailing and Consumer Services 2016;31:207-16

33. Mosadeghrad AM. Hospital accreditation: The good, the bad, and the ugly, International Journal of Healthcare Management 2020:1-5

34. Marlowe J, Sullivan P. Medical tourism: the ultimate outsourcing. Human Resource Planning 2007;30:8-10

35. Mossialos E, Osborn R. \& Sarnak D. International profiles of health care systems. $1^{\text {st }}$ Edition, The Commonwealth Fund: New York, 2017

36. Knight L. Guide the patient: are you a savvy patient? Medica Tourism 2010;6:79

37. Medical Tourism Association. International Medical Treatment Prices. Retrieved from https://www.medicaltourism.com/compare-prices [Access date 28/02/2021].

38. Zeng B, Gerritsen R. What do we know about social media in tourism? A review. Tourism management perspectives 2014;10:27-36

39. Lunt N, Carrera P. Systematic review of web sites for prospective medical tourists. Tourism

Review2011; 66: 57-67

40. Lai LS, To WM. Content analysis of social media: A grounded theory approach. Journal of Electronic Commerce Research 2015;16:138 